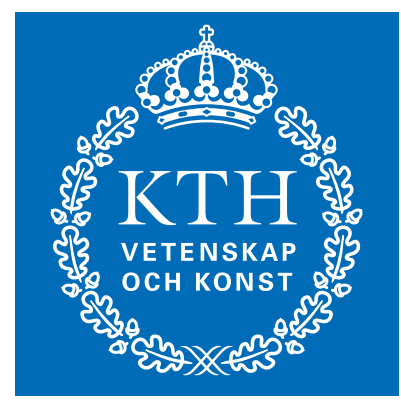

ROYAL INSTITUTE

OF TECHNOLOGY

\title{
Neuroproteomic profiling of human body fluids
}

Anna Häggmark

Doctoral Thesis

Kungliga Tekniska Högskolan, KTH

Royal Institute of Technology

School of Biotechnology

Stockholm 2015 
(c) Anna Häggmark 2015

Affinity Proteomics

Science for Life Laboratory

Division of Proteomics and Nanobiotechnology

School of Biotechnology

KTH, Royal Institute of Technology

Tomtebodavägen 23A

17165 Solna, Sweden

ISBN 978-91-7595-402-8

TRITA-BIO Report 2015:2

ISSN 1654-2312

Printed by US-AB

Cover illustration: Annie Söder 
"The seat of the soul and the control of voluntary movement - in fact, of nervous functions in general, - are to be sought in the heart. The brain is an organ of minor importance, perhaps necessary to cool the blood." 



\section{Abstract}

This thesis provides results from affinity based studies where human body fluids were profiled to find markers for neurological diseases. Both proteins and autoantibodies were analysed using microarray technologies that can profile hundreds of analytes and hundreds of samples in parallel using small sample volumes. A central element in this work was to develop and apply new methods to study cerebrospinal fluid (CSF), which is the fluid in direct contact with the brain. CSF contains proteins reflecting the physiological state of the central nervous system and therefore offers a unique insight into proteins associated to neurological disorders. As a complement to CSF, bloodderived samples such as serum and plasma, were also investigated as these represent potential sources of disease related proteins. The work presented here summarises the development of assay protocols to study protein and autoantibodies in CSF and blood using planar and bead-based microarrays.

In Paper I, an antibody-based protocol was developed to enable multiplexed protein profiling in CSF. The protocol was then applied for a first analysis within multiple sclerosis (MS) patients. In Paper II, the results were further evaluated in additional CSF as well as plasma samples. Based on the CSF analysis we found two proteins associated to MS; GAP43, a protein related to disease progression and SERPINA3, a protein involved in inflammation. In addition, four other proteins; IRF8, METTL14, IL7 and SLC30A7, were found to have altered plasma levels between the patient groups. The expression of these proteins were further investigated by immunofluorescent staining of human brain tissue, revealing differential localisation of proteins in diseased and healthy brain. In Paper III, a study on extensive protein profiling of plasma in the context of another neurodegenerative disorder, amyotrophic lateral sclerosis (ALS), is described. The levels of three proteins, namely NEFM, RGS18 and SCL25A20, were found to be elevated in ALS patients compared to controls. Among these, NEFM also indicated association to disease subtype as the levels were elevated in patients with definite compared to suspected diagnosis.

In addition to antibodies, we also utilised antigens on microarrays to screen for the presence of autoantibodies in body fluids. In Paper IV, a strategy for this analysis was developed using protein fragments and two types of microarrays. This strategy was then applied for profiling of the autoantibody repertoire of MS patients, revealing 51 protein fragments with potential disease relevance. Interestingly, comparison of plasma and CSF samples obtained from the same patients indicated high concordance of antibodies between the two body fluids. In Paper V, a similar strategy was applied to narcolepsy, another neurological disorder. Our investigation of antibodies in serum revealed higher reactivity towards METTL22, NT5C1A and TMEM134 compared to controls in two independent sample materials.

In conclusion, the presented work constitutes a framework of proteomic assays for enhanced exploration of proteins and autoantibodies in neuroscience. Moreover, we have reported identification of several potential disease markers to be further investigated within neurological disorders. 


\section{Populärvetenskaplig sammanfattning}

Inom medicinsk forskning pågår mycket arbete för att öka förståelsen för de sjukdomar som drabbar oss människor. Varför uppstår de, vad händer i kroppen när man blir sjuk och hur kan vi diagnosticera, behandla och bota dem? För forskning inom neurologiska sjukdomar står hjärnan i centrum. Hjärnan är ett organ som bland annat koordinerar våra rörelser, lagrar minnen och skapar tankar och känslor. Den omges av en vätska som kallas ryggmärgsvätska som fungerar som stötdämpare och har i uppgift att transportera näringsämnen till, och restprodukter från, hjärnan. Ryggmärgsvätska innehåller också proteiner, de molekyler som utgör våra biologiska byggstenar. Proteinerna är mycket viktiga för att kroppens alla celler, vävnader och organ ska fungera normalt. När kroppen inte fungerar som den ska, till exempel vid sjukdom, kan proteiner ge viktig information om vad som är fel. På samma sätt kan upptäckten av ett protein som inte beter sig normalt ge nya ledtrådar till varför sjukdomar uppstår. Min forskning har haft som mål att bidra till ökad kunskap inom neurologiska sjukdomar genom att utveckla analysmetoder för undersökning av proteiner i blod och ryggmärgsvätska från sjuka och friska människor.

Det finns en speciell familj proteiner som kallas för antikroppar och som fungerar som kroppens naturliga skydd mot infektioner. Dessa antikroppar har förmågan att känna igen och fästa sig vid olika molekyler och kan på så sätt presentera okända substanser för kroppens immunförsvar. Denna avhandling är baserad på analysmetoder där antikroppars förmåga att känna igen andra proteiner har utnyttjats för forskning. Arbetet är en del av Human Protein Atlas, ett stort projekt med målet att tillverka antikroppar som kan känna igen människans alla proteiner. Dessa antikroppar används sedan för att kartlägga var i kroppen våra proteiner finns och vad som skiljer olika vävnader och organ från varandra.

I tre av de presenterade forskningsprojekten användes antikropparna från proteinatlasen för att mäta proteiner i ryggmärgsvätska och blod från patienter med neurologiska sjukdomar. Första steget var att utarbeta en ny metod för att analysera hundratals proteiner samtidigt i ryggmärgsvätska (Paper I). När vi sedan undersökte prover från multipel skleros (MS) patienter hittade vi sex intressanta proteiner, två i ryggmärgsvätska och fyra i blod, som speglade sjukdomen (Paper II). I en liknande studie inom amyotrofisk lateral skleros (ALS) hittade vi tre sjukdomsrelaterade proteiner i blod (Paper III) och vi arbetar nu för att mer i detalj förstå dessa proteiners inverkan på sjukdomsförloppet.

Ibland bildas antikroppar som misstar kroppens egna proteiner för främmande och det är genom sådana antikroppar som autoimmuna sjukdomar kan uppstå. De två sista artiklarna beskriver hur vi undersökte blod och ryggmärgsvätska för att upptäcka antikroppar som känner igen mänskliga proteiner, så kallade autoantikroppar. I båda studierna, den ena inom MS (Paper IV) och den andra inom narkolepsi (Paper V), hittade vi autoantikroppar med möjlig sjukdomsrelevans. För MS identifierades 51 målproteiner medan tre valdes ut inom narkolepsi.

De resultat som presenteras i denna avhandling utgör grunden för fortsatt analys i jakten på de proteiner som kanske kan komma att förklara uppkomsten av neurologiska sjukdomar. 
This thesis will be defended on February 62015 at 09.00, in Rockefeller lecture hall (Nobels väg 11, Karolinska Institute, Solna Campus) for the degree of "Teknologie doktor" (Doctor of Philosophy, PhD) in Biotechnology.

\section{Respondent:}

Anna Häggmark, MSc in Biotechnology

Division of Proteomics and Nanobiotechnology, School of Biotechnology

Science for Life Laboratory, KTH, Royal Institute of Technology, Stockholm, Sweden

\section{Faculty opponent:}

Prof. Katrin Marcus

Department of Functional Proteomics, Medical Proteome Center

Ruhr University Bochum, Bochum, Germany

\section{Evaluation committee:}

Prof. Lou Brundin

Department of Clinical Neuroscience, Department of Neurosurgery and Neurology

Karolinska University Hospital, Karolinska Institutet, Stockholm, Sweden

Assoc. Prof. Margareta Ramström

Department of Chemistry, Analytical Chemistry, BMC

Science for Life Laboratory, Uppsala University, Uppsala, Sweden

Dr. Joel Jakobsson

Department of Psychiatry and Neurochemistry, Institute of Neuroscience and Physiology

Sahlgrenska Academy, University of Gothenburg, Gothenburg and Mölndal, Sweden

\section{Chairman:}

Prof. Mathias Uhlén

Division of Proteomics and Nanobiotechnology, School of Biotechnology

Science for Life Laboratory, KTH, Royal Institute of Technology, Stockholm, Sweden

\section{Main supervisor:}

Prof. Peter Nilsson

Division of Proteomics and Nanobiotechnology, School of Biotechnology

Science for Life Laboratory, KTH, Royal Institute of Technology, Stockholm, Sweden

\section{Co-supervisors:}

Assoc. Prof. Jochen M Schwenk

Division of Proteomics and Nanobiotechnology, School of Biotechnology

Science for Life Laboratory, KTH, Royal Institute of Technology, Stockholm, Sweden 


\section{List of publications}

The presented thesis is based on the following five articles, referred to by their Roman numerals $(\mathrm{I}-\mathrm{V})$. All articles are included in the Appendix.

Paper I Häggmark A., Byström S., Ayoglu B., Qundos U., Uhlén M., Khademi M., Olsson T., Schwenk J. M., and Nilsson P.

Antibody-based profiling of cerebrospinal fluid within multiple sclerosis. Proteomics (2013) 13(15) pp. 2256-2267

Paper II Byström S., Ayoglu B., Häggmark A., Mitsios N., Hong M-G, Drobin K., Forsström B., Fredolini C., Khademi M., Amor S., Uhlén M., Olsson T., Mulder J., Nilsson P. and Schwenk J. M.

Affinity proteomic profiling of plasma, cerebrospinal fluid, and brain tissue within multiple sclerosis. J. Proteome Res. (2014) 13(11) pp. 4607-19

Paper III Häggmark A.*, Mikus M.*, Mohsenchian A., Hong M-G., Forsström B., Gajewska B., Baranczyk-Kuzma A., Uhlén M., Schwenk J. M., Kuzma-Kozakiewicz M. and Nilsson P.

Plasma profiling reveals three proteins associated to amyotrophic lateral sclerosis. Annals of Clinical and Translational Neurology (2014) 1(8) pp. 544553

Paper IV Ayoglu B., Häggmark A., Khademi M., Olsson T., Uhlén M., Schwenk J. M., and Nilsson P.

Autoantibody profiling in multiple sclerosis using arrays of human protein fragments. Mol. Cell. Proteomics (2013) 12(9) pp. 2657-2672

Paper V Häggmark A., Zandian A., Forsström B., Khademi M., Arnheim Dahlström L., Hallböök T., Uhlén M., Partinen M., Schwenk J. M., Olsson T. and Nilsson P.

Autoantibody targets in vaccine-associated narcolepsy. Manuscript

*Both authors contributed equally to the work. 


\section{Respondent's contributions to the included articles}

\section{Paper I}

Majority of experimental planning, performance of CSF laboratory work and data analysis. Main contributor during manuscript writing.

\section{Paper II}

Performance of CSF laboratory work and data analysis. Co-responsible author during manuscript writing.

\section{Paper III}

Main responsibility for experimental performance, data analysis and manuscript writing.

\section{Paper IV}

Development of protocol for CSF autoimmunity profiling, CSF data analysis and manuscript writing as co-responsible author.

\section{Paper V}

Majority of experimental planning, parts of the laboratory work and majority of data analysis. Main contributor during manuscript writing. 


\section{Related work not included in the thesis}

Ayoglu B., Häggmark A., Neiman M., Igel U., Uhlén M., Schwenk J.M. and Nilsson P. Systematic antibody and antigen-based proteomic profiling with microarrays. Expert Rev Mol Diagn (2011) vol. 11 (2) pp. 219-234

Häggmark A.*, Neiman M.*, Drobin K., Zwahlén M., Uhlén M., Nilsson P. and Schwenk J. M.

Classification of protein profiles from antibody microarrays using heat and detergent treatment. New Biotechnol (2012) vol. 29 (5) pp. 564-570

El Magraoui F., Eisenacher M., Schrötter A., Kuhlmann K., Heinsen H., Andrén P., Nilsson P., Häggmark A., Schmitz G., Verhaert P., Borchers C., Yoo J.S., Lee B.H., Meyer H.E., Grinberg L.T.

Developing new methods to answer old and new questions in neurodegenerative diseases: 21(st) Workshop of the HUPO Brain Proteome Project (HBPP). Proteomics. 2014 Jun;14(11) pp. $1308-1310$

Sjöstedt E., Fagerberg L., Hallström B. M., Häggmark A., Mitsios N., Nilsson P., Pontén F., Hökfelt T., Uhlén M., and Mulder J.

The Genetic landscape of the brain: transcriptomics and immunohistochemistry analysis of the human cerebral cortex and 26 peripheral tissue types. Submitted

Häggmark A., Hamsten C., Wiklundh E., Lindskog C., Mattsson C., Andersson E., Lundberg I., Grönlund H., Schwenk J. M., Eklund A., Grunewald J. and Nilsson P.

Proteomic profiling reveals four autoimmune targets in sarcoidosis. American Journal of Respiratory and Critical Care Medicine, In press

Häggmark A., Hamsten C., Wiklundh E., Lindskog C., Grönlund H., Schwenk J. M., Eklund A., Grunewald J. and Nilsson P.

Elevated levels of FN1 and CCL2 in bronchoalveolar lavage of sarcoidosis patients.

Manuscript

Emami, P., Häggmark A., Lönnberg M., Mikus, M., Kilander L., Lannfelt L., Bergqvist J., Ingelsson M., Nilsson P., Kultima K. and Shevchenko A.

Cerebrospinal fluid proteome of patients diagnosed with Alzheimer's disease - focus on data analysis and novel protein markers for improved diagnostics Manuscript 


\section{Preface}

I entered the world of research more than five years ago when I started working on my master's degree project. That project as well as many of those that followed were related to technology development in relation to neuroscience but I have also had the opportunity to work with other fluids and disease areas. The brain is to me one of our most fascinating organs and when it was time to put together a thesis structure, I decided to focus on my work within neurological diseases. I truly enjoyed learning what we currently know about the proteins that make up our brain and how they can been studied to understand involvement in disease.

There is an overwhelming amount of studies published on disease associated proteins. So instead of taking on the almost impossible task to cover everything, I decided to make use of the unique opportunity I had: to write this book my way. And so, I decided to focus on what I find most interesting; research that extends the limits of what we already know and how the findings we make can add a small piece into the big puzzle of biology.

Everyone who has, or is about to get, a $\mathrm{PhD}$ knows that it is a long process that has its ups and downs. In my work, while aiming to discover disease related profiles, I have struggled to understand sample composition, systematic bias, effects of data normalisation, the nature of antibody interactions and individual variation. Therefore, I have dedicated a chapter of this book to the challenges we face in search for proteins associated to disease. There have been times when I have felt like these challenges are preventing true biological discoveries, however, I have come to believe that approaching a problem from different angles is the key that will take us closer to the solution. It is really like they say; one person can't do it alone but we can all do it together. I hope you will enjoy reading my book.

Anna Häggmark

December 2014 


\section{Contents}

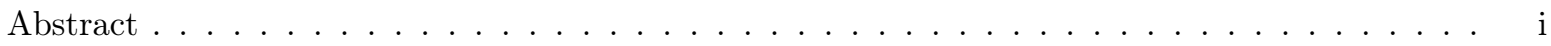

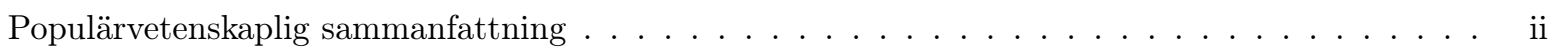

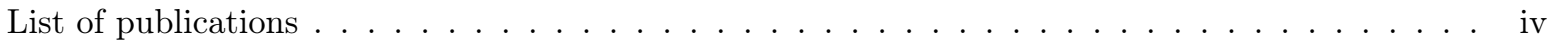

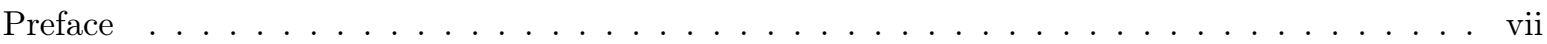

Brain, cerebrospinal fluid and blood: How to access the neuroproteome $\quad 1$

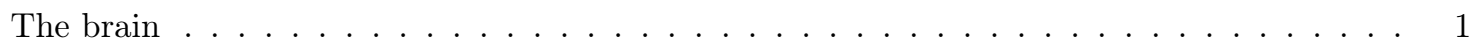

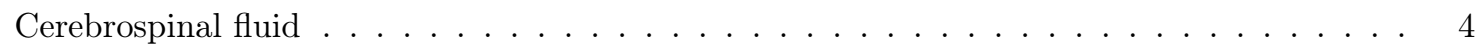

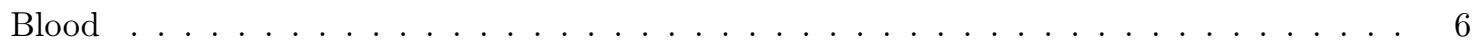

\begin{tabular}{l|l} 
Neuroproteomic profiling & $\mathbf{8}$
\end{tabular}

Defining the neuroproteome $\ldots \ldots \ldots \ldots \ldots \ldots$

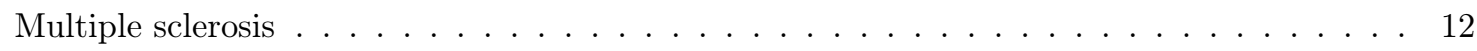

Amyotrophic lateral sclerosis $\ldots \ldots \ldots \ldots \ldots \ldots \ldots \ldots \ldots$

Narcolepsy . . . . . . . . . . . . . . . . . . . . . . . . . . . 19

Alzheimer's disease . . . . . . . . . . . . . . . . . . . . . . . 21

Parkinson's disease . . . . . . . . . . . . . . . . . . . . . . 23

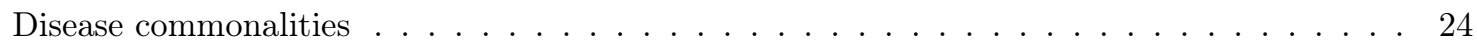

Analytical challenges: From sample handling to individual variation $\quad 27$

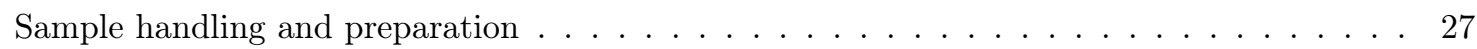

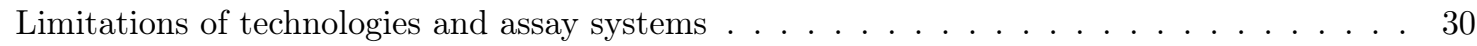

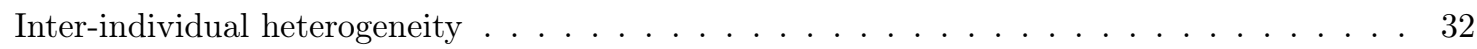

$\begin{array}{ll}\text { Present investigations } & 35\end{array}$

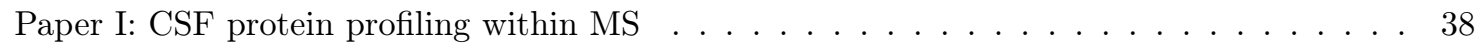

Paper II: Antibody-based analysis of plasma, CSF and brain tissue in MS . . . . . . . . . 41

Paper III: Disease associated protein profiles in ALS . . . . . . . . . . . . . . . . . . 43

Paper IV: Profiling the autoimmunity repertoire of MS patients . . . . . . . . . . . . . 45

Paper V: Autoimmunity profiling of serum within narcolepsy . . . . . . . . . . . 47

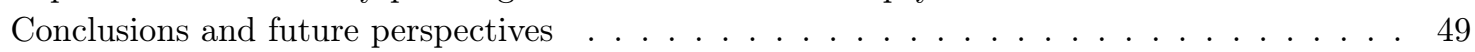

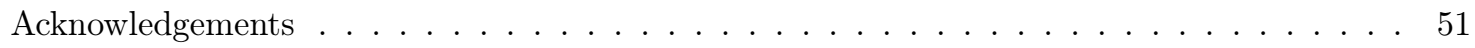

$\begin{array}{ll}\text { Bibliography } & 54\end{array}$ 


\section{Brain, cerebrospinal fluid and blood: How to access the neuroproteome}

In 1837, the first observation of a single nerve cell was described by Johannes Evangelist Purkinje [1]. This was an important finding at a time when there was a vivid debate regarding the organisation of the nervous system. One group of scientists claimed that nerve cells were fused together to form a tissue that could transfer nerve signals. Others instead argued that the nerve system consisted of single cells that were physically connected to each other [2]. Today, we know that the brain is composed of billions of neurons, axons and synapses, making it one of the most complex structures currently known [3]. It is the organ that processes information and together with the spinal cord, it controls and coordinates our body. Neuronal function, signal transmission and cell to cell communication are processes mediated by proteins and alterations in protein levels can result in a dysfunctional physiological state.

This thesis introduction aims to describe our current understanding of the neuroproteome and its involvement in some of our most common neurological disorders. It also summarises the technologies frequently used to study proteins and the challenges related to discovery of disease associated protein profiles.

\section{The brain}

The brain has for centuries been the focus of anatomical and medical research aiming to understand neurological processes and diseases. Tissues derived from postmortem brains have yielded descriptions of main structures and regions with specific histological characteristics. These have during later years been complemented with mechanistic insights of neuronal activity through emerging technologies [4]. The brain is composed of three major structures; the two cerebral hemispheres including cerebral cortex, the cerebellum and the brain stem (Figure 1). These structures can be further subdivided into numerous 
components and regions, including the frontal, parietal, temporal and occipital lobes, each of which hold different functions. Several other specific regions have been associated to disease, such as hippocampus in Alzheimer's disease (AD) or substantia nigra in Parkinson's disease $(\mathrm{PD})$.

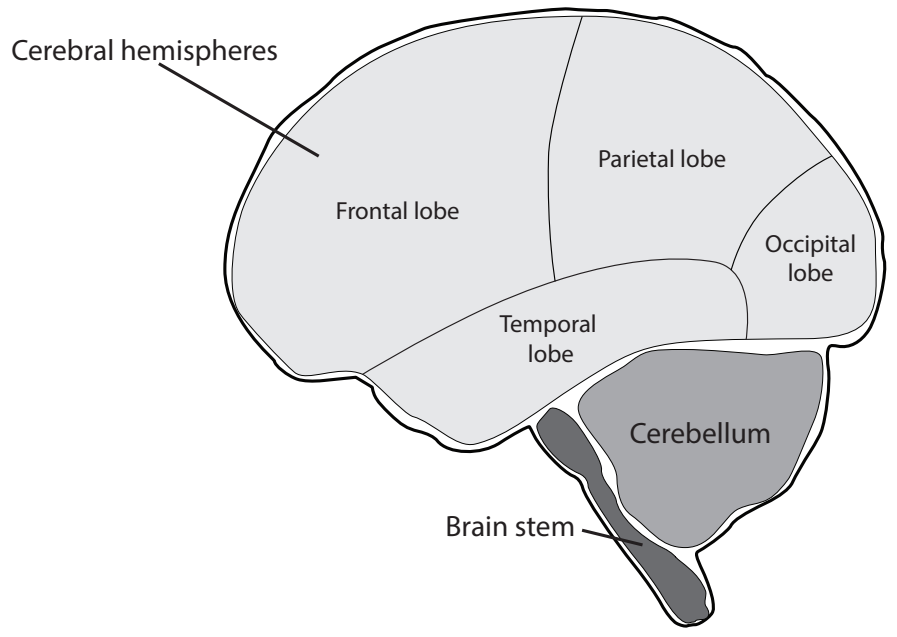

Figure 1: The human brain is composed of three main structures; the cerebral hemisphere including cerebral cortex, the cerebellum and the brain stem. The cerebral hemisphere can be further subdivided into the frontal, temporal, parietal and occipital lobes.

The cell population of the brain is commonly categorised into neurons and glial cells. Neurons, or nerve cells, are cells that transfer nerve signals throughout the body. A typical neuron has a cell body with an axon and dendrite extensions responsible for transmission of the electrical impulse. The axon ends in one or several axon terminals where neurotransmitters are released into the synapse, see Figure 2. These molecules then bind to dendrites of the receiving cell, an interaction that induce alterations in membrane potential. When the membrane potential reaches a certain threshold the cell depolarises along the axon, in a process referred to as action potential, causing a new release of neurotransmitters into the next synaptic space. Many neurons, both in the central nervous system (CNS) and in the periphery have myelinated axons. These axons are covered by sections of myelin sheaths that insulate the nerve and thereby enable faster signal transmission. Myelin is mainly composed of lipids but also contains proteins such as myelin oligodendrocyte glycoprotein (MOG), myelin basic protein (MBP) and proteolipid protein (PLP). The electric signal in myelinated neurons distinctly jumps between non-myelinated areas known as the nodes of Ranvier in a process referred to as saltatory conduction.

The other major cell type, glial cells, can be further subdivided into microglia, oligoden- 


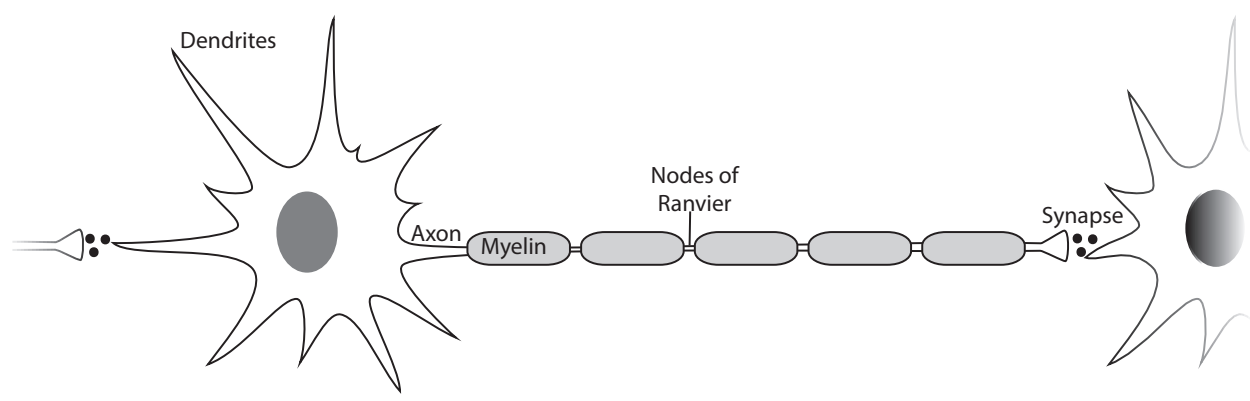

Figure 2: Schematic representation of a neuron. Neurotransmitters released into the synapse bind to dendrites on the receiving neuron, thereby inducing an action potential along the axon.

drocytes and astrocytes. Microglia are equivalent to macrophages in the periphery and are important components of the CNS immune system [5]. Upon interaction with pathogens or damaged tissue, these cells enter an activated state acquiring phagocytic properties while secreting inflammatory proteins. Oligodendrocytes on the other hand are cells mainly responsible for myelin formation while astrocytes exhibit a number of various functions. These include maintenance of the blood brain barrier (BBB) and regulation of neuronal activity through synthesis or absorbance of neurotransmitters at the synaptic site. In addition to changes in molecular expression, astrocyte activation due to external stimuli can initiate morphological changes and induce scar formation to limit CNS damage caused by an inflammatory response [6].

The above-mentioned cell types are the main constituents of brain and proteins present in this tissue is commonly studied through post mortem materials. Studies investigating the stability of nucleic acids and proteins in post mortem brains indicate that these molecules are relatively stable [7]. There are currently several protocols applied to preserve the stability and structure of collected tissues. Two of the most commonly used include freezing or formalin fixation followed by paraffin embedding [8]. Systematic collection of tissues are for example performed within brain bank initiatives, where both formalin fixed and frozen postmortem brains are available together with clinical information [9]. These tissue collections are invaluable resources for neurological research but declining autopsy rates and the variation in ethical and legal regulations among countries restrict their use.

Brain tissue has traditionally been analysed as either whole sections or homogenates. Lately however, methods to more specifically isolate certain cell types, single cells or even cellular components have emerged [10]. It is now possible, through technologies like laser microdissection, to in detail study only certain brain areas or single cells. In addition, protocols for isolation of cellular components are available and have for example enabled 
analysis of the synaptic environment [11]. This approach is especially interesting in the context of diseases where not only certain regions but also cell types are affected. This includes examples such as hypocretin producing neurons in narcolepsy or dopaminergic neurons in PD.

\section{Cerebrospinal fluid}

The first observation of an intracranial fluid was described by the Egyptian Imhotep already in 3000 B.C [12]. Although this observation was documented and made public at the time, it was later forgotten and his documents not re-discovered until the 19th century. Meanwhile, 400 B.C. Hippocrates made a similar observation of water surrounding the brain and Claudius Galen a few hundred years after described an "excremental liquid" that he believed to be secreted through the nose [13]. The first to observe ventrical liquid was Nicholo Massa and he published his findings in 1536. Massa's work together with Emanuel Swedenborg's later finding that fluid was dispensed in ventricles and spinal cord was of great interest to the Swiss physiologist Albrecht von Haller. He, in 1747, presented the theory of liquid secretion into ventricles and subsequent reabsorption in the base of the skull and spine [12]. During that time, the general autopsy process was modified to not include separation of the head from the body, an adjustment important for studies of intracranial fluid. Domenico Felice Cotugno continued to extensively study formation and absorption of this liquid and in 1842, Francois Magendie introduced the term cerebrospinal fluid (CSF).

In 1664, Thomas Willis made what is believed to be the first observation of disease related changes in CSF during examination of patients with meningitis. More than 200 years later, Walter Essex Wynter treated tuberculous meningitis through a spinal tap and during the same year, lumbar puncture was suggested as a method for diagnosis and treatment of diseases [13].

Due to the scarce availability of tissue material, CSF is commonly used to study normal and pathological states of the human brain. Despite the lack of spatial resolution that is obtained through analysis of tissue, compounds present in CSF can give insight into the physiological conditions of this well protected organ. In addition, CSF can be used for diagnosis of several neurological disorders [14] [15]. This fluid has several functions, including to decrease the apparent brain weight, to absorb physical force and to transport nutrients and waste products in and out of the CNS. It is still, as described already in the 1890s, collected through the relatively invasive method of lumbar puncture.

As suggested by von Haller and Cotugno, the majority of CSF is formed in the choroid plexus of the ventricles. This is a structure consisting of a monolayer of epithelial cells 
connected by tight junctions commonly referred to as the blood-CSF barrier (Figure 3) [16]. These epithelial cells secrete sodium into the ventricles, resulting in an osmotic pressure and water transfer from the blood into the ventricular space. In adults, approximately 500 $\mathrm{ml}$ of water diffuse through the blood-CSF barrier per day and, since the total CSF volume is $150 \mathrm{ml}$, the fluid is exchanged several times daily. The production rate has been shown to vary, with maximum production during night and lower during day [17]. From the choroid plexus, CSF flows from the first or second ventricle, through the third and into the fourth, after which it divides into the cortical and lumbar subarachnoid space [18].

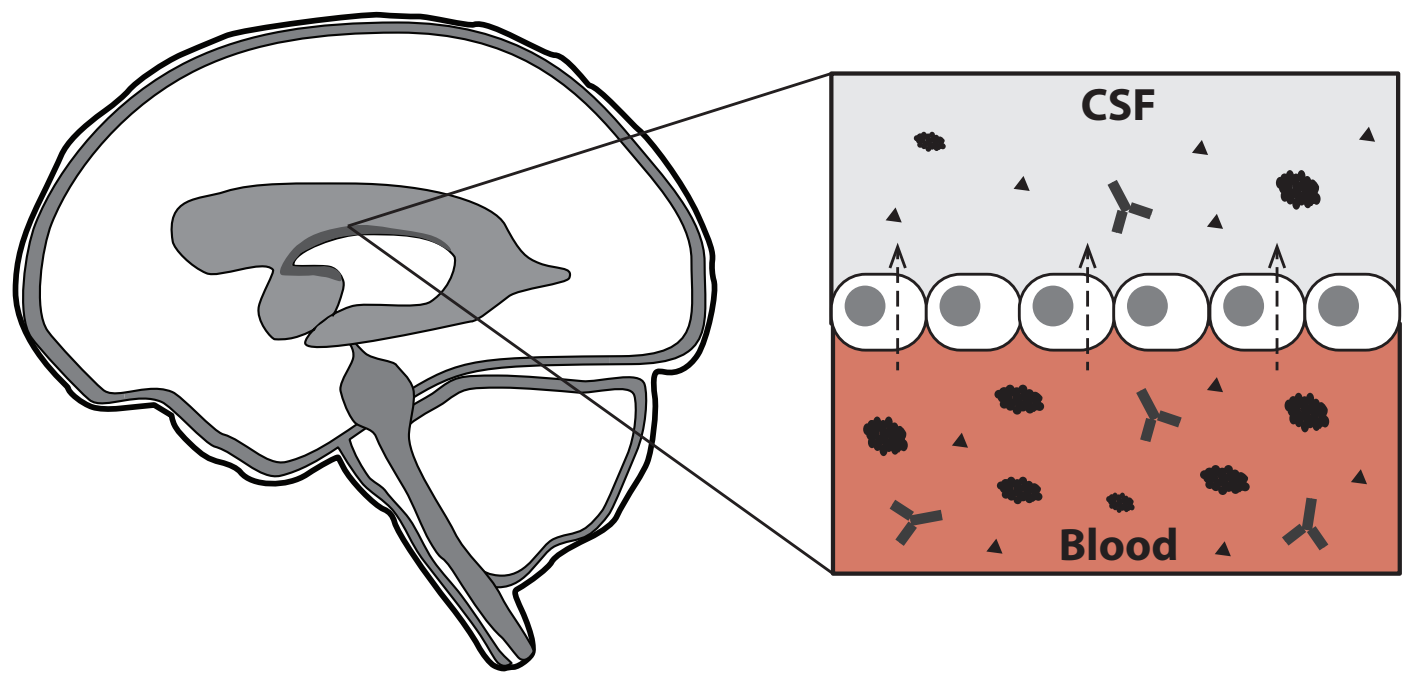

Figure 3: CSF is mainly formed in the lateral ventricles by filtration of blood through the blood-CSF barrier.

Under normal physiological conditions, diffusion of proteins over the blood-CSF barrier is restricted and its integrity is of great importance for protection of the CNS. Out of the total volume, $99 \%$ of CSF is composed of water with the remaining percent shared by proteins and other molecules such as nutrients and salts [18]. CSF protein content is to $80 \%$ represented by proteins originating from blood and only $20 \%$ of proteins are derived from CNS [19]. The fluid has under normal conditions a total protein concentration of approximately $0.5 \mathrm{mg} / \mathrm{ml}$, more than 100 times lower than the concentration in plasma or serum. Its protein composition is also less complex even though, similarly to blood, half of the protein amount is composed of albumin and immunoglobulins [15]. Huhmer et alsummarised established reference intervals for 49 known CSF proteins, showing that concentrations span at least nine orders of magnitude [20].

The exact mechanism of how CSF is drained into the systemic circulation in humans has not yet been fully understood. However, two main routes have been suggested, namely 
the arachnoid granulations in the subarachnoid space of the cortical and spinal area as well as drainage via the olfactory nerve into the lymphatic system. Through the outflow of this proximal fluid into blood, it is possible to detect CNS components in serum or plasma [21] [18].

\section{Blood}

In contrast to CSF, blood is a systemic fluid that acts as the main transportation system of the whole body. Approximately half of the total blood volume is comprised of cells, including erythrocytes (red blood cells), leukocytes (white blood cells) and thrombocytes (platelets). The other half is represented by blood plasma, a liquid component mainly containing water, but also soluble compounds such as proteins, carbohydrates, salts and gases [16] [22]. The blood transports oxygen to and carbon dioxide from all cells in the body and also facilitates transport of signalling molecules, nutrients and waste products. The majority of plasma proteins are produced in the liver including albumin, the protein constituting more than half of the total protein amount. A recent study by Kampf et al more deeply investigated the human liver transcriptome and reported expression of more than 12000 genes [23]. Among the most abundant transcripts were typical plasma proteins like apolipoproteins, transferrin and fibrinogens. This study also showed that a third of the expressed genes contained a signal peptide, indicating that approximately 4000 proteins can potentially be secreted from this organ into blood. In addition to proteins secreted by the liver, blood also contains molecules produced in other tissues and organs. As stated by Leigh Anderson, most proteins are likely to appear in the systemic circulation at a certain time point as a result of active secretion or tissue leakage [24].

Several efforts have aimed to establish the complete human plasma proteome and one of the first was published by Anderson et al in 2004 [24]. In this study, plasma samples were analysed in four parallel labs through several mass spectrometry-based approaches. A list of 1175 proteins were reported, however, only 195 were detected with more than one method and as few as 46 found using all approaches. Similarly, the Human Plasma Proteome Project initiated analysis of one sample in 35 laboratories and assembled a list of more than 3000 detected proteins [25]. This list was later reduced to 889 proteins and the challenges of protein identification using mass spectrometry discussed, bringing up high abundant peptides as one of the main reasons for low protein coverage [26]. Recently, Farrah et al performed meta analysis of several public data sets and reported 3553 proteins to have been identified in human plasma [27]. The proteins present in blood, either through active secretion or tissue leakage, have been found to be present at concentrations spanning eleven to twelve orders of magnitude [24]. In contrast to this wide range, the ten most abundant proteins comprise about $90 \%$ of the total protein amount, greatly contributing 
to the complexity of this body fluid.

The reabsorption of CSF into circulation, as mentioned previously, provides an explanation to how brain-derived proteins can be found in blood. The complex composition of blood, including the presence of a few highly abundant proteins, pose a challenge in detecting these and other low abundant molecules. Nevertheless, structural components of neurons and other brain-derived proteins have been successfully detected in plasma of patients with neurological disorders [28] [29]. This demonstrates that using the right tools, blood can be a valuable source of information also in CNS focused research. Due to the minimally invasive procedures and routinely collection of this sample material, blood-based assays represent ideal tools for diagnosis and monitoring of disease progress. 


\section{Neuroproteomic profiling}

All proteins present in the nervous system can collectively be referred to as the neuroproteome. Currently, affinity-based technologies and mass spectrometry methods are the two main approaches used to analyse proteins. Affinity proteomic methods are dependent on reagents in the form of antibodies or other binder molecules such as antibody fragments, Affibodies or aptamers. These reagents are commonly used for protein profiling through microarray technologies where multiple analytes can be measured in parallel using only a few microliters of sample. Also, flexibility in the array setup allows for both single binder assays utilising direct sample labelling [30] as well as assays based on multiple binding events, such as conventional ELISAs or proximity ligation assays [31]. In mass spectrometry on the other hand, proteins are analysed through the mass to charge-ratio of ionised proteins or peptides. This technology allows for profiling assays both through broad peptide detection in shotgun approaches as well as targeted protein analysis by selected reaction monitoring (SRM) assays.

\section{Defining the neuroproteome}

Both affinity proteomics and mass spectrometry methods have been used to analyse proteins of the nervous system. The neuroproteome can provide insight into what it is that makes the brain different on protein level from other organs and tissues of the human body. Such information can also be obtained by analysis of gene expression, as performed in the field of transcriptomics. Even though the transcriptome might not be directly corresponding to the proteome, knowledge of the genes expressed provides information on what proteins that could be present in a given sample. Many efforts aiming to study proteins within neuroscience are, due to the limited availability of tissue and CSF from healthy individuals, based on samples from diseased patients. However, the following section is focused on information obtained from individuals without known disease involvement. 


\section{Transcriptomics}

In transcriptomics, mRNA molecules are sequenced as a measure of gene expression. One of the major initiatives aiming to create a map of the human brain transcriptome is the Allen Human Brain Atlas based on histological and transcriptomic analysis [32]. The data available in this atlas indicates that there is a variation in gene expression based on the cell populations present in different brain regions. Another study, including 27 different tissues, performed transcriptomic analysis to map human gene expression in the search for housekeeping and tissue enriched genes [33]. Fagerberg et al reported that 46 $\%$ of the genes were expressed in all tissues analysed and only $12 \%$ appeared as tissue enriched. A similar observation was made in a separate study, as reported by Ramsköld et al [34]. They also concluded that genes commonly expressed in all tissues were mainly represented by intracellular proteins involved in metabolism, transcription and translation. In both these studies, brain was found to be among the tissues with the largest number of expressed genes.Furthermore, it also displayed one of the most complex transcriptomes and largest number of tissue enriched genes. According to Fagerberg and colleagues, 13992 genes were expressed in the cerebral cortex. Further analysis of these revealed 571 were brain enriched, representing 13\% of the total mRNA amount (Figure 4) [Sjöstedt et al, submitted]. These 571 genes were overrepresented by membrane and extracellular proteins involved in synaptic transmission, and in addition, localisation analysis on protein level revealed staining of both neurons and glial cells.

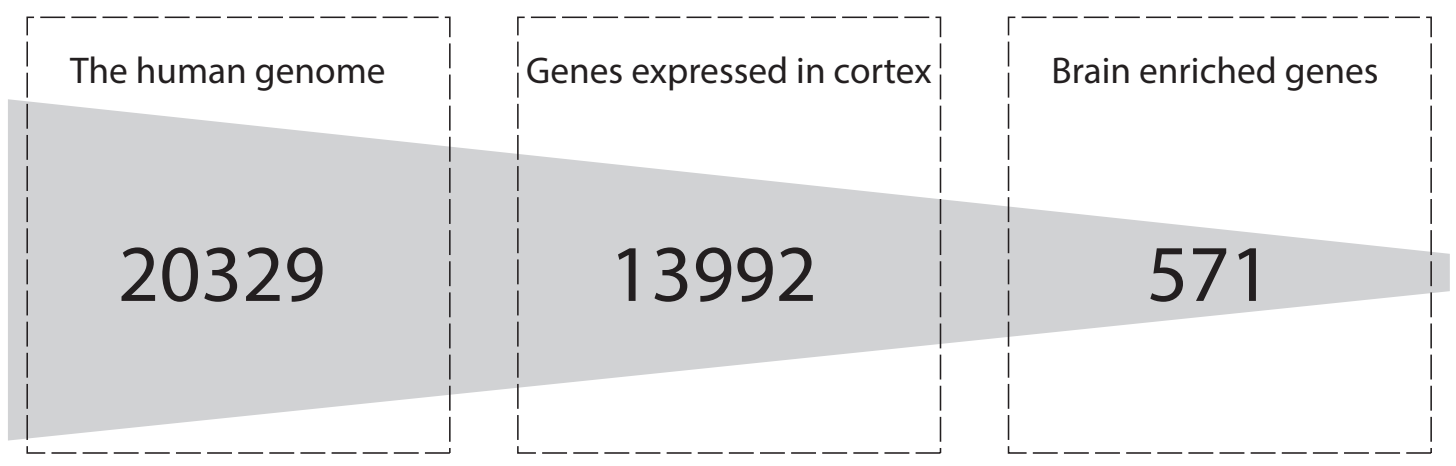

Figure 4: The brain transcriptome as reported by Fagerberg et al [33]. Out of all 20329 human protein encoding genes (Ensembl v. 69), 13992 were expressed in frontal cortex. Of these, 571 were found to be enriched in brain compared to the other tissues analysed.

Several studies have investigated the correlation between transcriptomes and proteomes [35]. In contrast to what perhaps could be assumed based on the central dogma, many 
of these studies indicate that the transcriptome alone does not predict the proteome. As discussed by Haider et al, protein stability and half-life in combination with differential translational efficiency might contribute to the differences observed. Also, limited sensitivity and bias in protein detection of the methods used for proteomics is a possible source of error. On the other hand, Lundberg and colleagues reported a positive correlation in their analysis using RNA and protein ratios in different cell lines [36]. To take the tran-

scriptome one step closer to the proteome, there are emerging methods for profiling of the translatome. Here, only mRNA molecules attached to ribosomal complexes are sequenced and thus, only translated transcripts are detected. This approach has been used for profiling of rodent brains [37] [38] but so far, studies on human brain tissues are lacking. It still remains to be seen if this approach will offer a better representation of the proteome. Meanwhile, parallel efforts are ongoing to map the proteins of human brain.

\section{Proteomics}

Proteomic studies can be performed using whole tissue samples, isolated cells and body fluids. There have been numerous studies aiming to discover disease related patterns through proteomic profiling including healthy or disease controls, but systematic efforts to establish the healthy proteome are still few. Although this thesis is focused on protein detection in human body fluids, many proteins related to disease pathogenesis are most likely originating from the affected tissue. Two recent publications describe how highresolution mass spectrometry have created a draft map of the human proteome and both studies included brain as one of several analysed tissues [39] [40]. In these studies, as well as several others addressing the brain proteome, the brain was represented by frontal cortex. It is likely that many proteins expressed by neurons and glial cells in different brain regions are similar, although different functions and distinct involvement in disease suggest that regional differences are also to be found. To address this, several studies have aimed to establish region-specific brain proteomes through various shotgun mass spectrometry approaches [41] [42] [43] [44] [45] [46]. While identifying between 300 and 2500 proteins, the overlap between different regions are low. However, as discussed by the authors, this observation is perhaps reflecting differences in sample preparation procedures in addition to true biological variation [46] [47] [48]. As for any sample type, membrane proteins pose a challenge in terms of detection but through adapted sample processing procedures such proteins have also been successfully analysed [49] [50].

Taking these results together, a great variety of proteins have been identified as components of the human nervous system. As also indicated by transcriptomic studies, the proteins observed in different regions are believed to reflect the presence of specific cell types. Through the development of laser microdissection technologies it has become possi- 
ble to also isolate single cells for further analysis. However, the branching of neurons and close interactions with other cells types together with incompatibility of standard sample preparation procedures have so far limited the use within proteomics [51]. Nevertheless, it has enabled the isolation of both neuronal and glial cells for cultivation and subsequent analysis of their proteomes [52] [5].

Regardless if tissue analysis is performed through homogenates or more sophisticated dissection techniques, the access of material within the field of neuroscience is limited. Instead of tissue, CSF is commonly used to get an insight into the human brain proteome. The total protein concentration of this fluid varies among individuals but usually ranges between 100 and $500 \mu \mathrm{g} / \mathrm{ml}$ in healthy adults [20]. In terms of protein composition, CSF is similar to blood with more than half of the protein amount composed of albumin. Other high abundant proteins include IgG, prostaglandin D2 synthase, transthyretin, transferrin, cystatin $\mathrm{C}, \alpha-1$-antitrypsin and $\alpha$-2-macroglobulin. The majority of these proteins are not locally produced, but originate from blood [53]. Several studies have been performed to establish the CSF proteome through the use of 2D gels coupled to mass spectrometry. Even though methods were optimised regarding spot detection and protein identification, more than 100 proteins were seldomly detected using this approach. In addition, the results were largely affected by high abundant proteins [20]. The introduction of liquid chromatography and additional fractionation methods have increased the possibilities to detect a larger number of proteins. In 2005, Zhang et al published a list of over 300 proteins from undepleted but fractionated CSF and concluded that the two largest groups were proteins related to inflammation and protein synthesis or degradation [54]. A few years later, Pan and colleagues complied a list of 2594 unique proteins identified based on three datasets using different separation methods and mass spectrometry platforms [55]. They reported that the majority of proteins were either related to CNS structure and function or of probable plasma origin. Another study by Zougman et al identified 798 proteins that were overrepresented by involvement in neuronal processes and immune response [56]. In 2010, almost all of the 798 together with approximately 2000 additional proteins were identified in one single experiment as reported by Schutzer and colleagues [57]. In this study, the inter-individual variation in terms of protein levels was compared to longitudinal samples taken from the same person at least four weeks apart. This analysis revealed the longitudinal variation to be much lower compared to the variance between individuals. Also, a recent study by Guldbrandsen et al identified over 3000 CSF proteins using several sample preparation approaches and the researchers made these results publicly available through the CSF Proteome Resource [58].

The protein composition of CSF has been reported to vary if collected from ventricles or, as most commonly made, by lumbar puncture [59]. A decreasing gradient in brain-derived proteins towards the spine has been described while proteins originating from meninges 
and blood have been found to increase in the same direction. However, as pointed out by Bradner et al, this study was based on ventricular samples from different subjects than lumbar CSF, introducing bias and unreliability to such extent that no conclusions should be drawn. Bradner and colleagues instead measured the levels of four proteins derived from the brain, meninges and blood in paired ventricular and lumbar CSF samples and could not observe a concentration gradient for brain proteins [60]. On the other hand, meningeal and blood proteins were again found as increased in lumbar CSF. A recently published paper reports a more systematic analysis of CSF dynamics using mass spectrometry [53]. Again, a gradient was observed for blood derived proteins while concentrations of brain proteins were stable. The authors discuss that because brain proteins are mainly diffused into CSF in the ventricles early in the process of CSF formation, their concentration is kept constant throughout CSF circulation. On the contrary, proteins from meninges and blood probably diffuse into CSF at multiple locations in the subarachnoid space leading to accumulation and increased protein concentration [18].

Proteins are often regarded as functional mediators and many diseases, including neurological disorders, are associated to protein dysregulation. The susceptibility of developing disease is in some diseases linked to genotype, while in others no such association has been observed. Instead, environmental factors such as viral infections or the interaction of genetics and environmental exposure have been found as related to disease onset. Regardless of the underlying cause, proteins are highly likely to be involved in disease pathogenesis and are commonly the focus of disease related research. The following sections describe disease characteristics, the current understanding of protein involvement and explorative efforts within some of the most common disorders affecting the nervous system.

\section{Multiple sclerosis}

Multiple sclerosis is one of the most common neurological diseases and it is primarily characterised by both inflammatory and neurodegenerative components [61]. In these patients, myelin sheaths surrounding the axons are degraded, resulting in impaired nerve function [62] (Figure 5). For $80 \%$ of patients the disease starts with what is referred to as clinically isolated syndrome (CIS) where a brain lesion results in an acute episode of symptoms. This can also occur in other conditions than MS, however if it is followed by recurrent symptoms linked to additional brain lesions there is strong supporting evidence for diagnosis of relapsing remitting MS (RRMS) [63]. At early stages, this subtype of disease is characterised by periods of complete remission between clinical episodes. As the disease progresses, the ability to completely recover is lost. More than half of RRMS patients later develop a secondary progressive form of disease (SPMS) with gradual accumulation of disability. For approximately $20 \%$ of all MS patients, the disease instead 
starts in a progressive fashion and patients in this subgroup are diagnosed as primary progressive MS (PPMS). In these patients, where clinical episodes can not be distinguished, diagnosis require supporting evidence in the form of MRI imaging indicating spinal cord lesions or alternatively, CSF oligoclonal bands. Such bands indicate the presence of antibody producing B-cell clones in the CNS but not in blood and can be observed for 90-95 $\%$ of all patients [62] [64]. These intrathecally produced antibodies are not specific for MS although a higher number of bands are commonly detected in MS patients compared to other neurological conditions [65].

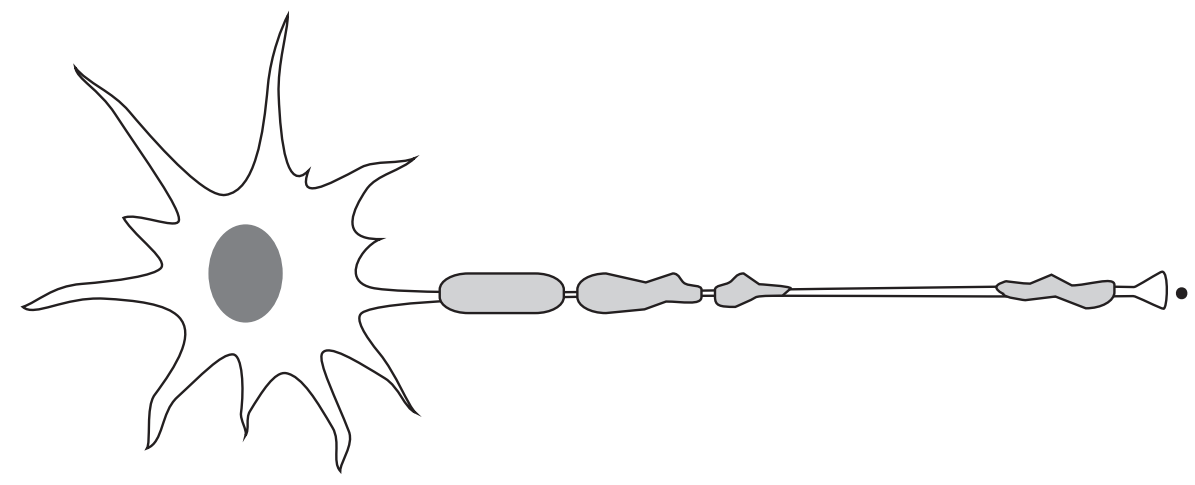

Figure 5: Multiple sclerosis is characterised by demyelination of neurons.

Already in the 1970s, association of HLA genes to the development of disease was discovered, indicating the influence of genetic components [66]. Since then, numerous genetic studies have been performed revealing MS as a genetically complex disease [67]. Several environmental factors have also been suggested to be involved, including viral infections, obesity, smoking and vitamin D levels [68]. Among viral infections, the Epstein Barr virus (EBV) is the most widely discussed. Studies indicate that titers of anti-EBV antibodies are increased before disease onset and that primary infection in adolescents appear to increase the risk [69]. In addition, episodes of relapse in RRMS patients have been associated to infections, especially with upper respiratory and gastrointestinal involvement. It has also been shown that T-cells in the lung can acquire ability to enter the CNS [70]. This finding supports the theory of infiltration of autoreactive lymphocytes as a possible mechanism for at least a subset of patients. Another study by Hedström et al revealed interaction between HLA genotype and smoking, also pointing in the direction of lung involvement in disease development [71]. 


\section{CSF protein profiles}

A comprehensive review by Farias et al summarises the proteomic efforts performed during the last decade to study protein levels related to MS [72]. Even though no proteins so far have been approved for clinical use, there are several proteins suggested as markers of disease. Within MS, the majority of protein profiling studies have been performed using mass spectrometry to compare protein levels in CSF from patients to a control group. Due to the limited availability of CSF from healthy individuals, patients with other neurological diseases (ONDs) have often been used as controls. Ottervald et al analysed 112 CSF samples from MS patients and ONDs without inflammation using 2D gels coupled to mass spectrometry [73]. Based on the results, they developed immunoassays for ten proteins and analysed an additional set of 209 samples. Protein levels were found to differ not only between MS patients and controls but also between different subtypes of disease. While Ottervald and colleagues performed depletion and analysis of normalised protein amounts, Stoop et al reported the use of undepleted CSF for protein profiling. They included both inflammatory and non-inflammatory controls (iOND and OND) in their design and could conclude that a larger number of differentiating proteins were found in comparison with the non-inflammatory controls [74]. Based on this data, no differences between MS subtypes were identified. Medium and high abundant proteins were the focus in a study reported by Krooksven et al who performed label-free shotgun mass spectrometry analysis of undepleted CSF samples [75]. Apart from IgG levels, all other proteins identified as significantly different between the 17 RRMS patients and 17 ONDs analysed were found to be lower in the MS patients. However, analysis of non-depleted samples with large differences in high abundant proteins, such as immunoglobulins, potentially results a lower chance of detecting other peptides. Despite differences in study design and methodology, several proteins including contactin 1 and vitamin D-binding protein were found as disease related in more than one of these studies.

All the above described used label-free methods for protein profiling. A study reported

by Comabella and coworkers explored the differences between CIS converters and nonconverters using an isobaric labelling strategy [76]. Subsequent verification was performed using immunoassays of two separate sample collections revealing increased levels of chitinase 3 -like 1 in CIS converters. Through the use of colour-coded beads, immunoassays can also be applied in multiplex formats for protein profiling studies. As described in Paper I, we have developed a protocol for CSF protein profiling using antibodies in combination with the bead-based technology. Through analysis of in total 339 samples from MS patients, ONDs and iONDs, two proteins were found at altered levels among MS subtypes or in MS compared to the controls. The levels of these two proteins, GAP43 and SERPINA3, were subsequently verified in additional samples, as reported in Paper II. 


\section{Protein profiles in blood}

Even though CNS proteins are likely present in blood at low levels, brain-derived proteins have successfully been detected also in this body fluid. In addition, symptoms appearing in the periphery together with increasing evidence of involvement of additional organs in disease development, suggest that peripheral factors reflecting MS pathology could be found in the systemic circulation. Even so, the number of studies analysing blood-based materials with proteomic technologies for discovery of MS related profiles are much lower than reports based on CSF analysis [77]. In Paper II, we investigated disease related profiles based on 443 plasma samples from an MS sample collection, also using the suspension bead arrays. The majority of differences were observed when comparing SPMS patients to other sample groups and the protein IRF8 was found to display the most interesting results. In this study, we also performed immunoflourescent staining of human brain tissue for proteins selected based on the CSF and plasma results. This analysis revealed neuronal, astrocyte, microglial and astrocyte staining.

\section{Autoimmune targets in MS}

In addition to efforts on protein profiling, specificities of the $\operatorname{IgG}$ repertoire present in both CSF and plasma of MS patients have been investigated through several different approaches as reviewed by Fraussen et al [78]. Antibodies to the major components of myelin have been extensively studied. Reactivity to MBP has been reported for 25-77\% of MS patients but also in ONDs and healthy controls. Another component, MOG, is in fact the antigen used for induction of the commonly used animal model Experimental Autoimmune Encephalomyelitis (EAE). This protein has revealed IgG reactivity in both MS patients as well as control populations, however in some studies with similar frequencies. Interestingly, this reactivity appears to be highly dependent on protein conformation [79]. Additional proposed autoimmune targets include proteins expressed in neurons such as neurofilaments, tubulin and neurofascin. Astrocyte and oligodendrocyte components have also been suggested, for example KIR4.1, a membrane protein in one study found to display higher reactivity in MS patients [80]. This discovery was made using a proteomics approach where purified $\operatorname{Ig} G$ from patient sera was investigated for reactivity to human brain tissue lysate. While 2D-DIGE and subsequent MALDI analysis revealed the protein identity, assays using protein fragments could map the reactivity to the N-terminal extracellular loop. The initial results were verified in independent sample materials, however several attempts to replicate this finding by other labs have failed to reveal differential reactivity [81]. Current evaluation is pointing in the direction of glycosylation patterns as the cause

of discordant results. Another astrocyte protein, namely SPAG16 was identified as one of 
eight autoreactive targets by Somers et al using another approach [82]. They constructed a cDNA library based on MS lesions and enabled multiplexed analysis of antibody reactivity through a phage display system.

Antigen microarrays have also been utilised for the purpose of antibody screenings as initially described by Kanter et al [83]. Their array contained 50 lipids from CNS that enabled identification of a set of analytes differentiating MS patients from ONDs. Quintana and colleagues later created a microarray with 362 myelin and inflammatory antigens and could similarly distinguish patients from healthy controls using both IgG and IgM profiles [84]. A different study design was used by Beyer et al who analysed CSF reactivity to over 300 proteins or fragments representing kinases, cell signalling and metabolic proteins [85]. The patients, 15 individuals diagnosed with RRMS, were compared to 15 subjects with suspected CNS infection revealing differential reactivity towards 100 antigens. Two of these, heat shock protein 70 and amyloid beta, was also reported as reactive by Quintana et al. Analysis using a set of antigens not selected based on previous disease knowledge represent a more unbiased approach, with potential of discovering novel autoantigens. As we report in Paper IV, IgG reactivity in serum of $90 \mathrm{MS}$ patients and ONDs was analysed towards 11520 human protein fragments using planar antigen arrays. Verification was performed for a selected set of antigens in an extended sample material including 376 patients and controls. Differential reactivity was observed for 51 antigens which currently are under further evaluation in approximately 2200 MS patients and population-based controls [Ayoglu et al, unpublished]. The results so far indicate anoctamin 2 as a potentially novel autoimmune target for MS.

Interestingly, autoreactive antibodies related to MS have been found to be cross-reactive to infectious antigens. Antibody fragments generated from blood lymphocytes of MS patients revealed not only reactivity to MBP, but also recognition of LMP1, an EBV membrane protein [86]. Hughes et al discovered cross-reactivity of bacterial antigens to both MBP and MOG [87] and furthermore, T-cells in mice recognising MOG have been shown to be polyspecific and also bind a fragment of neurofilament medium due to linear sequence homology [88]. These findings implicate the potential of molecular mimicry as an underlying cause of disease.

\section{Amyotrophic lateral sclerosis}

Amyotrophic lateral sclerosis (ALS) is regarded as the most common motor neuron disease worldwide [89]. It is characterised by loss of both upper and lower motor neurons (UMN and LMN) leading to muscle weakness and atrophy (Figure 6). More than $80 \%$ of patients are affected by a sporadic form of disease (SALS) with yet unknown cause. 
The remaining are classified as familial ALS (FALS) based on family history of disease. Genetic mutations have been identified for $75 \%$ of FALS patients and these discoveries have greatly contributed to the current understanding of disease pathogenesis. The first genetic mutation to be discovered, SOD1, is present in approximately $20 \%$ of FALS cases while alterations in the more recently found C9orf72 is observed in $40 \%$ of familial patients. Another gene, RNA binding protein FUS (FUS), has been associated to early onset ALS and additionally, mutations in TAR DNA-binding protein (TARDBP) were found in $5 \%$ of the FALS population. These four genes are the major genetic factors identified so far and although mainly related to FALS, they have also been found in a few percent of SALS patients. Three of them are related to RNA metabolism, and so are also additional genes identified with mutations in smaller subsets of patients [90]. Genes related to protein degradation and autophagocytosis have also been associated to disease development. Intracellular protein aggregates composed of ubiquitinated TDP-43, the protein product of TARDBP, have been observed in surviving neurons for $90 \%$ of patients [89]. However, such inclusions were also present in individuals without genetic mutation. In patients with FUS or SOD1 mutations, these two respective proteins have instead been found to form aggregates. The genetic components and aggregated proteins together indicate that impaired RNA metabolism potentially lead to abnormal protein aggregation and that impaired clearance functions could be an underlying cause of disease [89]. Environmental risk factors associated to disease have so far not been highlighted to the same extent as for MS. Nevertheless, increased level of exercise, smoking and exposure to toxins are among those mentioned [90]. Apart from the loss of motor neurons, neuropathological changes in other brain regions have also been observed and approximately 15\% of ALS patients are also suffering from frontotemporal dementia (FTD) [89].
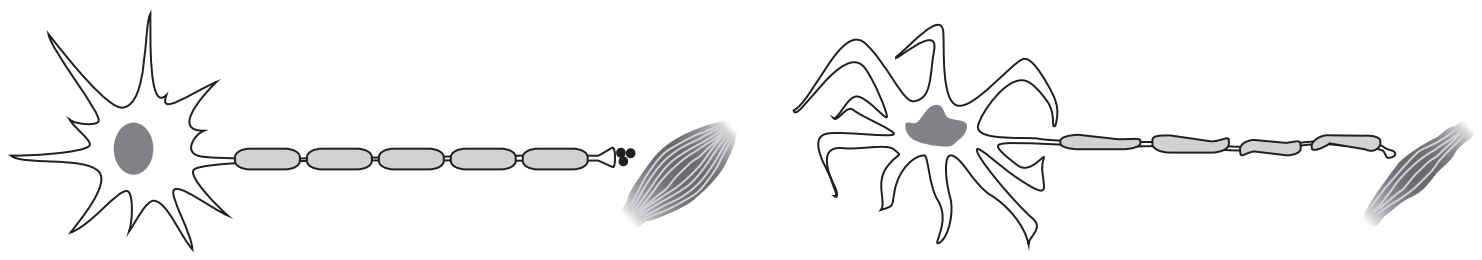

Figure 6: In ALS, loss of motor neurons result in muscle weakness.

The onset of ALS is characterised by limb dysfunction for $65 \%$ of patients (also referred to as classic ALS) [91]. Diagnosis has previously been based only on clinical symptoms of progressive muscle impairment according to the El Escorial criteria [92]. It describes subclassifications of clinically definite, probable or possible ALS, depending on the number of regions displaying UMN and LMN involvement. More recently, the use of neurophysiological technologies such as electromyography, have enabled further characterisation of patients and such analysis is now included in the diagnostic procedure according to the 
Awaji criteria [93]. Patients with pure upper or lower motor neuron signs (PUMN and PLMN respectively) are also observed and although not classified according to the diagnostic criteria, they are often clinically regarded as a form of ALS [94].

\section{Disease associated proteins}

Even though no protein markers are presently in clinical use, several have been suggested based on analysis of body fluids. These proteins mainly reflect the process of neuronal loss and include neurofilaments and TDP-43 [95]. A recent multi-center study reported CSF analysis of seven suggested markers in six independent clinical sample sets and concluded that phosphorylated neurofilament heavy chain $(\mathrm{NFH})$ was the only protein with concordant results between centers [96]. This protein has also been successfully detected at increased levels in blood of ALS patients [97]. Similarly, levels of TDP-43 have been reported as increased in both CSF and plasma [98] [99].

To extend the knowledge on protein profiles related to disease, proteomic technologies have been used for analysis of body fluids in the context of ALS [100]. One of the first reports, by Ranganathan et al, revealed three proteins with altered CSF levels in 23 ALS patients compared to 31 healthy and neurological controls [101]. Two of these, transthyretin and cystatin C, were detected at lower levels in ALS patients. The expression of transthyretin was in the same study also shown to be reduced in spinal motor neurons. Another publication by Pasinetti et al concordantly describes the levels of cystatin C as lower in patient CSF [102]. Instead of comparing ALS patients to controls, Brettschneider and colleagues investigated CSF protein profiles of rapidly and slowly progressing disease [103]. Transthyretin was also there reported as one of the main findings, with higher levels in patients with rapid progression. One study based on multiplex immunoassays of CSF cytokines and growth factors presented a panel of proteins distinguishing ALS from controls [104]. The authors also reported levels of a subset of the suggested proteins as associated to genotype. So far, corresponding reports of plasma have been limited. In Paper IV we addressed this by an extensive plasma profiling study utilising the multiplexing capacity of the suspension bead array assay. We identified three proteins, including neurofilament medium polypeptide (NEFM), as elevated in plasma from ALS patients.

\section{Autoimmune components}

Autoimmune mechanisms have been suggested in ALS due to disease animal models induced by passive transfer of IgG from ALS patients [105]. Increased reactivity to neurofilament proteins compared to other neurological controls have been observed in both 
CSF and serum [106]. One study investigated if autoantibodies towards LRP4, as seen in other disorders affecting motor neurons, were present in CSF and serum of ALS patients. The study revealed that also in ALS, a subset of patients were reactive to this membrane protein important for formation of neuromuscular junctions [107]. These two studies were based on investigations of reactivity to proteins already suggested to be involved in disease pathology. May and collegues instead used a more unbiased approach. They analysed serum IgG reactivity towards more than 9000 full-length proteins in 20 ALS and 20 nondiseased controls and identified 20 proteins displaying increased ALS reactivity, several with CNS related functions [108].

\section{Narcolepsy}

Narcolepsy is a rare disorder affecting the regulation of sleep and wakefulness. It is caused by the loss of a specific type of hypocretin (also called orexin) producing neuron, resulting in a disturbed sleeping pattern [109]. In addition to impaired control of wakefulness, these neurons are also involved in the dopaminergic reward system (Figure 7). Additional symptoms include excessive daytime sleepiness, cataplexy (sudden loss of muscle tone) and hallucinations all of which are thought to be related to the lack of hypocretin [110]. The events leading to this neuronal loss is not yet understood but a strong association of the HLA DQB1 genotype has been interpreted as an indicator of autoimmune involvement. Other genes have also been associated to disease, especially in the few cases of HLA DQB1 negative narcolepsy patients. Several environmental factors have been suggested to be involved, including streptococcal infection, seasonal influenza and toxin exposure. Following the H1N1 influenza vaccination campaigns in several countries, including Sweden and Finland, there was a dramatical increase in the number of reported narcolepsy cases [111] [112] [113]. Mostly children and young adults were affected, but other than a younger age of onset, the clinical phenotype were similar compared to sporadic narcolepsy [114]. Initial hypotheses of the cause included cross-reactivity reactions and molecular mimicry of vaccine or adjuvant components to hypocretin or other neuronal components. However this far, no commonly accepted explanation has been presented. Nevertheless, the induction of autoimmune reactions by adjuvants is a known phenomenon referred to as autoimmune inflammatory syndrome induced by adjuvants (ASIA), indicating that such mechanism may be plausible [115].

Several studies have found levels of hypocretin to be reduced in CSF from narcolepsy patients, especially those with cataplexy [116] [117]. Dauvilliers et al reported for the first time a broad profiling study using a panel of 12 cytokines in a multiplex immunoassay [118]. They analysed both CSF and serum and reported more differences in the blood-based material. However, the low number of proteins significantly altered in CSF might be an 


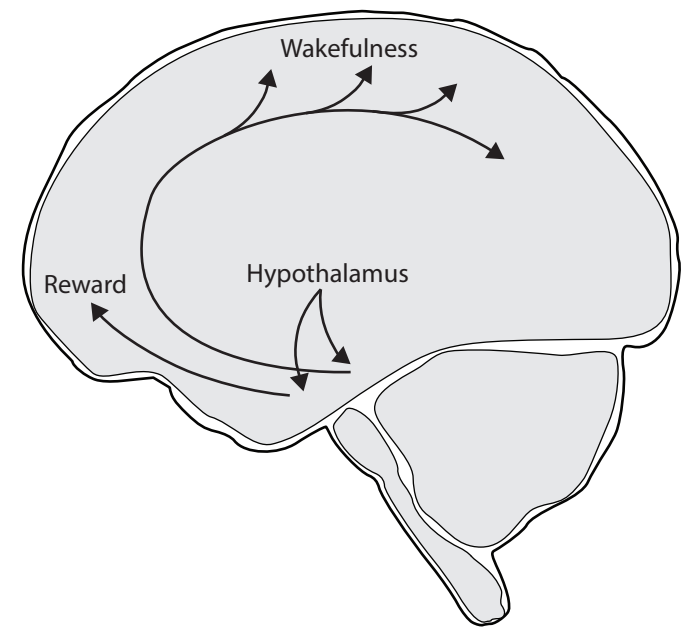

Figure 7: In narcolepsy, hypocretin producing neurons in hypothalamus are lost, resulting in impaired function of the wakefulness and reward systems.

indirect result of the lower number of samples analysed for this body fluid. To my current knowledge, this is the so far only publication reporting a multiplexed protein profiling of body fluids in the context of narcolepsy.

Human IgG purified from narcolepsy patient sera have revealed staining of rat brain sections. In addition, after passive transfer of patient $\operatorname{IgG}$, impaired of sleep regulation has been observed in animal models, suggesting pathological effects of circulating immunoglobulins [119]. In 2010, autoantibodies to tribbles homolog 2 (TRIB2) were found at higher titers in serum of narcolepsy patients compared to other sample groups [120]. TRIB2 is a protein highly expressed in hypocretin producing neurons and levels of reactivity were found to correlate to severity of cataplexy. Antibodies recognising hypocretin have also been reported in serum of patients, however these antibodies do not appear to be disease-specific [121] [122]. In Paper V, we present an autoimmunity profiling study of the IgG repertoire present in serum from Finnish and Swedish narcolepsy patients using 11520 antigens. We reported three protein fragments, representing transmembrane protein 134 (TMEM134), Cytosolic 5'-nucleotidase 1A (NT5C1A) and Methyltransferase-like protein 22 (METTL22), with higher reactivity in narcolepsy patients compared to controls. This finding indicates that reactivity to other proteins than TRIB2 are potentially involved in disease and support further exploration of the autoimmunity repertoire within narcolepsy. 


\section{Alzheimer's disease}

Alzheimer's disease is the most common form of dementia in the elderly population and was described already in the early 20th century [123]. The molecular hallmarks of AD, namely the amyloid plaques and neurofibrillary tangles (Figure 8), were not explained until 70 years later. Then, the amyloid beta precursor protein (APP) sequence was identified and its cleavage into $A \beta$ peptides and subsequent formation of extracellular plaques was described. APP is a transmembrane protein that under normal physiological conditions is cleaved by $\alpha$-secretase to produce a soluble form of APP. Another enzyme, beta-secretase, can also cleave the extracellular APP sequence but creates a longer residual protein than the $\alpha$-sectretase pathway. The remaining membrane bound protein is further processed into peptides of different lengths by a third enzyme, $\gamma$-secretase [124]. One particular peptide, $\mathrm{A} \beta 42$, is considered as the toxic component in $\mathrm{AD}$ plaques and is only produced through the $\beta$-secratase pathway. The second hallmark, referred to as neurofibrillary tangles, is mainly composed of the protein tau. Tau is normally associated to microtubules in neurons, however in AD brains the protein becomes hyperphosphorylated leading to protein aggregation [125]. These two pathological changes are reflected in CSF and can be measured as low levels of the A 342 peptide and increased levels of total and phoshorylated tau [126]. Reports suggest that amyloid plaques represent the initial pathological process, which is followed by neuronal injury [127]. However, clinical trials mainly aiming to reduce the plaque load have so far not been successful in preventing cognitive decline [128].

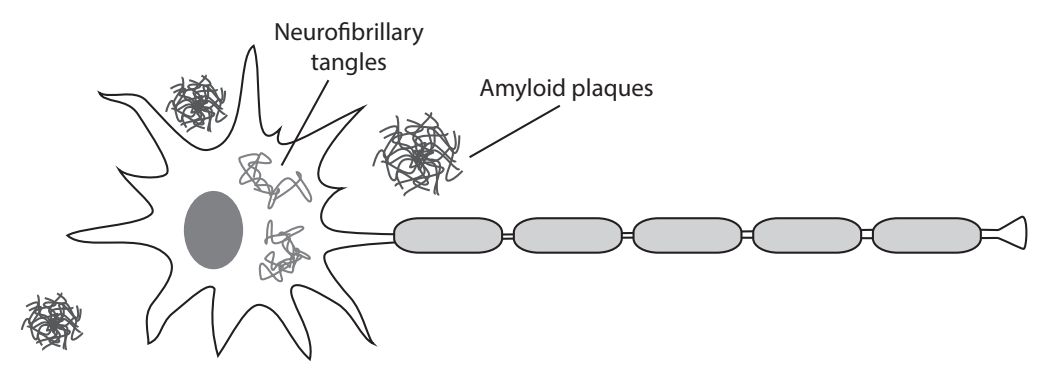

Figure 8: A neuron with the characteristic AD pathology of intracellular tangles and extracellular plaques.

Alzheimer's disease is characterised by memory loss and progressive decline of cognitive function that commonly starts as a condition referred to as mild cognitive impairment (MCI). This term includes patients with mild cognitive dysfunction that have not yet affected daily life [127]. Even though many MCI patients eventually develop AD or other dementias, there can also be other reasons for the cognitive impairment and some patients 
even recover completely. Therefore, many studies have focused on identifying factors that can predict patient outcome, preferentially at an early stage. It has been shown that more severe symptoms, brain atrophy, evidence of plaques and tangles are among those that can predict subsequent conversion into AD. The revised diagnostic criteria for AD presented in 2011 suggested further subcategorisation of MCI patients based on CSF and imaging markers for research purposes [129]. Presence of plaques and tangles have also been observed in asymptomatic individuals and this finding results in limited specificity in the use of CSF protein levels as clinical biomarkers. For this reason, A $\beta$ and tau levels are not incorporated as mandatory in the diagnostic routine [130].

\section{Disease associated profiles}

There is an ongoing debate whether the plaques and tangles cause the degeneration of neurons or if disease process is initiated by other mechanisms. A lot of research has aimed at understanding function and mechanism behind $A \beta$ and tau, for example through identification of additional proteins present in amyloid and tau aggregations [131] [132]. Several studies have also looked beyond these markers in the search of novel disease related proteins. Two reviews published within the last years have comprehensively summarised proteomic efforts aiming to discover blood-based markers of AD [133] [134]. They described protein panels suggested to mediate the discrimination of patients and controls, both using plasma and serum. Kiddle et al recently compiled protein profiling studies performed using multiplex proteomic technologies. They concluded that four out of 163 proteins could be reproducibly described as disease related in samples from five independent collections [135]. These proteins were mainly $\alpha$-1-antitrypsin, $\alpha$-2-macroglobulin, apolipoprotein E and complement $\mathrm{C} 3$. In addition, several others were reported to be reproduced in a lower number of studies. Out of the in total 163 suggested AD markers, the authors performed a large verification analysis of 94 proteins in 677 samples using SOMAmers. They discovered disease related differences for nine proteins, including the four mentioned above. Zurbig and colleagues also compiled a summary of AD protein profiling studies, including a summary of efforts performed using CSF. Various mass spectrometry methods have been employed to identify sets of proteins related to disease. Several have revealed levels of both cystatin $\mathrm{C}$ and $\beta$-2-microglobulin to be altered. Simonsen et al reported a truncated form of cystatin $\mathrm{C}$ as elevated while the full-length form of this protein as well as the levels of $\beta$-2-microglobulin were decreased [136].

Both healthy individuals and AD patients have been described to have circulating antibodies recognising amyloid peptides [137]. In vitro, these antibodies have been shown to be able to clear plaques but the function in vivo is still not known and $\mathrm{AD}$ patients have been found to have higher titers of these immunoglobulins. The involvement of pathological autoan- 
tibodies have also been suggested with potential targets such as gangliosides, lipoproteins and neurotransmittors. Nagele and colleagues investigated autoimmunity profiles of 149 individuals using microarrays with over 9000 human proteins [138]. They reported individual reactivity towards approximately $10 \%$ of proteins and presented ten antigens with ability to distinguish patients from non-demented controls.

\section{Parkinson's disease}

Parkinson's disease (PD) is a movement disorder characterised by loss of pigmented dopaminergic neurons in the substantia nigra [139]. The disease has a gradual onset usually with initial fatigue and stiffness before appearance of the characteristic motor related symptoms of parkinsonism. These include resting tremor of hands or legs, gait disturbances and bradykinesia as well as postural instability [140]. Motor symptoms can be successfully treated by administration of dopamine and parkinsonism has thereby been linked to the loss of dopaminergic neurons. PD is also characterised by the presence of so called Lewy bodies in neurons at multiple areas of the brain [141] (Figure 9). These aggregates are mainly composed of an abnormally modified form of $\alpha$-synuclein, a protein that is normally present in the pre-synaptic terminal. However, these inclusions are not PD specific and can be found in other diseases, for example FTD. Lewy bodies have, similarly to amyloid plaques, also been observed in asymptomatic individuals and their relation to disease progress is yet unclear. Genetic mutations have been discovered as associated to parkinsonism, one of the most commonly observed is the parkin gene [139]. This mutation is associated to motor symptoms but usually not found in PD patients. The three genes mainly associated with disease development are instead a-synuclein, leucine-rich repeat serine/threonine-protein kinase 2 (LRRK-2) and glucosylceramidase (GBA), all related to Lewy bodies but found only in a minority of patients. Examination of aggregates from carriers vs. non-carriers have revealed indistinguishable characteristics possibly indicating a heterogeneous disease mechanism leading to similar phenotypic attributes.

As a component of Lewy bodies, $\alpha$-synuclein has been heavily studied in the context of PD. The protein has been successfully detected in CSF with decreased levels in PD patients reported in several studies [142]. Due to additional expression of this protein in erythrocytes, it has also been detected in blood. Efforts have been made to further characterise protein components of aggregates [143] as well as protein levels in both CSF and plasma, to extend the current knowledge or find novel disease markers [144]. The currently suggested markers in body fluids are, apart from $\alpha$-synuclein, proteins such as DJ-1, Apo A1, EGF and IL-8. DJ-1 levels in CSF have been reported to increase in PD patients and correlate to disease progression. Similar to $\alpha$-synuclein, this protein is also produced systemically and therefore levels in blood-based samples are more difficult to interpret. Levels of EGF and Apo A1 


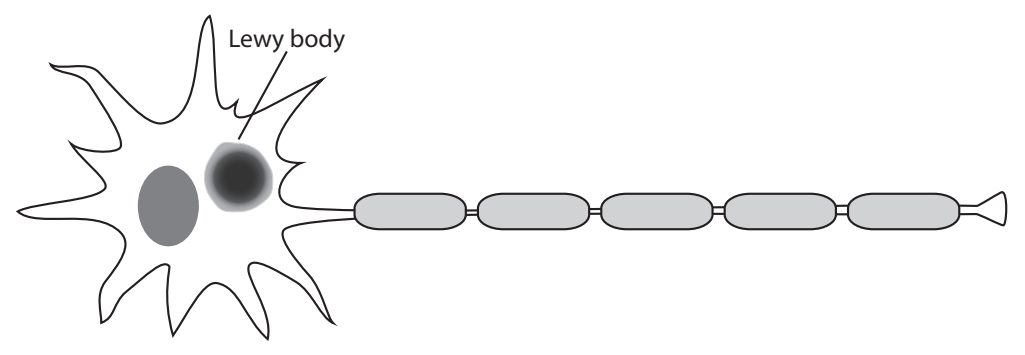

Figure 9: A neuron with intracellular Lewy bodies as found in the brain of PD patients.

have both been investigated using multiplex immunoassays as reported by Qiang et al and Chen-Plotkin et al [145] [146]. These studies revealed protein abundance in plasma to be associated to cognitive function and a predictor of disease development. A proteomic study in CSF published by Abdia et al investigated protein profiles of PD, AD and Lewy body demetia patients to healthy controls to find disease-specific proteins [147]. They concluded that 72 proteins were specifically altered in PD, two of them identified as Apo $\mathrm{H}$ and ceruloplasmin. In 2009, Mollenhauer and Trenkwalder reviewed CSF biomarker discovery studies performed in the field of movement disorders and concluded that all studies performed so far were lacking verification experiments in independent materials [148].

It has been shown that transfer of serum IgG from PD patients have caused destruction of neurons in substantia nigra [149]. Therefore, Han et al analysed the IgG repertoire in a similar manner as reported for AD [150]. In total 120 serum samples from PD, AD, MS and breast cancer patients were compared to 40 controls using over 9000 human proteins. Based on the results, ten proteins were selected to display differential reactivity with higher reactivity frequency in the PD group [150].

\section{Disease commonalities}

Although the disorders described above all have their specific features, many of them share common characteristics such as inflammation, neurodegeneration or neuronal loss. The CNS has been regarded as an immunoprivileged area through the restriction of cell and compound transfer through barriers separating the brain from the systemic circulation. The local innate immune system is mainly controlled by microglia responsible for the first-line defence of infections and clearance of damaged tissues or cells [151]. However, during inflammation the integrity of the blood-brain barrier is disrupted and CNS can be infiltrated by a variety of immune cells [152]. In studies aiming to define disease-specific proteins, inflammatory mediators are commonly included and not seldomly reported among 
the most interesting findings.

In addition to inflammation, degenerative features of disease are also common between several disorders [153]. In MS patients, not only demyelination but also brain atrophy and cerebrovascular impairment have been reported and in AD, brain atrophy is one of the major pathological findings. Extensive atrophy leads to reduced brain volume and thereby an increase in cavities to be filled by CSF. This reduces the turnover rate with accumulation of compounds or altered protein concentrations as potential secondary effects [16]. The process of neuronal loss or damage also releases structural components from cells that can be used as markers of tissue damage. [154]. As one example, light, medium and heavy chains of neurofilaments have been reported as increased in CSF from MS, ALS and AD patients, also with concordant levels in serum [28] [155] [29] (Paper III). Also other common disease markers have been suggested within several neurodegenerative disorders as reviewed by Kroksveen et al [156].

The debate whether inflammation initiates neuronal damage or if injured cells cause inflammation at early stages of disease is a heavily discussed topic [157]. Infections, brain injury and aggregated proteins have been shown to cause activation of the local immune system. Although this activation per se does not cause damage to neurons, it can lead to permeabilisation of the BBB and infiltration of immune cells or autoreactive antibodies [153] [158]. Other studies indicate that an initial event of neuronal damage leads to inflammation as a seconday effect [159]. Regardless of the initiator, it is clear that inflammation has a strong association to neurodegeneration [160]. When extensive tissue damage occurs, as opposed to controlled apoptosis, cellular components are exposed to the local environment [161]. The danger model introduced by Polly Matzinger suggests that dying cells send out danger signals that serve as activators for the immune system [162]. This model could explain the widespread IgG reactivity observed both in healthy and diseased individuals as reported by Nagele and colleagues as well as in Paper IV and V [138]. These results also indicate that individuals with inflammatory conditions display a higher overall reactivity. According to this reasoning, the majority of antibody reactivates would be classified as an epiphenomenon rather than the cause of disease [163]. This hypothesis is in line with the lack of causative and pathogenic evidence reported for anti-myelin antibodies in MS [164]. Nevertheless, autoimmune mechanism have been widely discussed as both the underlying cause and for sustaining disease progress [153]. This hypothesis is supported by the genetic association of several immune related genes to multiple autoimmune disorders. HLA genotype is the major factor identified although it is not sufficient nor necessary for disease development. The relation of EBV infection to MS or H1N1 vaccination to narcolepsy also further implies the immune system to be a crucial component for disease development. 
The above discussed disease commonalities can result in major effects in terms of protein content and sample composition. Proteins related to inflammation or tissue damage can indeed be of value for monitoring disease progression or treatment response, but are perhaps not optimal as disease specific features for diagnostics. The majority of disease related neuroproteomic studies have so far focused on single diseases in comparison with either a healthy control group or patients with other neurological diseases. These other diseases include a wide variety of conditions, ranging from headache to tumours with or without involvement of inflammation. Due to the variety of controls used within neurological research, Teunissen et al put forward a proposal for establishing common criteria and nomenclature for control populations [165]. Their suggestion include discrimination between healthy controls, neurological inflammatory controls, peripheral inflammatory controls and symptomatic controls. To investigate disease specificity of observed protein profiles, multiple disease groups both with and without inflammatory components, BBB impairment and neuronal damage should ideally be included. 


\section{Analytical challenges: From sample handling to individual variation}

The field of proteomics has the potential to contribute to a better understanding of disease mechanisms and to discover proteins for clinical use. However, the difficulty to reproduce published findings is heavily discussed in the field because of the so far low success rate of suggested markers making it into the clinic. A study of lab to lab variation reports that proteomic assay results can vary greatly even though detailed instructions are provided [166]. This observation indicates that variation is introduced by manual sample handling but that such bias can be reduced by good training and standardisation. Nevertheless, there are other sources of bias introduced at different stages of analysis that can affect the study outcome [167] [168]. In the following, relevant factors such as sample preparation, limitations of available technologies and inter-individual variation are discussed. These factors are of importance not only for the field of neuroproteomics but for all efforts aiming to discover proteins associated to disease.

\section{Sample handling and preparation}

Factors related to sample handling and preparation can be divided into pre-analytical and analytical variables. The pre-analytical include selection of sample type, centrifugation and storage conditions while analytical variables are related to the analysis method. Sample depletion, fractionation, dilution and heating are all examples of such parameters (Figure $10)$.

\section{Pre-analytical variables}

The initial aspect of sample handling, also referred to as pre-analytical variables, describes the collection procedure and how samples are treated until storage or further analysis. 


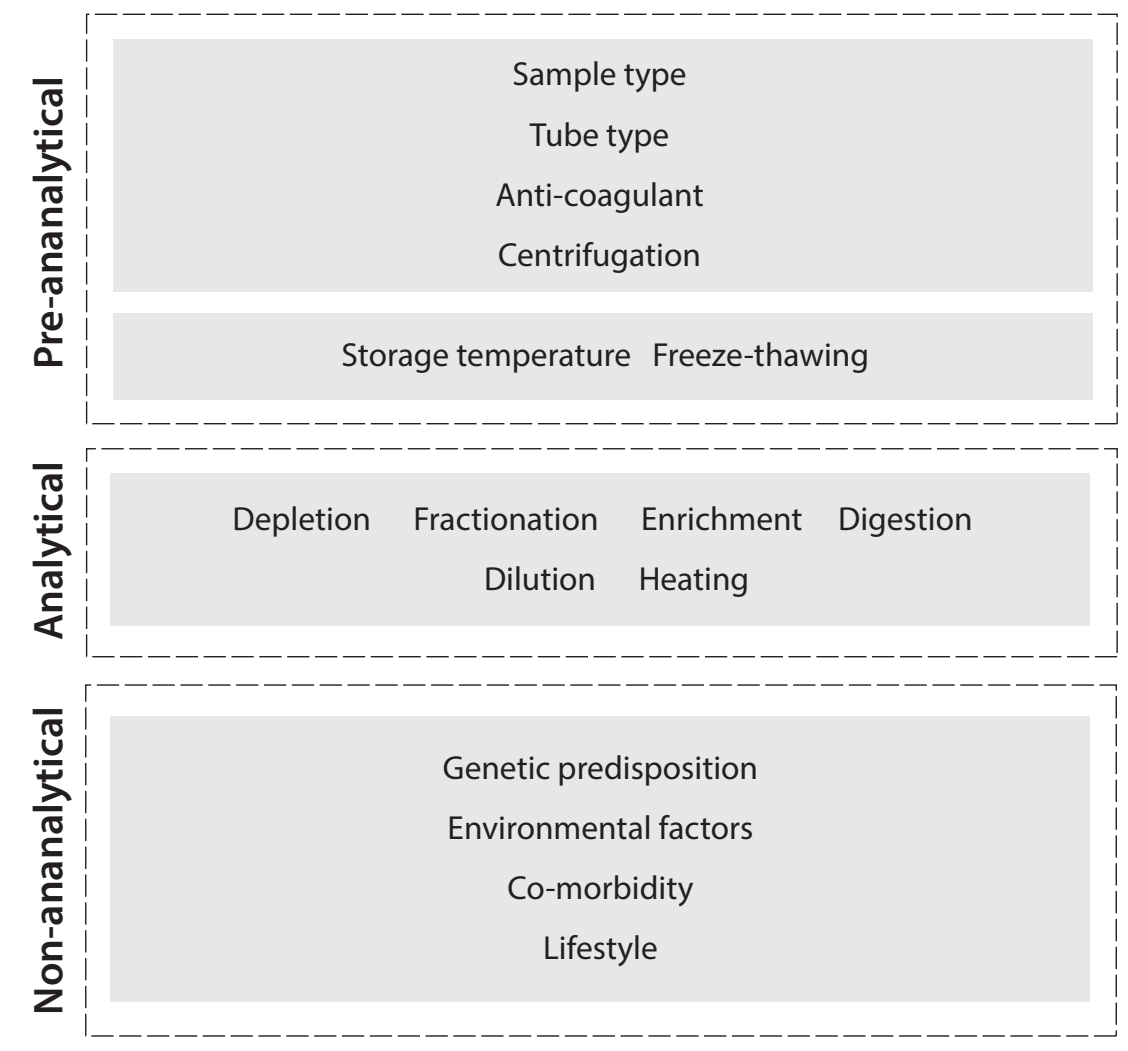

Figure 10: Sample handling and preparation procedures that might affect protein detection can be divided into pre-analytical and analytical variables.

It has been shown that sample type (serum or plasma) together with collection tube, selection of anti-coagulant and the time passing before sample centrifugation are all factors with influence on the detectable plasma proteome. On the contrary, variation in storage temperature and freeze-thaw cycles appear to have minor effects [169] [170]. These findings, reported to be highly protein dependent, were based on mass spectrometry analysis but are also supported by studies using the affinity proteomics approach [171] [172] [173] [174]. For CSF, the majority of proteins appear to be detectable at stable levels based on results from mass spectrometry studies [175] [176]. For this fluid, there is instead a risk of blood contamination during lumbar puncture. This has been shown to not necessarily affect the detection of brain derived proteins but to alter the levels of proteins partially or mainly derived from blood. [53] [177]. Due to the increased awareness of these effects, guidelines and standardisation protocols for sample handling are emerging [178] [166]. In addition, central organisations such as the International Society for Biological and Environmental Repositories (ISBER) have delevoped protocols for documentation of the most critical preanalytical parameters as summarised in the Standard PREanalytical Code (SPREC) [179]. 
Analytical challenges: From sample handling to individual variation

The published reports on protein stability indicate that the majority of proteins appear to be relatively stable both when detected by mass spectrometry and affinity based methods. Nevertheless, due to the observed protein to protein variations, this subject requires further exploration before general conclusions can be drawn.

\section{Analytical variables}

Apart from pre-analytical variables, the analysis outcome for a given sample prepared in a certain way can still vary depending on several sample preparation parameters, also referred to as analytical factors. These include altered sample composition by depletion, fractionation or enrichment and sample treatments such as dilution, enzyme digestion or heating. In shotgun mass spectrometry analysis for example, high abundant proteins are commonly depleted using e.g. affinity columns [180]. Although such procedures are required for this method to detect proteins of low abundance, they potentially also affect the detection of other proteins [181] [182]. It it likely that additional proteins are co-depleted either in the form of complexes with high abundant proteins or through interactions with column components. So not only is the original composition of samples altered, but proteins potentially reflecting disease might be lost in the process.

In addition to depletion, sample digestion is a common sample preparation procedure in mass spectrometry based studies. The majority of information currently available about proteins and proteomes has been generated using this technology and the absolute majority of these studies used trypsin for digestion. The selection of this enzyme for conversion of proteins into peptides can almost be considered as standard procedure, although there are other alternatives. In one study comparing protein abundance as generated by not only trypsin but also chymotrypsin, Lys-C and Lys-N, a positive correlation was observed for enzymes with similar digestion patterns. However for enzymes with different cleavage preferences, the results varied greatly. [183] A study in CSF also revealed similar results and concluded that a combination of several enzymes generated the best coverage of protein sequence [184]. Based on these observations, the plasma and CSF proteomes as described today are biased favouring proteins suitable for trypsin digestion and there are most likely new proteins to explore with other approaches.

The procedure of sample preparation often needs to be adapted depending on the type of analysis to be performed. In mass spectrometry-based methods, depletion and digestion of proteins are commonly applied while for affinity proteomic approaches, dilution factors, buffer components and heat treatments are of importance. For antibody suspension bead arrays, direct labelling of samples enable highly multiplexed protein profiling using antibodies as affinity reagents. In these assays a dynamic range of more than three orders 
of magnitude is commonly observed, although largely depending on the antibody-antigen interaction [30]. Dilution factors are optimised to enable detection of proteins within the dynamic range, however in such multiplexed analyses, optimal conditions cannot be applied for all included analytes. Another analytical parameter used in these assays are heating of samples. It is performed for epitope retrieval, a process believed to enable epitope exposure by alteration of native protein structures. The effect of this treatment is highly antibody dependent, but it has been shown to increase the detected signals for the majority of antibodies generated within the Human Protein Atlas (HPA) in both plasma [30] [185] [186] and CSF (Paper I). Protein profiles generated with this technology are also affected by parameters such as buffer composition.

In other words, sample handling and preparation procedures might alter protein composition or representation to such extent that disease related profiles cannot be found. In studies related to neuroscience where proteins originating from CNS can be assumed to be present at low levels, it is important to be aware of the effects of sample processing and to keep the preparation procedure to a minimum. Even though the plasma proteome with its impressive dynamic range poses a great challenge in terms of detectability, there are emerging methods also in the field of mass spectrometry where human plasma can be analysed without depletion [187]. Also, to reduce the impact of manual handling, methods for sample preparation performed in a single step are developed [188]. Although the latter has so far been applied to cell lysates, it clearly paves the way for future analysis of also other sample materials where extensive sample preparation is required.

\section{Limitations of technologies and assay systems}

As mentioned above, sample preparation procedures vary depending on the method of analysis. In addition, every technology comes with its advantages and tradeoffs in terms of throughput, multiplexing capacity, robustness and sensitivity. In addition to providing a framework for study design, the method of choice also influence result characteristics and consequently the conclusions that can be drawn based on the study outcome.

In mass spectrometry, protein detection is commonly mediated through mapping of detected peptides. By increasing the number of unique peptides required for protein identification, the certainty of correct identifications can similarly be increased. This technology has the advantage of potentially analysing thousands of proteins in one assay, however with a tradeoff in respect to limited sample throughput. Currently, isobaric labelling strategies allow up to ten samples to be analysed in one assay and multiple assays can be performed to increase the sample size. Another drawback is the extensive sample processing procedures required for detection of low abundant proteins. The time spent on reducing sample 
complexity can however be shortened for targeted mass spectrometry analysis by SRM assays. In such analysis, the number of analytes are instead pre-selected and limited and protocols have been described for both plasma and CSF analysis [189] [187] [190] [191]. Despite less extensive sample fractionation, this method has higher sensitivity compared to shotgun approaches and has shown comparable limits of detection as established sandwich immunoassays [192] [193] [194]. For affinity-based methods, new technologies have emerged enabling single molecule detection either using beads and femtoliter microtiter plates [195] or molecular counting of detection antibodies in a capillary system [196]. Both these technologies however so far only measures one analyte at the time and, as is also the case for many sandwich ELISAs, require larger sample volumes than direct labelling based protocols.

In contrast to methods with single molecule detection, affinity-based technologies using a single binder and direct labelling approach have the great advantage of multiplex analysis of both samples and analytes. However for these assays, the greatest challenge is to evaluate antibody selectivity. This can be achieved through development of sandwich immunoassays or by immunocapture approaches with mass spectrometry-based readout [186]. An alternative is to use several independent antibodies for the same target in parallel in the single binder setup and evaluate the correlation of antibodies as an indication of antibody selectivity. Multiple antibodies can also be combined in methods such as sandwich or proximity ligation assays where more than one binding event is required. Because of this, such assays are generally regarded to have an intrinsically higher specificity.

In efforts analysing the proteome or investigating disease related profiles, protein detection is mediated through either peptides or interactions with antibody epitopes. In body fluids such as blood and CSF, truncated forms of proteins and endogenous peptides are also present. These might provide valuable information, like for example the A $\beta$ peptide within AD [197]. In CSF, endogenous peptides have been identified as originating both from high abundant and neuronal proteins of both soluble and membrane bound character [198] [56]. By expanding the detection of a protein to be based on several peptides for mass spectrometry analysis and similarly, multiple reagents in affinity proteomics, it is possible to reveal additional information of the protein or its fragments. Fragments can on the other hand also pose a challenge for technologies requiring multiple binding events to occur and a lack of signal could be misinterpreted as protein absence.

The presence of protein fragments as well as modified proteins can affect analysis outcome regardless of the technology used for analysis. Similarly, the representation of proteins for analysis of antibody reactivity can greatly influence the interactions detected. Autoantibodies to modified proteins have been identified for example within the field of rheumatoid arthritis [199] and in assays based on unmodified proteins, these reactivates are conse- 
quently not observed. Differences in reactivity to full-length proteins and fragments or peptides have also been reported. In one study, reactivity towards the full length versions of myelin proteins MBP and MOG were found to be similar in MS and OND patients. In the same study, reactivity to certain peptides was on the contrary found to be differentiating between sample groups [79]. Similar results were observed for antibodies towards aquaporin 4, also in the field of MS, where patients negative in a cell based assay showed reactivity to the protein when represented by peptides [200]. Epitope mapping efforts have been performed using peptide arrays, revealing the minimal sequence required for interaction [201] [202]. How well this reactivity translates into recognition of a full-length and native protein as present in a biological system was discussed recently by Forsström and colleagues [203]. They showed that reactivity to peptides with sequences present in multiple proteins did not translate into reactivity to all the corresponding larger fragments.

\section{Inter-individual heterogeneity}

Any given protein assay of samples identically collected and analysed from a group of individuals will most likely display a variation in the obtained protein levels. The ultimate aim in studies investigating disease related profiles is to discover proteins that accurately can diagnose or predict disease development. In an ideal case, the protein should be able to classify patients with $100 \%$ specificity and $100 \%$ sensitivity. In reality however, finding such protein markers has proven to be difficult. In most studies, variation in protein levels are observed between individuals within a sample group. In addition, there is commonly also an overlap in levels of different sample groups, even for analytes reaching statistical significance.

In addition to diseased states, genetic predisposition, environmental factors and lifestyle also affect the physiological state of our bodies. These parameters can be summarised as non-analytical variables and have in common that they are not controllable at the time of analysis (Figure 10). There have been efforts initiated to evaluate the association of such non-analytical variables to protein levels in addition to disease associated changes [204]. Enrot and colleagues presented a study based on 92 proteins in more than 1000 samples from a population-based cohort. They reported that up to $56 \%$ of variation in proteins levels could be explained by non disease related factors such as lifestyle.

Efforts within the field of genomics have identified genes and single nucleotide polymorphisms (SNPs) associated to both ethnic populations and disease. In recent years there has been a growing interest to also understand how our genes influence protein abundance. The identification of so called protein quantitative trait loci (pQTLs) have so far revealed more than hundred genes related to the level of certain proteins [205] [206]. Genetic predis- 
position is not only proposed to affect protein levels but also to alter molecular properties through for example the paratopes of T-cell and B-cell receptors. HLA genotype has been suggested to affect the T-cell receptor population and some alleles have even been associated to recognition of certain peptides [207]. In addition to genetic variation, both T-cell and B-cell receptors are assembled through a process referred to as $\mathrm{V}(\mathrm{D}) \mathrm{J}$ recombination, generating an impressive diversity of receptor specificities. This process explains how even genetically identical individuals can differ in their ability to recognise certain antigens. Bcell receptors can be expressed in both a membrane bound and soluble form and the soluble format is equivalent to what we generally call antibodies. Their natural function is to protect the body from invading pathogens through either activation of the complement system or of other effector cells. Antibodies reactive to human proteins have been investigated in the search for disease related autoantigens however, at the time of writing, there are no systematic efforts published addressing antibody specificities in a healthy population. The reactivity patterns observed in Paper IV and V, as well as reported by others [138], indicate an extensive inter-individual variation in terms of reactivity. This heterogeneity further complicates the search for disease-specific profiles and emphasise the importance of large sample sets in studies with such aim.

The two non genetic factors most widely discussed as potential confounders in protein profiling studies are age and gender. Hormonal levels such as oestrogen and progesterone are inherently related to gender and these have been shown to have secondary effects on protein expression [208]. Also in autoimmune diseases in general, there is a bias towards higher prevalence among women [209] [210]. One hypothesis of the underlying mechanism is involving the process of $\mathrm{X}$ chromosome inactivation that occurs in females. If this inactivation is skewed resulting in expression of a slightly altered protein, it could cause failure in recognition of self and thereby activation of the immune system [211]. Parkinson's disease on the other hand affects more males than females. In this disease, even the clinical characteristics vary between genders possibly due to the protective effect of oestrogen on dopaminergic neurons [212]. The ageing brain is characterised by reduced brain volume also for individuals without neurological symptoms [213]. As mentioned above, a secondary effect of brain atrophy is increased ventricular space and thereby CSF volume. Several studies have been performed to evaluate the age related changes of protein levels in CSF and concluded that the majority of proteins are present at stable levels [54] [214]. Proteins identified as changing were found to be involved in inflammatory processes and response to injury [215].

Inflammatory processes can, in addition to ageing, also be induced by other diseases. Throughout life, all humans encounter numerous infections and various diseases that can induce an inflammatory response. Individuals included in medical studies, both as patients and healthy or diseased controls, are often well characterised and selected based on specific 
inclusion criteria. However, studies of disease related proteins such as $A \beta$ and tau in $A D$ indicate that pathological protein patterns are present long before onset of clinical symptoms [216]. This highlights the possibility that individuals currently displaying symptoms of a certain disease potentially also are in pre-symptomatic stages of others that could affect their protein levels.

As discussed above, genetic variation, age, gender and other non-analytical variables can affect the levels of proteins present in our bodies. The diseases discussed in this thesis can all be regarded as complex as the patient populations are heterogeneous in terms of for example genetic background, clinical phenotype and disease progression. In most complex diseases, patients are further subclassified as a way to assess this diversity. For example within ALS, family history is used to assign patients as either FALS or SALS. Furthermore, among FALS patients, several different genetic mutations have been associated to disease. The role of these genes and their products in disease development have not yet been understood but the involvement of several genes perhaps suggest different underlying molecular mechanisms even within this subgroup of patients. Detailed stratification according to available information can be used to form well defined subgroups of patients. However, further sub-classification of subjects result in smaller sample groups and consequently, larger sample collections are required to also take into account the non-disease associated variation in protein levels.

The majority of studies currently performed aiming for discovery of diagnostic markers are based on retrospective materials with samples collected at a time point reflecting diagnosis rather than disease onset. In such studies, analysis of samples obtained in the present aims to elucidate the events in the past related to development of disease. Prospective studies offer an alternative approach where individuals are followed over time with repeated sample collections. Such population based longitudinal studies have been initiated for epidemiological purposes but also for genomic, transcriptomic, metabolomic and proteomic investigations. One Swedish initiative is the LifeGene study in which 500000 individuals will be followed and samples collected together with information on environmental exposure and lifestyle factors. This longitudinal sampling strategy offer a unique possibility to not only follow patients over time, but also to provide sample material collected before disease onset thus serving as individual baselines. Through the emerging protocols for standardisation of sample collection and collaboration with established biobanks, these sample collections will most likely be important contributors of future disease related research. 


\section{Present investigations}

The work presented in this thesis is based on protein profiling of human body fluids using affinity reagents and microarray technologies. In the field of neuroscience, analysis of not only plasma or serum, but also CSF, is of interest for discovery of disease related protein levels. Therefore, the main aim has been to establish analytical protocols for profiling of human samples on microarrays and to apply these protocols within several disease areas.

The availability of reagents is often a limiting factor in affinity proteomic studies. To meet the needs of the research community, there are several initiatives aiming at large scale production of antibodies and other binders. One such initiative is the Human Protein Atlas project, which since 2003 has worked towards generating antibodies to all human proteins [217]. The production pipeline is initiated by selection of a gene sequence corresponding to 50-150 amino acids with low homology to other human proteins. This sequence is cloned and expressed in $E$. coli as a protein fragment fused to a hexahistidine tag and an albumin binding domain. The tag is used for protein purification and the resulting product immunised into rabbits for generation of polyclonal antibodies. Antibodies are retrieved through affinity purification using the same antigen as for immunisation and referred to as monospecific antibodies. Antibody selectivity is evaluated through antigen microarrays where 384 antigens, one of which is the fragment used to generate the antibody, are printed on planar glass slides. These arrays are continuously produced using new sets of antigens to match the antibodies sequentially generated within the project. Antibody validation is followed by analysis of proteins in human normal and cancerous tissues as well as cell lines in order to create an atlas of human protein expression. The current version, v.13, holds over 24000 antibodies together covering $83 \%$ of the human protein encoding genes. This atlas represents the first draft of the tissue-based human proteome as investigated by an affinity proteomics approach.

The antigens and antibodies produced within the Human Protein Atlas are valuable tools for protein profiling of human body fluids. Protein levels in plasma, serum or CSF can be 
investigated using the antibodies in combination with the suspension bead array technology. Also, the antigen arrays produced for antibody validation offer a platform for screening of antibody reactivity in a high-throughput fashion (Figure 11). These tools were utilised in all papers included in this thesis, as described below.

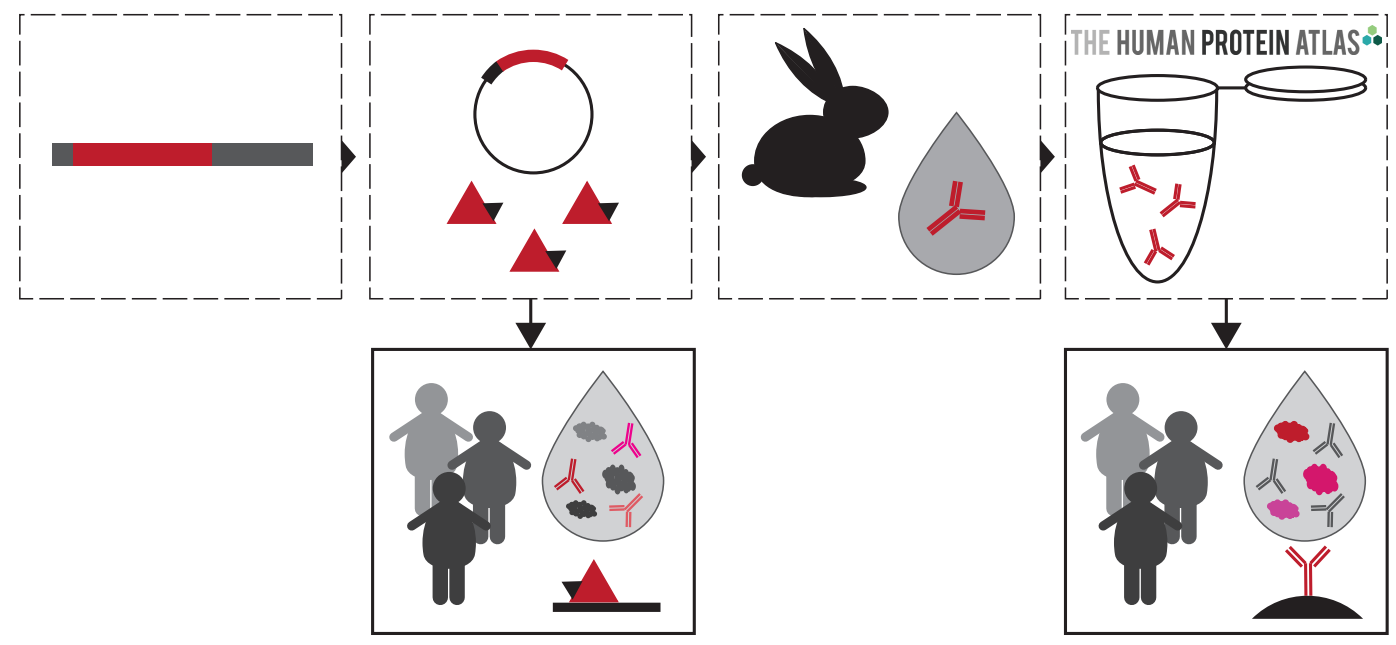

Figure 11: Overview of the Human Protein Atlas workflow and the use of the reagents for profiling of human body fluids.

For protein profiling, antibody arrays can be generated using the suspension bead array technology and up to 384 analytes analysed in parallel. Through the use of microtiter plates, this approach allows for profiling of 384 samples in one assay while only requiring a few microliters of both plasma, serum and CSF. The possibilities for multiplexing in terms of both analytes and samples are obtained through a single binder assays combined with a direct labelling approach. The beads used are magnetic, colour-coded microspheres containing three internal fluorescent dyes. The ratio of these dyes determine the identity of the bead and each identity is assigned to a specific antibody. After immobilisation, all bead identities are mixed, thereby creating a bead array in suspension. The samples to be analysed are prepared by dilution and protein content labelled using biotin. After a second dilution, the labelled samples are heat treated before incubated with the bead array. This heat treatment procedure appears beneficial in the single binder setup, potentially through disruption of protein structure resulting in epitope exposure. After incubation, unbound proteins are washed away and interactions detected through a streptavidin conjugated fluorophore. The relative intensities obtained are displayed as median fluorescent intensity (MFI) and subjected to statistical analysis in order to evaluate protein profiles associated to disease (Figure 12A).

Screening for specificities of circulating autoantibodies is possible through utilisation of 
antigen microarrays. Autoimmunity has been suggested to both cause and mediate disease progress in several disorders, however for the majority, the autoantigen has not yet been discovered. The antigen arrays produced within HPA offer tools for high throughput screening of antibody interactions using less than one microliter of plasma or CSF for each batch of 384 antigens. In this setup, diluted samples are incubated with the planar microarrays and interaction detected by a labelled secondary antibody. Reactivity is defined by application of sample specific cutoff levels and the reactivity frequency in different sample groups compared (Figure 12B). The planar arrays are produced in such format that 21 samples can be analysed on one slide. Screening of antibody repertoires is usually performed in 80-160 samples resulting in selection of a subset of interesting antigens. These antigens are then immobilised on beads and reactivity in a larger sample material analysed using the bead array technology.

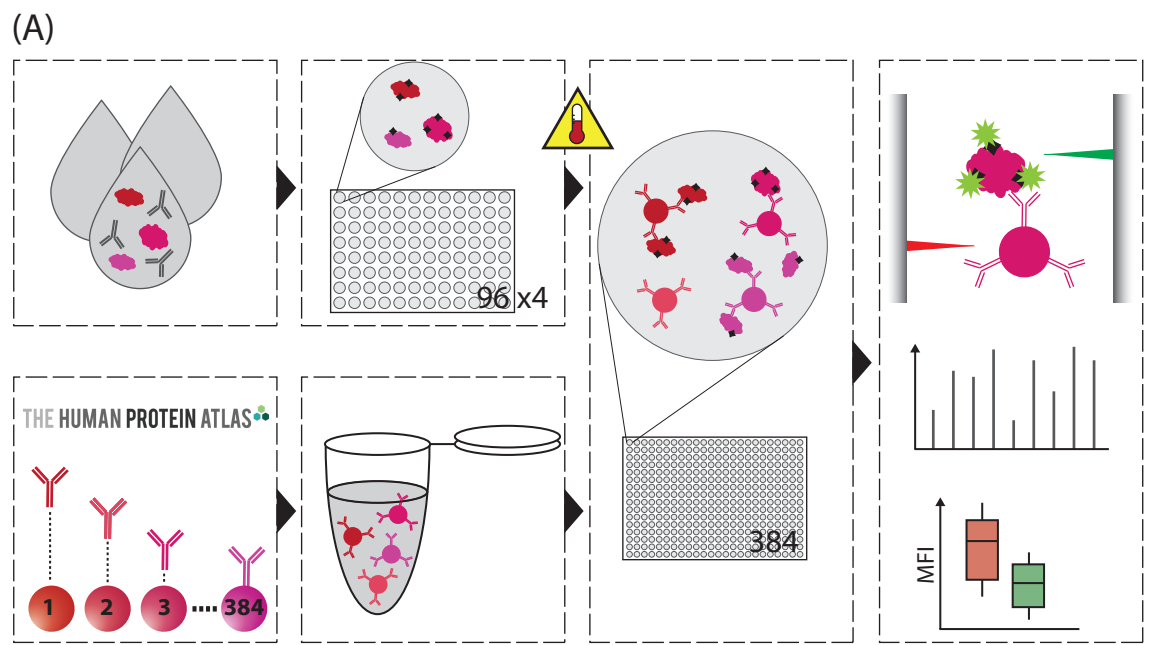

(B)

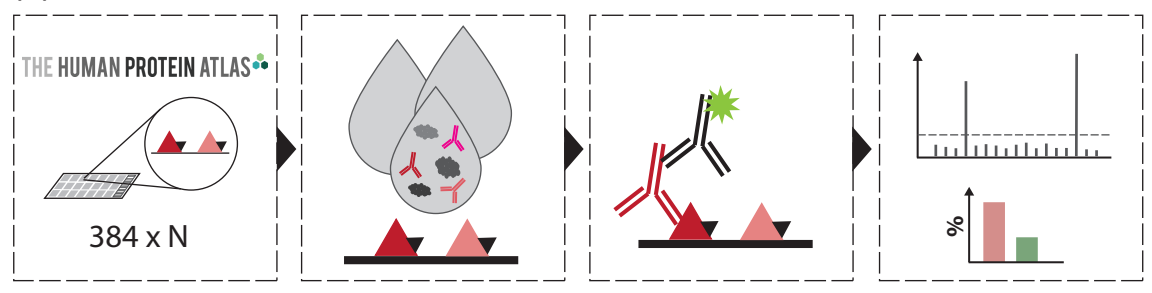

Figure 12: (A) Protein profiles of human body fluids are generated by direct labelling of samples and a single binder assay. (B) Autoreactive antibodies are detected using antigen microarrays and a labelled secondary antibody.

The papers presented here have all utilised the multiplexing capacity of the above described array technologies for profiling of proteins and antibodies in human body fluids. 
As discussed in the previous chapter, analytical challenges such as sample handling and individual variation can influence the results obtained in profiling studies. Below, the five papers included in this thesis are described together with the challenges faced while performing this work.

\section{Paper I: CSF protein profiling within MS}

Cerebrospinal fluid, as a proximal fluid, potentially contains valuable information of the physiological status of the brain. This fluid is routinely collected as a part of the diagnostic procedure for several diseases, including MS. Therefore, the suspension bead array technology that previously was used for protein profiling of human plasma and serum samples [174] was now adapted for analysis of proteins present in CSF. The developed protocol was then applied to perform protein profiling of samples from an MS cohort, including several MS subtypes (RRMS, SPMS, PPMS) as well as patients with other inflammatory and non-inflammatory neurological diseases (iOND, OND). Assay development was performed using 65 samples and 71 antibodies targeting 69 proteins with potential disease relevance. An extended set of 339 samples were analysed for verification of the initial findings.

\section{Assay development}

As a starting point, CSF samples were analysed according to the plasma profiling protocol with minor adjustments in dilution factors. The results revealed a higher median intensity for all antibodies in MS patients compared to controls. To evaluate whether this observation was a result of analysing only disease related proteins, a set of 384 non-selected antibodies sequentially produced within the Human Protein Atlas was used. This analysis revealed a similar result, indicating the presence of a systematic bias in the obtained data. At this stage, the data was further related to clinical information, revealing a positive correlation between signal intensities from the bead array and $\operatorname{IgG}$ quotient. IgG quotient reflects the levels of IgG in CSF compared to blood and is used as indication of intrathecal production of antibodies as frequently seen in MS patients. Also, the corresponding information on albumin quotient suggested the levels of albumin to be related to intensity levels in the protein profiling assay. This bias was probably caused by interactions of the high abundant proteins to the beads or immobilised antibodies. To reduce this effect, the PBS dilution buffer used at labelling was supplemented with bovine serum albumin (BSA) and rabbit $\operatorname{IgG}$ at concentrations higher than the total protein concentration of samples. This adjustment reduced the systematic effect and revealed a result where the majority of proteins were observed with similar levels in MS patients and controls (Figure 13). A 
spike-in experiment was conducted to evaluate the effect of these additives in terms of limit of detection, revealing no apparent loss of sensitivity.

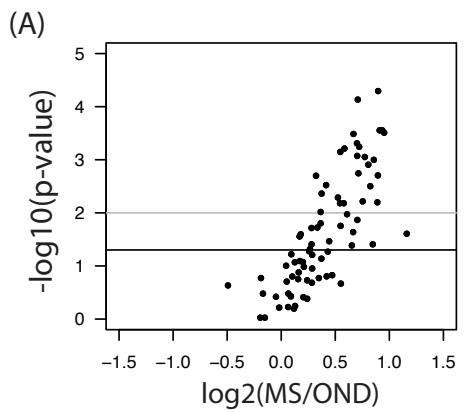

(B)

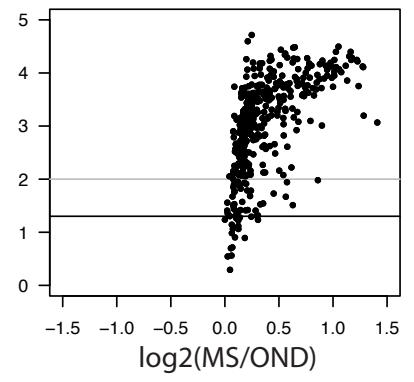

(C)

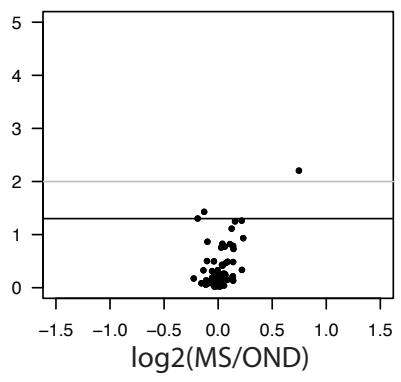

Figure 13: CSF samples labelled in PBS indicated a systematic bias in protein profiles obtained, with higher levels for all antibodies in MS patients both using (A) a targeted 71plex and (B) a non-targeted 384plex bead array. (C) Supplementing the labelling buffer with BSA and IgG reduced this bias and the majority of antibodies revealed no difference between sample groups.

The effects of heat induced epitope retrieval on protein-antibody interactions were also investigated by treatment of samples at 56 and $72^{\circ} \mathrm{C}$. The results showed generally higher intensities for the higher temperature, however with highly antibody-dependent patterns. To evaluate this effect further, both temperatures were used for profiling of the extended sample material.

\section{Disease related protein profiles}

Based on the initial results from analysis performed during assay development, 43 proteins were selected for further investigation. In single binder assays, detection is mediated by one antibody and therefore, this format has inherent lower specificity compared to for example dual binder assays. The reported intensity from a single binder assay can not be used to distinguish between on-target protein capture, the capture of a protein in a complex or the off-target interaction for example in absence of the intended protein. One way to come about this is to use multiple independent binders towards the same protein in parallel or, alternatively, to combine such binders into dual binder assays. In this study, several antibodies targeting the same protein were included in the single binder analysis and their correlation evaluated to increase confidence of the protein profiles observed. After analysis of all 339 CSF samples, two proteins of special interest were selected. The first protein, neuromodulin or growth-associated protein 43 (GAP43), was observed at lower levels in 
the most progressive form of disease (Figure 14A). This protein is important for axonal regeneration and has previously been found at lower levels in lesion areas of MS brain tissue. Lower levels of this protein in CSF could indicate extensive lesion activity and inability of regeneration, a feature believed to characterise MS patients with progressive disease. CSF levels of this protein were supported by three antibodies independently generated within HPA. They all showed a highly correlating result in the assay performed at $56^{\circ} \mathrm{C}$, but only one of them appeared as functional in detection of differences between groups with heat treatment at $72^{\circ} \mathrm{C}$. For the other protein with differential protein profiles, $\alpha$ 1-chymotrypsin (or serpin peptidase inhibitor clade A member 3, SERPINA3), the two antibodies used revealed correlating results when analysed at both temperatures. This protein is involved in the acute phase response to inflammation and was found as increased in all MS subtypes as well as in the in the inflammatory controls (Figure 14B). This finding highlights the importance of control group selection and the influence of common disease characteristics.

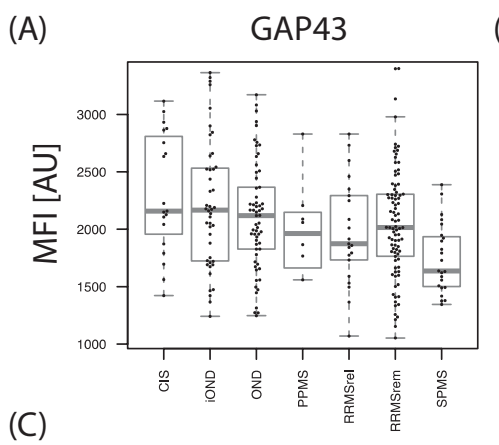

(B)
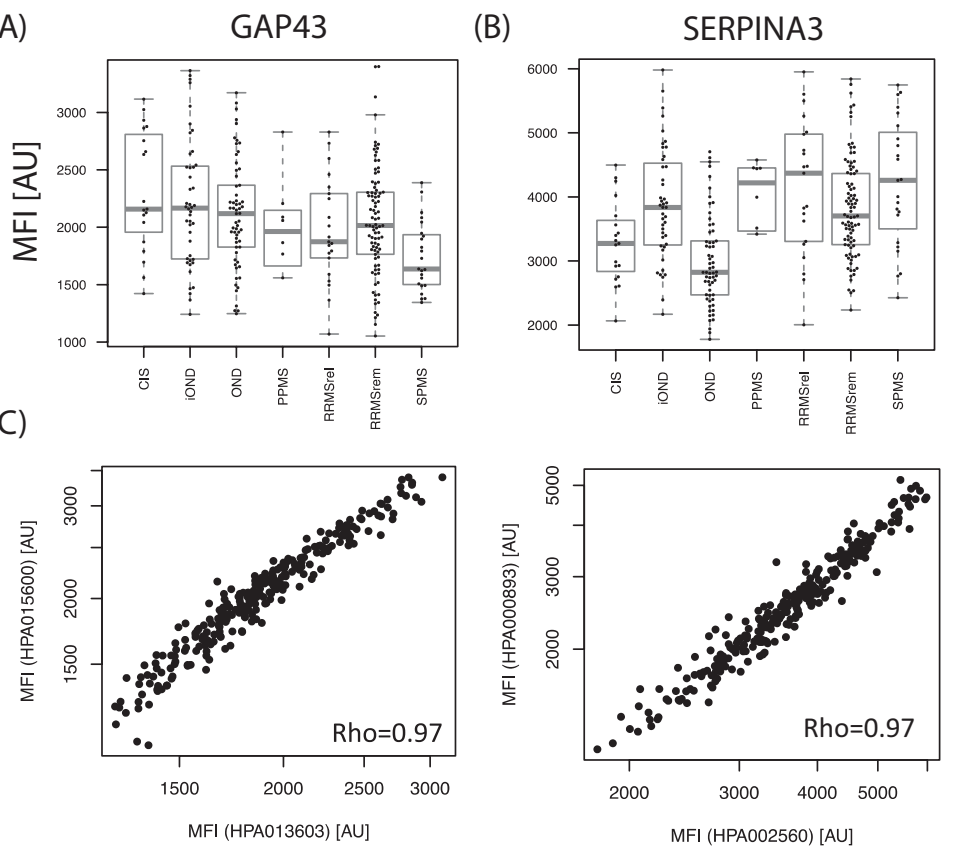

Figure 14: (A) CSF levels of GAP43 were found to be decreased in SPMS patients while (B) SERPINA3, a protein related to inflammation, was observed at higher levels in all MS subtypes as well as inflammatory controls. (C) Several antibodies targeting these proteins revealed highly correlating results.

In summary, a protocol for protein profiling of CSF was developed for analysis using the suspension bead arrays. Compared to the relatively stable composition of blood, IgG and 
albumin levels in CSF can vary in relation to disease and give rise to analytical bias. Here, we showed that this bias can be reduced by adjustment of buffer composition, enabling profiling of also this body fluid with the bead array technology. This method was subsequently applied for analysis of a selected set of 69 proteins potentially related to disease and two proteins, GAP43 and SERPINA3 found to display disease related levels. The established protocol allows for further exploration of proteins in CSF within other disease areas both to evaluate the disease specificity of the two above-mentioned proteins as well as for discovery of novel disease related protein profiles.

\section{Paper II: Antibody-based analysis of plasma, CSF and brain tissue in MS}

In this study, plasma samples from an MS sample collection was the starting point for antibody-based profiling exploring disease related proteins. Initially, antibodies used for analysis with the suspension bead arrays were not selected based on previous knowledge but were included solely based on the continuous production in the HPA pipeline. The antibodies were utilised for analysis of 26 plasma samples from MS patients and healthy controls. The two sample groups were compared and a subset of antibodies selected for further analysis using a larger sample material, also including disease controls in the form of OND and iONDs. At this stage, also antibodies representing previously reported MS related proteins were included, resulting in analysis with 384 antibodies on in total 172 samples. As a next stage of verification, an increased number of both plasma and CSF samples were profiled and the antibodies reported in Paper I also included.

During analysis of plasma samples in the third stage of this study, it became apparent that the levels of some of the proteins were affected by pre-processing procedures. Although considered as one cohort, samples were taken at two hospital sites and collected over several years. The samples were received in several shipments, roughly reflecting collection year. Through principle component analysis of the entire dataset based on analysis with 101 antibodies, the site of collection was identified as the major factor contributing to bias related to pre-processing. Therefore, samples from only one of the hospitals were selected for the final analysis. In addition, the effect of shipment, labelling plate as well as individual information on age and gender were accounted for as covariates in a regression model.

Based on the analysis of plasma and CSF, six proteins were selected for analysis of human brain tissue. Levels of interferon regulatory factor 8 (IRF8) and interleukin 7 (IL7) were both found as decreased in plasma of CIS patients in remission and IL7 levels also elevated in plasma of SPMS patients. Two other proteins, methyltransferase-like protein 14 (METTL14) and solute carrier family 30 family 7 (SLC30A7) were on the other hand 
found to be decreased in SPMS patients. Staining of human brain revealed neuronal staining for IL7, IRF8 and METTL14 while the antibody for SLC30A7 stained blood vessels and microglia. IRF8 profiles in both plasma and CSF as well as tissue staining results are presented in Figure 15.
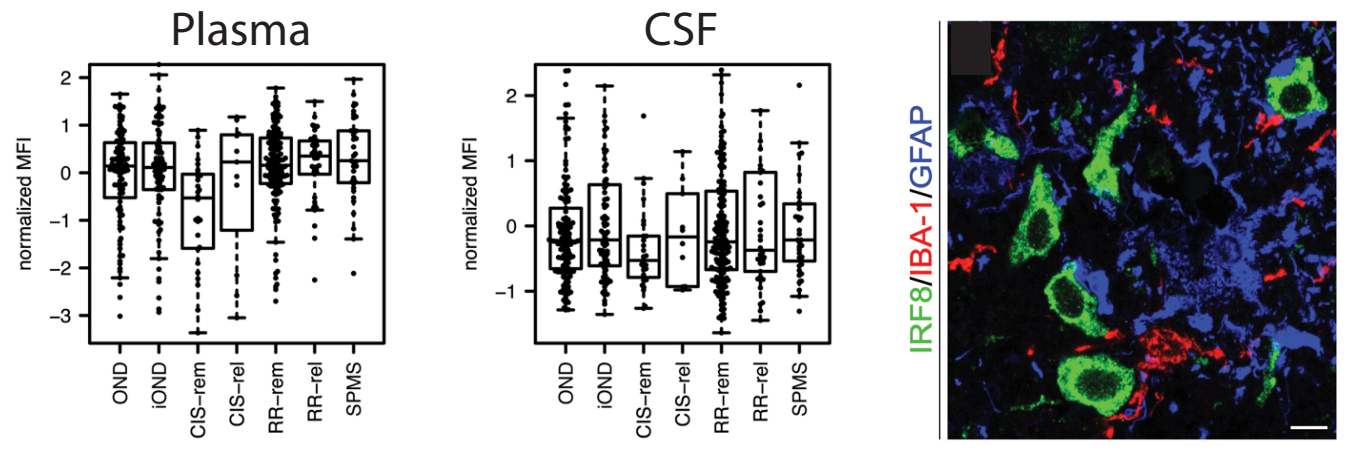

Figure 15: Levels of IRF8 in plasma were found to be lower for CIS patients in remission while no significant differences were observed in CSF. Staining of human brain tissue revealed a neuronal staining pattern. Scale bar: $10 \mu \mathrm{m}$.

GAP43, the protein reported as decreased in CSF of SPMS patients in Paper I, was also in this study observed as decreased in plasma, although only with one of the three antibodies. CSF samples included in this study were partially overlapping with the previously reported analysis, however the additional 234 samples confirmed the already presented finding. The same was concluded for SERPINA3 for which both antibodies again revealed protein levels related to inflammatory characteristics of disease. For this protein, no disease related levels were observed in plasma. Protein profiles for paired plasma and CSF were subjected to correlation analysis but no direct correlation between the two fluids was observed. In staining of brain tissue, the antibody for GAP43 revealed axon-like staining patterns in normal appearing areas of MS brain (Figure 16A). However, in lesion areas, immunoreactivity was reduced, in line with previous publications as mentioned previously (Figure 16B). The antibody for SERPINA3 revealed staining of blood vessels in MS patients while no staining was observed in normal brain (Figure 16C).

This paper describes the use of antibodies for analysis of two body fluids in a study aiming to reveal disease related protein profiles. It demonstrates the use of affinity reagents for both body fluid and tissue analysis. In the initial analysis, a more unbiased approach was taken to analyse proteins without any prior knowledge of disease relevance. Five proteins were found to have disease related levels and staining of human brain tissue revealed expression in both neurons and glial cells as well as in blood vessels. In addition, the findings reported in Paper I was reproduced in an extended sample set. 

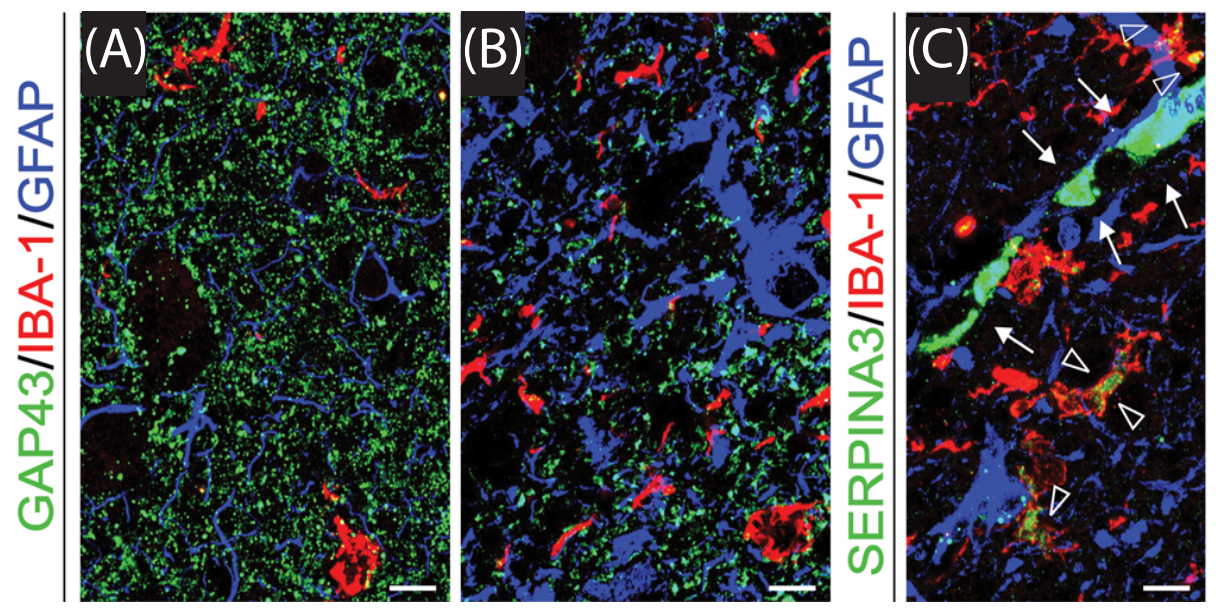

Figure 16: (A) Staining of human brain tissue revealed axon-like staining for GAP43 in normal appearing tissue while (B) immunoreactivity was reduced in lesion areas. (C) For SERPINA3, vascular staining was observed in MS brain but no staining found in normal brain. Scale bars: $20 \mu \mathrm{m}$

\section{Paper III: Disease associated protein profiles in ALS}

ALS is a common motor neuron disease with a yet unknown cause. In this study, we performed plasma profiling using the bead array technology to analyse levels of 278 proteins in 468 samples in the search for disease related proteins. In addition to comparing the observed levels in ALS patients and controls, differences between clinical subtypes according to disease onset and phenotype was subjected to evaluation.

The total set of 468 plasma samples, 367 from ALS patients and 101 from controls, was initially divided into two subsets and analysed using 352 antibodies together targeting 278 proteins in two separate assays. After selection of proteins with concordantly altered levels between sample groups, the entire set of samples was again analysed using a focused bead array including antibodies towards eight proteins. As presented in Figure 17, three proteins were found at higher levels in ALS patients compared to controls. These proteins were neurofilament medium polypeptide (NEFM), regulator of G protein signalling 18 (RGS18) and a member of the solute carrier family 25 (SLC25A20). The levels of these proteins were also analysed in relation to available patient information regarding site of disease onset, clinical phenotype and diagnosis according to the El Escorial criteria. Apart from higher levels in patients classified as definite ALS compared to suspected ALS for NEFM, no significant differences were observed.

In the replication stage of this study, several antibodies towards the eight selected pro- 

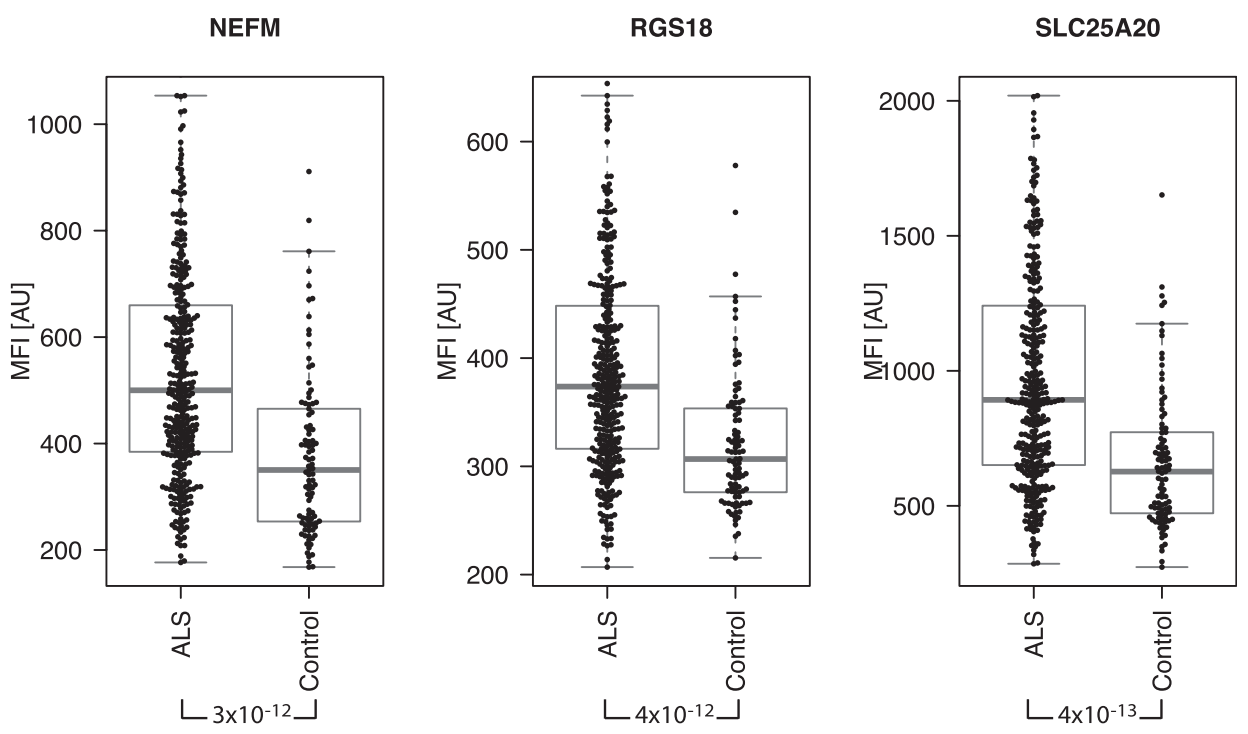

Figure 17: Higher levels of NEFM, RGS18 and SLC25A20 were found in ALS patients compared to controls.

teins were included. For NEFM, RGS18 and SLC25A20, none of the additional antibodies showed correlating results. Instead, they all displayed signal intensities in the range of background noise, indicating that the intended protein target was not captured. The absence of detectable protein could have many explanations, for example epitope unavailability or low affinity interactions. Attempts were also made to set up sandwich immunoassays using the same antibodies, however without successful results. To verify antibody selectivity in this study, Western blot analysis was performed and bands of correct size identified for NEFM and SLC25A20 while the blot with RGS18 detection was blank. Currently, efforts with immunocapture experiments with a mass spectrometry readout are initiated to verify antibody selectivity.

In conclusion, this paper to our current knowledge describes the most extensive plasma profiling analysis within ALS in terms of number of samples analysed. Three proteins were identified as associated to disease, however the levels were generally similar for patients with different clinical features. Through newly established collaborations, these findings are currently evaluated in independent sample materials consisting of both plasma and CSF. 


\section{Paper IV: Profiling the autoimmunity repertoire of MS patients}

In this study, we set out to profile the targets of circulating antibodies present in plasma of MS patients. The major components of myelin have previously been proposed as autoantigens due to the demyelinating characteristics of disease. An observation supporting this theory is that immunisation of myelin components into rodents result in MS-like disease. However, as discussed in previous chapters, even though antibodies towards these proteins are found in MS patients, they have also been observed in diseased and healthy controls.

To discover novel autoimmune targets, we used the antigen arrays routinely produced within the HPA for screening of IgG reactivity in plasma. Initially, 90 samples were analysed for reactivity using 11520 protein fragments. Reactivity was defined by applying sample specific cutoff levels and when summarising the data, a broad individual variation was observed with the majority of reactive antigens observed only in single individuals. Comparison of overall reactivity revealed that higher reactivity both in terms of common antigens and number of antigens was found in SPMS than RRMS patients. Also, the reactivity in the RRMS group was higher compared to patients with other neurological diseases. After extensive data analysis using several approaches to identify differentially reactive fragments, a set of 384 antigens was selected for verification. These antigens were re-printed on planar arrays and analysed using the same sample set. In the third stage, the same 384 antigens were immobilised on beads and an extended set of 376 samples analysed using the bead array technology. Finally, 51 antigens were identified to provide differential reactive patterns between disease groups (Figure 18).

To explore the correlation of reactivity profiles in plasma and CSF from the same individual, paired CSF samples were analysed in the second stage of this study. This analysis revealed that 14 of the 51 antigens showed concordant reactivity in the two body fluids. In addition, the absolute majority of reactivities in CSF were also seen in plasma as indicated in Figure 19 and the antigen with highest concordance was the transmembrane protein anoctamin 2 (ANO2).

As discussed previously, it has been suggested that tissue damage in combination with danger signals can result in breaking of tolerance and autoimmune reactivity. Such damage can be caused by for example demyelination, as occurring in MS, and myelin components as well as other proteins could be in focus of the activated immune system. The heterogeneous reactivity profiles observed in this study pose a challenge in identifying disease related antibodies. This observation highlights the importance of analysing large sample numbers in order to discover reactivity related to disease. Currently, reactivity towards the 51 selected antigens together with targets suggested in literature is further evaluated in an 


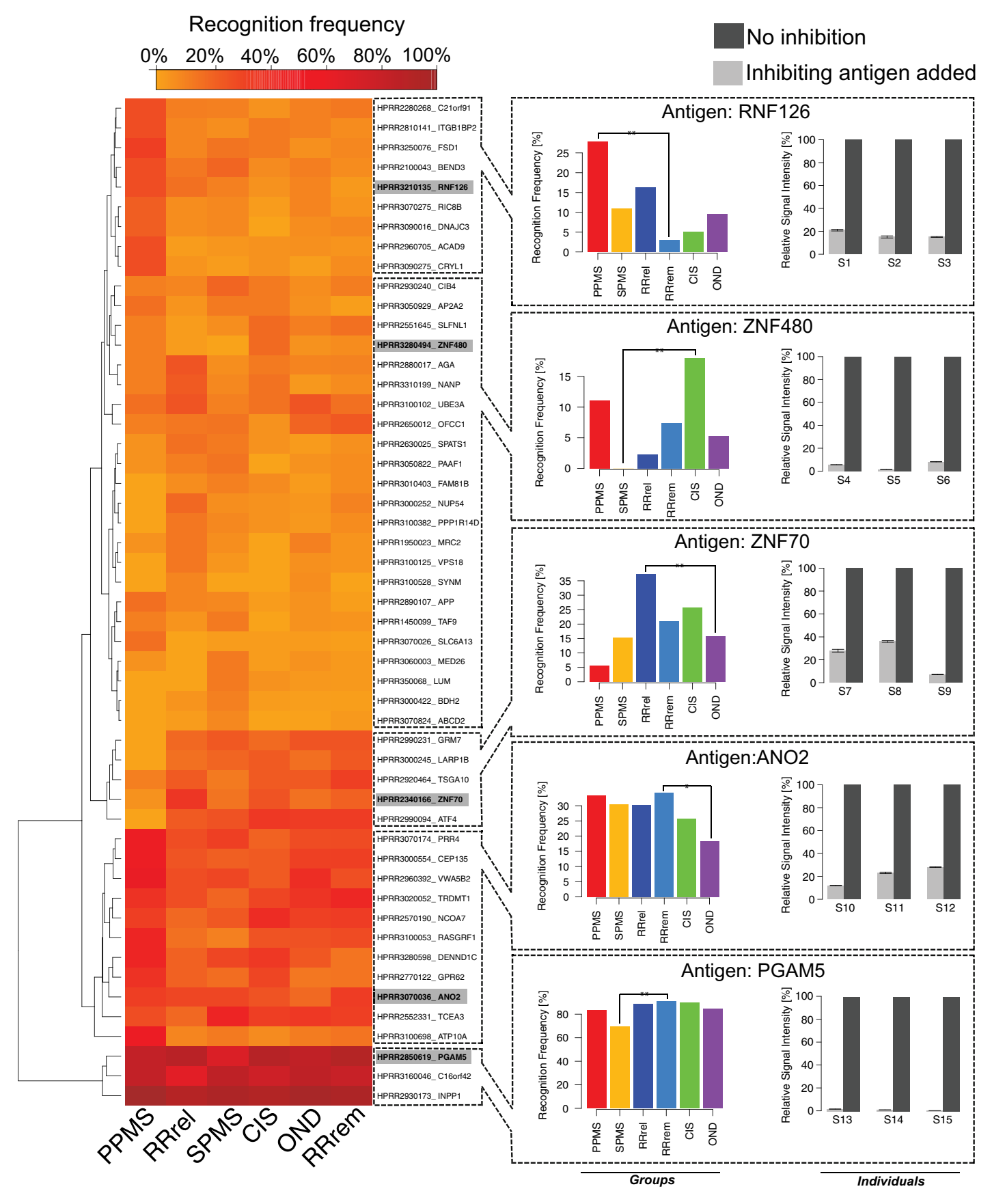

Figure 18: After screening for $\operatorname{Ig} G$ reactivity towards 11520 protein fragments in plasma of MS patients, 51 were selected to be differentially recognised in the sample groups. 


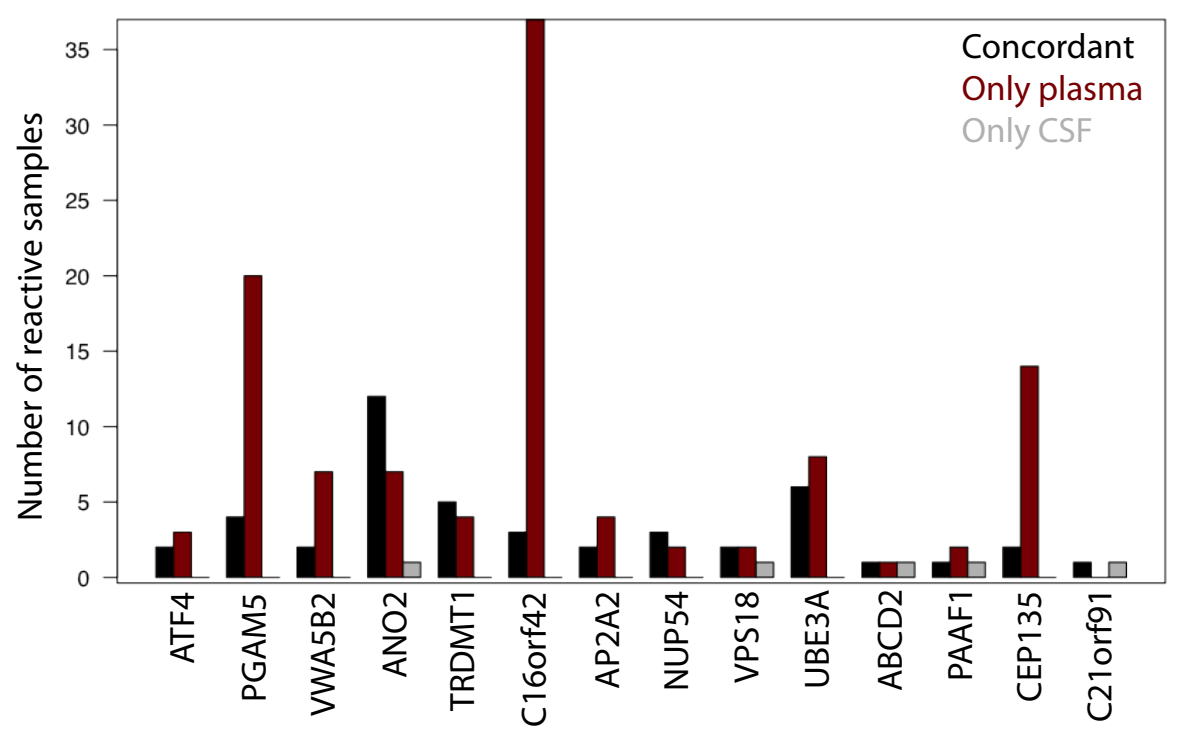

Figure 19: Paired CSF samples were analysed revealing concordant reactivity profiles for 14 of the 51 antigens. The absolute majority of reactivities found in CSF were also observed in plasma from the same patient.

independent sample material consisting of approximately 2200 MS patients and population controls. The preliminary results reveal ANO2 as the most interesting antigen, with reactivity in $14 \%$ of MS patients compared to only $2 \%$ of controls [Ayoglu et al, Submitted]. Interestingly, this was also the protein that was identified with the highest correlation of reactivity between plasma and CSF. Concordant results in the two sample materials imply that either systemic IgG can cross the blood brain barrier into the CNS, or that intrathecally produced IgG is absorbed into the blood circulation and are present at detectable levels using this technology.

\section{Paper V: Autoimmunity profiling of serum within narcolepsy}

The hypothesis that autoimmune mechanisms are the underlying cause of disease in narcolepsy is based on the strong genetic association of HLA alleles and the specific loss of hypocretin producing neurons. In this paper, we investigated reactivity of the IgG repertoire in serum of narcolepsy patients. We also compared reactivity in vaccine-associated disease, as reported after the vaccination campaigns against H1N1 influenza in 2009, to sporadic disease. Serum from 57 Finnish patients and controls were screened for reactivity against 11520 protein fragments using the planar microarray format. Antigens with higher reactivity in the narcolepsy group compared to controls or with differential reactivity be- 
tween vaccine-associated and sporadic disease were selected and subjected to verification analysis using the bead-based system. Initially, the same sample set was analysed but in a second stage an additional set of 152 plasma samples from a Swedish sample collection was used.

Similarly to the findings reported in Paper IV, a broad individual heterogeneity was observed among the samples analysed in the screening. After the first stage of verification, reactivity towards 14 protein fragments were reproducibly identified as differential between the sample groups. These included fragments with differential reactivity in comparison of all narcolepsy patients to the controls as well as between vaccine-associated and sporadic disease. Out of the 14 fragments, three were found with higher reactivity frequency also in the narcolepsy group of the Swedish samples compared to their corresponding controls. The three proteins were transmembrane protein 134 (TMEM134), cytosolic 5-nucelotidase 1A (NT5C1A) and methyltransferase-like protein 22 (METTL22). Although the narcolepsy group displayed higher reactivity in both cohorts, controls from the second sample set also indicated reactivity but with lower frequency (Figure 20).
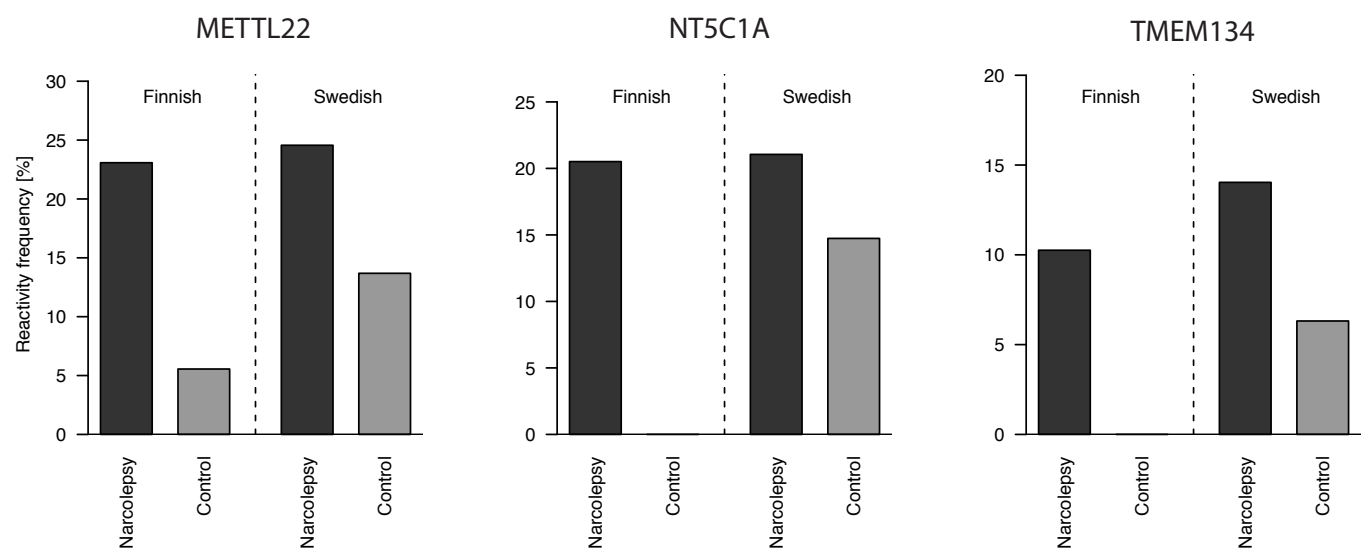

Figure 20: Higher reactivity was observed among narcolepsy patients compared to controls in both independent sample materials for three proteins, namely METTL22, NT5C1A and TMEM134.

To further characterise the epitopes of human antibodies towards the 14 proteins, one sample with high reactivity towards these was analysed on a high-density peptide array containing peptides representing all human proteins. Although this sample was reactive to five of the 14 protein fragments, it revealed reactivity towards peptides corresponding to only two of the proteins. This observation perhaps reflects the difference in protein representation between peptides composed of 12 amino acids compared to fragments approximately 10 times longer. It could also indicate that the antibodies detected recognised 
conformational rather than linear epitopes of these protein fragments.

For the fragments recognised to a higher extent by vaccine-associated patients, we computationally divided the fragments into 12-mer peptides and performed sequence comparisons to the H1N1 proteome. The analysis revealed several fragments with stretches of similar amino acid sequences as the viral proteins. The antigens identified as autoantibody targets in this study are to be further characterised using both peptides and full-length proteins in order to increase the understanding of reactivity towards these proteins and their potential role in narcolepsy.

\section{Conclusions and future perspectives}

This work is based on profiling of proteins and antibodies within neurological disorders through the use of microarray technologies. While working with these studies, a number of challenges appeared, including differences in sample composition, sample handling effects, transitions from single binder to dual binder assays and individual heterogeneity. Despite these, both protein and autoantibody profiles associated to disease were identified within MS, ALS and narcolepsy.

Microarray technologies allow for analysis of both samples and analytes in a high-throughput manner and such methods are thereby suitable for profiling studies aiming to discover disease related profiles. In Paper I-III, protein profiles associated to MS and ALS were found through analysis of both CSF and plasma. Although the differences between sample groups were statistically significant, variation within the groups were observed and an overlap of levels between groups seen for all proteins. Therefore, longitudinal studies following individuals over time would be of interest. Such studies could evaluate normal fluctuations in protein abundance. Furthermore, the relation to other individuals would in such analysis be of less importance as instead, deviations from individual baselines could be assessed. For the proteins reported in Paper I-II, analysis of a longitudinal cohort of MS patients is currently ongoing.

Individual variation was also observed in terms of autoimmune reactivity as reported in Paper IV and V. These studies as well as those reported by others describe extensive reactivity to human proteins, also in healthy controls, with a majority of antigens recognised by only one or a few individuals. It has become evident that antibodies with common reactivities among several individuals are rare and that disease related patterns are difficult to find. To further investigate the suggested autoantigens presented within MS and narcolepsy, it would be of interest to extend the analysis to also include additional diseases with and without neurological character. Furthermore, evaluation of the $\operatorname{IgG}$ repertoire of the general population in a broader sense could increase our current understanding of 
antibodies present in circulation even without symptoms of disease. It would also be of great interest to extend the analysis of antibodies in CSF and to further characterise the correlation of presence in blood and CSF.

Protocols for profiling of proteins and antibodies of both blood-based samples and CSF have paved the way for further analysis of the neuroproteome. Although there are proteins reported as related to neurological disorders, the amount of published work on large scale profiling studies is substantially lower than within other research areas, such as cancer. One reason might be the limited access to sample materials, especially tissue, but also proximal fluid. The invasive procedure of CSF collection is well appreciated and sample availability from healthy controls, and also patients, is limited. For this reason, profiling of plasma or serum can enable analysis of larger sample materials. To evaluate disease specificity of the findings described above as well as to discover novel signatures, an extensive effort on neuroproteomic profiling is currently being initiated. Antigens and antibodies derived from the Human Protein Atlas in combination with assay protocols established within the work of this thesis will be utilised for protein and autoantibody profiling within and between several neurological disorders. Besides MS, ALS and narcolepsy, plasma and CSF samples from patients with $\mathrm{AD}$ and $\mathrm{PD}$ will also be included. In addition, patients with muscular dystrophies, chronic mental illnesses and other forms of dementia will be analysed. As a starting point, the above presented proteins will also be complemented with those indicated as brain enriched based on the transcriptomic studies discussed. These proteins will be investigated in the complete set of samples representing all the above-mentioned diseases, in both plasma or serum and CSF to unravel the commonalities and specificities of disease associated protein profiles.

The work presented in this thesis provides a framework for protein and autoantibody profiling within neuroscience. Based on the knowledge and experience acquired, we will take affinity-based neuroproteomics to the next level and perform extensive profiling within and across several diseases. Hopefully our efforts will result in discovery of disease related profiles that ultimately can contribute to increased understanding, treatment and cure for neurological disorders. 


\section{Acknowledgements}

First of all, I would like to say how thankful I am to everyone who are willing to contribute to science by sample donation, even at times when life is tough. Without you, our research would not be possible. I also want to acknowledge ProNova for the financial support I have received during these years.

Tack Mathias för att du skapade proteinatlasen. Utan dina idéer och ditt outtröttliga engagemang tillsammans med den enorma insatsen från alla inblandade hade vi inte kunnat göra det vi gör. Jag är tacksam och glad över att få vara en del av något så unikt.

To all the fantastic people in the PAPP group: thank you so much for all your support and care. I am so happy to be around you every day.

Peter and Jochen, thank you for believing in me, giving me space to develop and for always keeping your doors open. You have created a unique working environment with amazing people who not only do great science but also truly care about each other. I am so proud and grateful to be a part of this. Peter, tack för allt stöd, all uppmuntran och alla möten då jag kommit nedslagen och gått med känslan av att vi är något spännande på spåren. Din entusiasm och energi smittar verkligen av sig. Det är imponerande att du kan ha ett sånt engagemang och intresse för alla våra projekt, trots att det vid det här laget börjar bli ganska många. Jochen, I really appreciate all our chats about project planning and that you always share new things you hear and see. Thanks for your support and encouragement when things have been tough and for challenging me to make me better at what I do. I have learnt so much from you.

Maja och Ulrika, ni är mina storasystrar på jobbet och att jag haft ert stöd hela vägen från början till slut har betytt så otroligt mycket för mig. Ulrika, du var en fantastisk handledare under exjobbet och jag tror att de där första dagarna i kylrummet gjorde mig till en bättre forskare. Tack för alla de gånger du ställt upp, tagit dig tid fast du varit upptagen och delat med dig av alla dina erfarenheter. Maja, jag är glad att jag haft någon att tillsammans kunnat vara skeptisk mot nya instrument med (och vi har ju haft rätt ibland, eller hur?). Tack för all pepp, insikten om att man kan slasklabba och för alla diskussioner om vad som egentligen försiggår på ytan på de där kulorna.

Burcu and Sanna, it has been so nice to work with you in the MS projects. Burcu, thank your for dragging me up in the ferry wheel that time in Göteborg. I still think about it whenever I have to get out of my comfort zone. Also, thank you for all your input on the subject of data analysis. Sanna, tack för alla gånger du påmint mig om att inte krångla till det i onödan och för alla diskussioner om normalisering och bias.

Mun-Gwan, I am so happy that you joined us and stopped me from getting lost in the 
deep, deep forrest of statistics. Maria, det är så roligt att samarbeta med dig. Tack för uppmuntrande ord när jag behövt det som bäst. Arash, tack för all hjälp med skript, sekvensjämförelser och samtal om autoimmunitet. Kimi, du var en fantastisk skrivbordsgranne, tack för alla gånger du fått mig att skratta när jag verkligen behövt tänka på något annat. Tack också för all hjälp i labbet och för att du har koll på det mesta man kan tänkas behöva veta. Claudia, thank you for all the times we discussed antibodies, mass spec and life in general. It is what it is, right? Ronald, du kan så mycket om så många saker, tack för att du delar med dig. Det har känts bra att haft en norrlänning att gadda ihop sig med ibland. Elin, tack för all praktisk hjälp i labbet och för att du ser till att vi alla kan ha roligt tillsammans utanför jobbet också. Din positiva inställning speglar sig i oss andra. Cecilia M, vi har det så bra i vårt hörn med blommor och allt, eller hur? Tack för all hjälp i labbet och för att du orkar lyssna på mina problem. Eni, du är en sådan fantastisk kollega. Tack för alla buffertar och beställningar, för att du tar hand om så mycket mer än vi förstår och för all indonesisk mat vi fått smaka. Maria-Jesus, thank you for caring, understanding and for all help on sandwich assay development. Björn, tack för allt du lärt mig om epitopmappning och peptider och för alla gånger du fått mig att tagga ner lite. Jag vill rikta ett stort tack till Ida, Lovisa och Cecilia $\mathbf{H}$ för ovärderlig hjälp med PrESTar och prover. Tack också till mina två exjobbare, Suzan och Atefeh, som jag fick möjligheten att handleda. Jag lärde mig mycket och hoppas att ni också gjorde det. To all other past and present members of the group; Jacob, Masato, Elisa, Philip, David, Fredrik, Frauke, Josefine, Julie, Anna G and Mårten, thank you for making this group what it is. I've had a great time working with you!

Jan and Nick, thank you for showing me the world of brain tissue. I have learnt a lot! I also want to say thanks to Jan, Evelina and Linn for introducing me to the world of RNA sequencing.

Tack till Tomas och Mohsen för det fantastiska MS-materialet som lagt grunden för så mycket av det jag gjort. Det är alltid roligt att diskutera och resonera tillsammans med er.

Magda, thanks for your kind hospitality during our visit. I have enjoyed our collaboration and hope we can continue working together.

Martin, Jonas, Kim och resten av gänget i Uppsala, tack för utbyte av erfarenheter angående provprep och korrelation mellan plattformar. Jag ser fram emot att få sätta igång med våra planerade aktiviteter.

Calle, tack för alla diskussioner om våra gemensamma och separata projekt, för assistans i labbet och inte minst utbytet av huserfarenheter. Johan, Anders, Hans och Emil; stort tack för ert engagemang och alla diskussioner. Även om dessa projekt inte hamnade 
i avhandlingen har de gett mig många erfarenheter jag tar med mig in i framtiden.

Helena och Elin, luncherna med er har verkligen varit välkomna avbrott mitt i allt labbande, analyserande och skrivande. Snart är det er tur, heja heja!

Tove, Filippa, Lisa, Hanna och Johan, det har varit så roligt att göra detta tillsammans med er hela vägen från början till slut. Åren har gått så fort och det är svårt att förstå att vi är färdiga nu. Tack för forskningsprat, uppmuntran, fikapauser, luncher och middagar. Tack också till Sara, Anna P, Joel, Magdalena och Emilie för allt roligt vi haft tillsammans.

Peter, Jochen, Ulrika, Maria, Nick, mamma, pappa och Jakob - thank you so much for great feedback during the process of thesis writing and Emma for valuable comments and the formal quality control.

Det finns förstås också många människor utanför jobbet som betyder mycket för mig. Tack till mina fantastiska vänner; Térèse, David, Therese, Stefan, Simon, Johan, Niklas, Elin, Mats och Josefin för alla galna upptåg och roliga minnen. Jag ska fortsätta försöka bota MS, jag lovar. Extra tack till Térèse, Therese och Annie för alla mysiga middagar, för att ni alltid bryr er och stöttar. Det har betytt så oerhört mycket. Annie, jag vet att du kan måla men dina tolkningar av nervceller översteg verkligen mina förväntningar. Tack för att du vågade och ville! Jenny, tack för allt stöd och engagemang trots att du haft det tufft på eget håll. Jag tror vi lärt oss mycket av varandra. Maria, tack för alla middagar och prat om jobbet, livet och allt annat. Emma, Emil, Marta och Peter, tack för att ni är ni och för att jag får vara en del av era liv.

Ett stort tack från hela mitt hjärta till familjerna Häggmark och Månberg. Tack för att ni alltid frågar hur det går och bryr er om mig. Mamma och pappa, vad jag än bestämt mig för att göra har ni stöttat mig. Tack för att jag fått gå min egen väg och för att ni alltid ställer upp. Elin, min underbara syster och bästa vän. Vi är så olika men ändå så lika. Du, Andreas, Tilde och Olivia påminner mig om vad som egentligen är viktigt i livet.

Jakob, ibland tror jag du känner mig bättre än jag gör själv. Jag är så glad att jag varje morgon får vakna och dela ännu en dag med dig. Tack för att du förstår mig utan att jag behöver säga något och att du finns där när jag behöver det. Det betyder allt. 


\section{Bibliography}

[1] Johannes Evangelista Purkinje. Neueste Untersuchungen aus der Nerven und Hirnanatomie . Bericht über die Versammlung deutscher Naturforscher und Ärzte, pages pp 177-80, September 1837.

[2] Ortwin Bock. Cajal, Golgi, Nansen, Schäfer and the Neuron Doctrine. Endeavour, 37(4):228-234, December 2013.

[3] Tim Green, Stephen F Heinemann, and JimF Gusella. Molecular Neurobiology and Genetics: Review Investigation of Neural Functionand Dysfunction. Neuron, pages 1-18, March 1998.

[4] Alex Bayés and Seth G N Grant. Neuroproteomics: understanding the molecular organization and complexity of the brain. Nature Reviews Neuroscience, 10(9):635-646, September 2009.

[5] Mithilesh Kumar Jha, Jae-Hong Kim, and Kyoungho Suk. Proteome of brain glia: The molecular basis of diverse glial phenotypes. PROTEOMICS, 14(4-5):378-398, October 2013.

[6] Chunzhang Yang, Shervin Rahimpour, Albert C H Yu, Russell R Lonser, and Zhengping Zhuang. Regulation and dysregulation of astrocyte activation and implications in tumor formation. Cellular and Molecular Life Sciences, 70(22):4201-4211, February 2013.

[7] Matthew R Hynd, Joanne M Lewohl, Heather L Scott, and Peter R Dodd. Biochemical and molecular studies using human autopsy brain tissue. Journal of Neurochemistry, 85(3):543-562, March 2003.

[8] Evelyne Maes, Valérie Broeckx, Inge Mertens, Xavier Sagaert, Hans Prenen, Bart Landuyt, and Liliane Schoofs. Analysis of the formalin-fixed paraffin-embedded tissue proteome: pitfalls, challenges, and future prospectives. Amino Acids, 45(2):205-218, April 2013.

[9] Hans Kretzschmar. Brain banking: opportunities, challenges and meaning for the future. Nature Reviews Neuroscience, 10(1):70-77, January 2009.

[10] Graeme I Murray. An overview of laser microdissection technologies. Acta Histochemica, 109(3):171-176, June 2007.

[11] Fengju Bai and Frank A Witzmann. Synaptosome Proteomics. In Subcellular Proteomics, pages 77-98. Springer Netherlands, Dordrecht, 2007.

[12] Leszek Herbowski. The Maze of the Cerebrospinal Fluid Discovery. Anatomy Research International, 2013(6765):1-8, 2013.

[13] Steven I Hajdu. A Note from History: Discovery of the Cerebrospinal Fluid. Annals of Clinical E3 Laboratory Science, 33(3):334-336, January 2003.

[14] F Deisenhammer, A Bartos, R Egg, N E Gilhus, G Giovannoni, S Rauer, and F Sellebjerg. Guidelines on routine cerebrospinal fluid analysis. Report from an EFNS task force. European Journal of Neurology, 13(9):913-922, September 2006 .

[15] Axel Regeniter, Jens Kuhle, Matthias Mehling, Helgard Möller, Ulrich Wurster, Heike Freidank, and Werner H Siede. A modern approach to CSF analysis: Pathophysiology, clinical application, proof of concept and laboratory reporting. Clinical Neurology and Neurosurgery, 111(4):313-318, May 2009. 
[16] Conrad E Johanson, John A Duncan, Petra M Klinge, Thomas Brinker, Edward G Stopa, and Gerald D Silverberg. Multiplicity of cerebrospinal fluid functions: New challenges in health and disease. Cerebrospinal Fluid Research, $5(1): 10,2008$.

[17] CHRISTER NILSSON, FREDDY STAHLBERG, CARSTEN THOMSEN, OLE HENRIKSEN, MARGARETE HERNING, and CHRISTER OWMAN. Circadian variation in human cerebrospinal fluid production measured by magnetic resonance imaging. Am J Physiol., 262(Jan):20-24, August 1992.

[18] Hansotto Reiber. Proteins in cerebrospinal fluid and blood: Barriers, CSF flow rate and source-related dynamics. Restorative Neurology and Neuroscience, 21:79-96, September 2003.

[19] Tomas Hökfelt, Christian Broberger, Zhi-Qing David Xu, Valeriy Sergeyev, Ruud Ubink, and Margarita Diez. Neuropeptides - an overview. Neuropharmacology, 39:1337-1356, December 2000.

[20] Andreas F Huhmer, Roger G Biringera, Heidi Amatob, Alfred N Fontehb, and Michael G Harringtonb. Protein analysis in human cerebrospinal fluid: Physiological aspects, current progress and future challenges. Disease Markers, 22:3-26, December 2006.

[21] Kapil G Kapoor, Steven E Katz, Deborah M Grzybowski, and Martin Lubow. Cerebrospinal fluid outflow: An evolving perspective. Brain Research Bulletin, 77(6):327-334, December 2008.

[22] Agamemnon Despopoulus and Stefan Silbernagl. Color Atlas of Physiology 5th 2003 Thieme. Georg Thieme Verlag, December 2005.

[23] C Kampf, A Mardinoglu, L Fagerberg, B M Hallstrom, K Edlund, E Lundberg, F Ponten, J Nielsen, and M Uhlen. The human liver-specific proteome defined by transcriptomics and antibody-based profiling. The FASEB Journal, 28(7):2901-2914, June 2014.

[24] N L Anderson. The Human Plasma Proteome: A Nonredundant List Developed by Combination of Four Separate Sources. Molecular \& Cellular Proteomics, 3(4):311-326, January 2004.

[25] Gilbert S Omenn, David J States, Marcin Adamski, Thomas W Blackwell, Rajasree Menon, Henning Hermjakob, Rolf Apweiler, Brian B Haab, Richard J Simpson, James S Eddes, Eugene A Kapp, Robert L Moritz, Daniel W Chan, Alex J Rai, Arie Admon, Ruedi Aebersold, Jimmy Eng, William S Hancock, Stanley A Hefta, Helmut Meyer, Young-Ki Paik, Jong Shin Yoo, Peipei Ping, Joel Pounds, Joshua Adkins, Xiaohong Qian, Rong Wang, Valerie Wasinger, Chi Yue Wu, Xiaohang Zhao, Rong Zeng, Alexander Archakov, Akira Tsugita, Ilan Beer, Akhilesh Pandey, Michael Pisano, Philip Andrews, Harald Tammen, David W Speicher, and Samir M Hanash. Overview of the HUPO Plasma Proteome Project: Results from the pilot phase with 35 collaborating laboratories and multiple analytical groups, generating a core dataset of 3020 proteins and a publicly-available database. PROTEOMICS, 5(13):3226-3245, August 2005.

[26] David J States, Gilbert S Omenn, Thomas W Blackwell, Damian Fermin, Jimmy Eng, David W Speicher, and Samir M Hanash. Challenges in deriving high-confidence protein identifications from data gathered by a HUPO plasma proteome collaborative study. Nature Biotechnology, 24(3):333-338, March 2006.

[27] Terry Farrah, Eric W Deutsch, Gilbert S Omenn, Zhi Sun, Julian D Watts, Tadashi Yamamoto, David Shteynberg, Micheleen M Harris, and Robert L Moritz. State of the Human Proteome in 2013 as Viewed through PeptideAtlas: Comparing the Kidney, Urine, and Plasma Proteomes for the Biology- and Disease-Driven Human Proteome Project. Journal of Proteome Research, 13(1):60-75, January 2014.

[28] Irena Dujmovic. Cerebrospinal Fluid and Blood Biomarkers of Neuroaxonal Damage in Multiple Sclerosis. Multiple Sclerosis International, 2011(6):1-18, 2011.

[29] Johanna Gaiottino, Niklas Norgren, Ruth Dobson, Joanne Topping, Ahuva Nissim, Andrea Malaspina, Jonathan P Bestwick, Andreas U Monsch, Axel Regeniter, Raija L Lindberg, Ludwig Kappos, David Leppert, Axel Petzold, Gavin Giovannoni, and Jens Kuhle. Increased Neurofilament Light Chain Blood Levels in Neurodegenerative Neurological Diseases. PLoS ONE, 8(9):e75091, September 2013.

[30] Jochen M Schwenk, Marcus Gry, Rebecca Rimini, Mathias Uhlén, and Peter Nilsson. Antibody Suspension Bead Arrays within Serum Proteomics. Journal of Proteome Research, 7(8):3168-3179, August 2008.

[31] Irene Weibrecht, Karl-Johan Leuchowius, Carl-Magnus Clausson, Tim Conze, Malin Jarvius, W Mathias Howell, Masood Kamali-Moghaddam, and Ola Söderberg. Proximity ligation assays: a recent addition to the proteomics toolbox. Expert Review of Proteomics, 7(3):401-409, June 2010. 
[32] Michael J Hawrylycz, Ed S Lein, Angela L Guillozet-Bongaarts, Elaine H Shen, Lydia Ng, Jeremy A Miller, Louie N van de Lagemaat, Kimberly A Smith, Amanda Ebbert, Zackery L Riley, Chris Abajian, Christian F Beckmann, Amy Bernard, Darren Bertagnolli, Andrew F Boe, Preston M Cartagena, M Mallar Chakravarty, Mike Chapin, Jimmy Chong, Rachel A Dalley, Barry David Daly, Chinh Dang, Suvro Datta, Nick Dee, Tim A Dolbeare, Vance Faber, David Feng, David R Fowler, Jeff Goldy, Benjamin W Gregor, Zeb Haradon, David R Haynor, John G Hohmann, Steve Horvath, Robert E Howard, Andreas Jeromin, Jayson M Jochim, Marty Kinnunen, Christopher Lau, Evan T Lazarz, Changkyu Lee, Tracy A Lemon, Ling Li, Yang Li, John A Morris, Caroline C Overly, Patrick D Parker, Sheana E Parry, Melissa Reding, Joshua J Royall, Jay Schulkin, Pedro Adolfo Sequeira, Clifford R Slaughterbeck, Simon C Smith, Andy J Sodt, Susan M Sunkin, Beryl E Swanson, Marquis P Vawter, Derric Williams, Paul Wohnoutka, H Ronald Zielke, Daniel H Geschwind, Patrick R Hof, Stephen M Smith, Christof Koch, Seth G N Grant, and Allan R Jones. An anatomically comprehensive atlas of the adult human brain transcriptome. Nature, 489(7416):391-399, April 2013.

[33] L Fagerberg, B M Hallstrom, P Oksvold, C Kampf, D Djureinovic, J Odeberg, M Habuka, S Tahmasebpoor, A Danielsson, K Edlund, A Asplund, E Sjostedt, E Lundberg, C A K Szigyarto, M Skogs, J O Takanen, H Berling, H Tegel, J Mulder, P Nilsson, J M Schwenk, C Lindskog, F Danielsson, A Mardinoglu, A Sivertsson, K von Feilitzen, M Forsberg, M Zwahlen, I Olsson, S Navani, M Huss, J Nielsen, F Ponten, and M Uhlen. Analysis of the Human Tissue-specific Expression by Genome-wide Integration of Transcriptomics and Antibody-based Proteomics. Molecular 83 Cellular Proteomics, 13(2):397-406, January 2014.

[34] Daniel Ramsköld, Eric T Wang, Christopher B Burge, and Rickard Sandberg. An Abundance of Ubiquitously Expressed Genes Revealed by Tissue Transcriptome Sequence Data. PLoS Computational Biology, 5(12):e1000598, December 2009 .

[35] Saad Haider and Ranadip Pal. Integrated Analysis of Transcriptomic and Proteomic Data. Current Genomics, 14:91110, February 2013.

[36] Emma Lundberg, Linn Fagerberg, Daniel Klevebring, Ivan Matic, Tamar Geiger, Juergen Cox, Cajsa Auml lgen auml s, Joakim Lundeberg, Matthias Mann, and Mathias Uhlén. Defining the transcriptome and proteome in three functionally different human cell lines. Molecular Systems Biology, 6:1-9, December 2010.

[37] WPK Lou, A Baser, and S Klußmann. In vivo Interrogation of Central Nervous System Translatome by Polyribosome Fractionation. JoVE (Journal of ..., 2014.

[38] A Kratz, P Beguin, M Kaneko, T Chimura, A M Suzuki, A Matsunaga, S Kato, N Bertin, T Lassmann, R Vigot, $\mathrm{P}$ Carninci, C Plessy, and T Launey. Digital expression profiling of the compartmentalized translatome of Purkinje neurons. Genome Research, 24(8):1396-1410, August 2014.

[39] Min-Sik Kim, Sneha M Pinto, Derese Getnet, Raja Sekhar Nirujogi, Srikanth S Manda, Raghothama Chaerkady, Anil K Madugundu, Dhanashree S Kelkar, Ruth Isserlin, Shobhit Jain, Joji K Thomas, Babylakshmi Muthusamy, Pamela LealRojas, Praveen Kumar, Nandini A Sahasrabuddhe, Lavanya Balakrishnan, Jayshree Advani, Bijesh George, Santosh Renuse, Lakshmi Dhevi N Selvan, Arun H Patil, Vishalakshi Nanjappa, Aneesha Radhakrishnan, Samarjeet Prasad, Tejaswini Subbannayya, Rajesh Raju, Manish Kumar, Sreelakshmi K Sreenivasamurthy, Arivusudar Marimuthu, Gajanan J Sathe, Sandip Chavan, Keshava K Datta, Yashwanth Subbannayya, Apeksha Sahu, Soujanya D Yelamanchi, Savita Jayaram, Pavithra Rajagopalan, Jyoti Sharma, Krishna R Murthy, Nazia Syed, Renu Goel, Aafaque A Khan, Sartaj Ahmad, Gourav Dey, Keshav Mudgal, Aditi Chatterjee, Tai-Chung Huang, Jun Zhong, Xinyan Wu, Patrick G Shaw, Donald Freed, Muhammad S Zahari, Kanchan K Mukherjee, Subramanian Shankar, Anita Mahadevan, Henry Lam, Christopher J Mitchell, Susarla Krishna Shankar, Parthasarathy Satishchandra, John T Schroeder, Ravi Sirdeshmukh, Anirban Maitra, Steven D Leach, Charles G Drake, Marc K Halushka, T S Keshava Prasad, Ralph H Hruban, Candace L Kerr, Gary D Bader, Christine A Iacobuzio-Donahue, Harsha Gowda, and Akhilesh Pandey. A draft map of the human proteome. Nature, 509(7502):575-581, May 2014.

[40] Mathias Wilhelm, Judith Schlegl, Hannes Hahne, Amin Moghaddas Gholami, Marcus Lieberenz, Mikhail M Savitski, Emanuel Ziegler, Lars Butzmann, Siegfried Gessulat, Harald Marx, Toby Mathieson, Simone Lemeer, Karsten Schnatbaum, Ulf Reimer, Holger Wenschuh, Martin Mollenhauer, Julia Slotta-Huspenina, Joos-Hendrik Boese, Marcus Bantscheff, Anja Gerstmair, Franz Faerber, and Bernhard Kuster. Mass-spectrometry-based draft of the human proteome. Nature, 509(7502):582-587, April 2015.

[41] Daniel Martins-de Souza, Paulo C Carvalho, Andrea Schmitt, Magno Junqueira, Fábio C S Nogueira, Christoph W Turck, and Gilberto B Domont. Deciphering the Human Brain Proteome: Characterization of the Anterior Temporal Lobe and Corpus Callosum As Part of the Chromosome 15-centric Human Proteome Project. Journal of Proteome Research, 13(1):147-157, January 2014. 
[42] Daniel Martins-de Souza, Giuseppina Maccarrone, Stefan Reckow, Peter Falkai, Andrea Schmitt, and Christoph W Turck. Shotgun mass spectrometry analysis of the human thalamus proteome. Journal of Separation Science, 32(8):1231-1236, April 2009.

[43] Daniel Martins-de Souza, Paul C Guest, Francesca L Guest, Corinna Bauder, Hassan Rahmoune, Sandra Pietsch, Sigrum Roeber, Hans Kretzschmar, David Mann, Atik Baborie, and Sabine Bahn. Characterization of the human primary visual cortex and cerebellum proteomes using shotgun mass spectrometry-data-independent analyses. PROTEOMICS, 12(3):500-504, January 2012.

[44] Daniel Martins-de Souza, Paul C Guest, Hannah Steeb, Sandra Pietsch, Hassan Rahmoune, Laura W Harris, and Sabine Bahn. Characterizing the proteome of the human dorsolateral prefrontal cortex by shotgun mass spectrometry. PROTEOMICS, 11(11):2347-2353, May 2011.

[45] Sheng Pan, Min Shi, Jinghua Jin, Roger L Albin, Andy Lieberman, Marla Gearing, Biaoyang Lin, Catherine Pan, Xiaowei Yan, Daniel T Kashima, and Jing Zhang. Proteomics Identification of Proteins in Human Cortex Using Multidimensional Separations and MALDI Tandem Mass Spectrometer*. Molecular \& Cellular Proteomics, 6(10):18181823, September 2007.

[46] Joaquín Fernández-Irigoyen, Fernando J Corrales, and Enrique Santamaría. Proteomic atlas of the human olfactory bulb. Journal of Proteomics, 75(13):4005-4016, July 2012.

[47] W Michael Caudle, Sheng Pan, Min Shi, Thomas Quinn, Jake Hoekstra, Richard P Beyer, Thomas J Montine, and Jing Zhang. Proteomic identification of proteins in the human brain: Towards a more comprehensive understanding of neurodegenerative disease. PROTEOMICS - Clinical Applications, 2(10-11):1484-1497, October 2008.

[48] Lujian Liao, Daniel B McClatchy, and John R Yates. Shotgun Proteomics in Neuroscience. Neuron, 63(1):12-26, July 2009.

[49] Young Mok Park, Jin Young Kim, Kyung-Hoon Kwon, Sang Kwang Lee, Young Hye Kim, Se-Young Kim, Gun Wook Park, Jeong Hwa Lee, Bonghee Lee, and Jong Shin Yoo. Profiling human brain proteome by multi-dimensional separations coupled with MS. PROTEOMICS, 6(18):4978-4986, September 2006.

[50] Sravani Musunuri, Ganna Shevchenko, and Jonas Bergquist. Neuroproteomic profiling of human brain tissue using multidimensional separation techniques and selective enrichment of membrane proteins. ELECTROPHORESIS, 33(24):3779-3785, December 2012.

[51] Sarah Plum, Simone Steinbach, Laura Abel, Katrin Marcus, Stefan Helling, and Caroline May. Proteomics in neurodegenerative diseases: Methods for obtaining a closer look at the neuronal proteome. PROTEOMICS - Clinical Applications, pages n/a-n/a, September 2014.

[52] Mithilesh Kumar Jha, Minchul Seo, Jong-Heon Kim, Byung-Gyu Kim, Je-Yoel Cho, and Kyoungho Suk. Biochimica et Biophysica Acta. BBA - Proteins and Proteomics, 1834(11):2418-2428, November 2013.

[53] Elise Aasebø, Jill Anette Opsahl, Yngvild Bjørlykke, Kjell-Morten Myhr, Ann Cathrine Kroksveen, and Frode S Berven. Effects of Blood Contamination and the Rostro-Caudal Gradient on the Human Cerebrospinal Fluid Proteome. PLoS ONE, 9(3):e90429, March 2014.

[54] Jing Zhang, David R Goodlett, Elaine R Peskind, Joseph F Quinn, Yong Zhou, Qin Wang, Catherine Pan, Eugene Yi, Jimmy Eng, Ruedi H Aebersold, and Thomas J Montine. Quantitative proteomic analysis of age-related changes in human cerebrospinal fluid. Neurobiology of Aging, 26(2):207-227, February 2005.

[55] Sheng Pan, David Zhu, Joseph F Quinn, Elaine R Peskind, Thomas J Montine, Biaoyang Lin, David R Goodlett, Greg Taylor, Jimmy Eng, and Jing Zhang. A combined dataset of human cerebrospinal fluid proteins identified by multi-dimensional chromatography and tandem mass spectrometry. PROTEOMICS, 7(3):469-473, February 2007.

[56] Alexandre Zougman, Bartosz Pilch, Alexandre Podtelejnikov, Michael Kiehntopf, Claudia Schnabel, Chanchal Kumar, and Matthias Mann. Integrated Analysis of the Cerebrospinal Fluid Peptidome and Proteome. Journal of Proteome Research, 7(1):386-399, January 2008.

[57] Steven E Schutzer, Tao Liu, Benjamin H Natelson, Thomas E Angel, Athena A Schepmoes, Samuel O Purvine, Kim K Hixson, Mary S Lipton, David G Camp, Patricia K Coyle, Richard D Smith, and Jonas Bergquist. Establishing the Proteome of Normal Human Cerebrospinal Fluid. PLoS ONE, 5(6):e10980, June 2010. 
[58] Astrid Guldbrandsen, Heidrun Vethe, Yehia Farag, Eystein Oveland, Hilde Garberg, Magnus Berle, Kjell-Morten Myhr, Jill A Opsahl, Harald Barsnes, and Frode S Berven. In-depth characterization of the cerebrospinal fluid proteome displayed through the CSF Proteome Resource (CSF-PR). Molecular ES Cellular Proteomics, pages 1-40, July 2014.

[59] Hansotto Reiber. Dynamics of brain-derived proteins in cerebrospinal fluid. Clinica Chimica Acta, 310:173-186, August 2001.

[60] Sebastian Brandner, Christian Thaler, Piotr Lewczuk, Natalia Lelental, Michael Buchfelder, and Andrea Kleindienst. Neuroprotein Dynamics in the Cerebrospinal Fluid: Intraindividual Concomitant Ventricular and Lumbar Measurements. European Neurology, 70(3-4):189-194, 2013.

[61] D Hirtz, D J Thurman, K Gwinn-Hardy, M Mohamed, A R Chaudhuri, and R Zalutsky. How common are the "common" neurologic disorders? Neurobiology of Aging, 68:326-337, January 2007.

[62] Alastair Compston and Alasdair Coles. Multiple sclerosis. The Lancet, 372(9648):1502-1517, 2008.

[63] W Ian McDonald, Alistair Compston, Gilles Edan, Donald Goodkin, Hans-Peter Hartung, Fred D Lublin, Henry F McFarland, Donald W Paty, Chris H Polman, Stephen C Reingold, Magnhild Sandberg-Wollheim, William Sibley, Alan Thompson, Stanley van den Noort, Brian Y Weinshenker, and Jerry S Wolinsky. Recommended Diagnostic Criteria for Multiple Sclerosis: Guidelines from the International Panel on the Diagnosis of Multiple Sclerosis. Annals of Neurology, 50:121-127, June 2001.

[64] Hans Link and Yu-Min Huang. Oligoclonal bands in multiple sclerosis cerebrospinal fluid: An update on methodology and clinical usefulness. Journal of Neuroimmunology, 180(1-2):17-28, November 2006.

[65] Alexandre S Fortini, Elizabeth L Sanders, Brian G Weinshenker, and Jerry A Katzmann. Cerebrospinal Fluid Oligoclonal Bands in the Diagnosis of Multiple Sclerosis Isoelectric Focusing With IgG Immunoblotting Compared With High-Resolution Agarose Gel Electrophoresis and Cerebrospinal Fluid IgG Index. American Journal of Clinical Pathology, 120(5):672-675, November 2003.

[66] D A Compston, J R Batchelor, and W I McDonald. B-lymphocyte alloantigens associated with multiple sclerosis. The Lancet, 11(2):1261-1265, July 1976.

[67] Christina M Lill. Recent advances and future challenges in the genetics of multiple sclerosis. pages 1-4, July 2014.

[68] A Ascherio. Environmental factors in multiple sclerosis. Expert Rev Neurother., 13:3-9.

[69] D Jons, P Sundström, and O Andersen. Targeting Epstein-Barr virus infection as an intervention against multiple sclerosis. Acta Neurologica Scandinavica, pages n/a-n/a, September 2014.

[70] Francesca Odoardi, Christopher Sie, Kristina Streyl, Vijay K Ulaganathan, Christian Schläger, Dmitri Lodygin, Klaus Heckelsmiller, Wilfried Nietfeld, Joachim Ellwart, Wolfgang E F Klinkert, Claudio Lottaz, Mikhail Nosov, Volker Brinkmann, Rainer Spang, Hans Lehrach, Martin Vingron, Hartmut Wekerle, Cassandra Flügel-Koch, and Alexander Flügel. T cells become licensed in the lung to enter the central nervous system. Nature, 488(7413):675-679, August 2012 .

[71] A K Hedstrom, E Sundqvist, M Baarnhielm, N Nordin, J Hillert, I Kockum, T Olsson, and L Alfredsson. Smoking and two human leukocyte antigen genes interact to increase the risk for multiple sclerosis. Brain, 134(3):653-664, February 2011.

[72] Alessandro S Farias, Fernando Pradella, Andrea Schmitt, Leonilda M B Santos, and Daniel Martins-de Souza. Ten years of proteomics in multiple sclerosis. PROTEOMICS, 14(4-5):467-480, March 2014.

[73] Jan Ottervald, Bo Franzén, Kerstin Nilsson, Lars I Andersson, Mohsen Khademi, Bodil Eriksson, Sven Kjellström, György Marko-Varga, Ákos Végvári, Robert A Harris, Thomas Laurell, Tasso Miliotis, Darius Matusevicius, Hugh Salter, Mats Ferm, and Tomas Olsson. Multiple sclerosis: Identification and clinical evaluation of novel CSF biomarkers. Journal of Proteomics, 73(6):1117-1132, April 2010.

[74] Marcel P Stoop, Lennard J Dekker, Mark K Titulaer, Peter C Burgers, Peter A E Sillevis Smitt, Theo M Luider, and Rogier Q Hintzen. Multiple sclerosis-related proteins identified in cerebrospinal fluid by advanced mass spectrometry. PROTEOMICS, 8(8):1576-1585, April 2008. 
[75] A C Kroksveen, A Guldbrandsen, C Vedeler, K M Myhr, J A Opsahl, and F S Berven. Cerebrospinal fluid proteome comparison between multiple sclerosis patients and controls. Acta Neurologica Scandinavica, 126:90-96, December 2012.

[76] M Comabella, M Fernandez, R Martin, S Rivera-Vallve, E Borras, C Chiva, E Julia, A Rovira, E Canto, J C AlvarezCermeno, L M Villar, M Tintore, and X Montalban. Cerebrospinal fluid chitinase 3-like 1 levels are associated with conversion to multiple sclerosis. Brain, 133(4):1082-1093, April 2010.

[77] Manuel Comabella and Prof Xavier Montalban MD. Body fluid biomarkers in multiple sclerosis. The Lancet Neurology, 13(1):113-126, December 2013.

[78] Judith Fraussen, Nele Claes, Laura de Bock, and Veerle Somers. Autoimmunity Reviews. Autoimmunity Reviews, 13(11):1126-1137, November 2014.

[79] A A Belogurov, I N Kurkova, A Friboulet, D Thomas, V K Misikov, M Y Zakharova, S V Suchkov, S V Kotov, A I Alehin, B Avalle, E A Souslova, H C Morse, A G Gabibov, and N A Ponomarenko. Recognition and Degradation of Myelin Basic Protein Peptides by Serum Autoantibodies: Novel Biomarker for Multiple Sclerosis. The Journal of Immunology, 180(2):1258-1267, January 2008.

[80] Rajneesh Srivastava, Muhammad Aslam, Sudhakar Reddy Kalluri, Lucas Schirmer, Dorothea Buck, Björn Tackenberg, Veit Rothhammer, Andrew Chan, Ralf Gold, Achim Berthele, Jeffrey L Bennett, Thomas Korn, and Bernhard Hemmer. Potassium Channel KIR4.1 as an Immune Target in Multiple Sclerosis. New England Journal of Medicine, 367(2):115123, July 2012.

[81] E Nerrant, C Salsac, M Charif, X Ayrignac, C Carra-Dalliere, G Castelnovo, R Goulabchand, J Tisseyre, C Raoul, J F Eliaou, P Labauge, and T Vincent. Lack of confirmation of anti-inward rectifying potassium channel 4.1 antibodies as reliable markers of multiple sclerosis. Multiple Sclerosis Journal, April 2014.

[82] Veerle Somers, Cindy Govarts, Klaartje Somers, Raymond Hupperts, Rob Medaer, and Piet Stinissen. Autoantibody Profiling in Multiple Sclerosis Reveals Novel Antigenic Candidates. The Journal of Immunology, 180:3957-3963, February 2008.

[83] Jennifer L Kanter, Sirisha Narayana, Peggy P Ho, Ingrid Catz, Kenneth G Warren, Raymond A Sobel, Lawrence Steinman, and William H Robinson. Lipid microarrays identify key mediators of autoimmune brain inflammation. Nature Medicine, 12(1):138-143, December 2005.

[84] Francisco J Quintana, Mauricio F Farez, Vissia Viglietta, Antonio H Iglesias, Yifat Merbl, Guillermo Izquierdo, Miguel Lucas, Alexandre S Basso, Samia J Khoury, Claudia F Lucchinetti, Irun R Cohen, and Howard L Weiner. Antigen microarrays identify unique serumautoantibody signatures in clinical and pathologicsubtypes of multiple sclerosis. PNAS, 105(48):18889-18894, November 2008.

[85] Natascha Helena Beyer, Angelika Lueking, Axel Kowald, Jette Lautrup Frederiksen, and Niels H H Heegaard. Journal of Neuroimmunology. Journal of Neuroimmunology, 242(1-2):26-32, January 2012.

[86] A G Gabibov, A A Belogurov, Y A Lomakin, M Y Zakharova, M E Avakyan, V V Dubrovskaya, I V Smirnov, A S Ivanov, A A Molnar, V E Gurtsevitch, S V Diduk, K V Smirnova, B Avalle, S N Sharanova, A Tramontano, A Friboulet, A N Boyko, N A Ponomarenko, and N V Tikunova. Combinatorial antibody library from multiple sclerosis patients reveals antibodies that cross-react with myelin basic protein and EBV antigen. The FASEB Journal, 25(12):4211-4221, November 2011.

[87] L Hughes. Cross-reactivity between related sequences found in Acinetobacter sp., Pseudomonas aeruginosa, myelin basic protein and myelin oligodendrocyte glycoprotein in multiple sclerosis. Journal of Neuroimmunology, 144(1-2):105-115, November 2003.

[88] L E Lucca, S Desbois, A Ramadan, A Ben-Nun, M Eisenstein, N Carrie, J C Guery, A Sette, P Nguyen, T L Geiger, L T Mars, and R S Liblau. Bispecificity for Myelin and Neuronal Self-Antigens Is a Common Feature of CD4 T Cells in C57BL/6 Mice. The Journal of Immunology, 193(7):3267-3277, September 2014.

[89] D Baumer, K Talbot, and M R Turner. Advances in motor neurone disease. Journal of the Royal Society of Medicine, 107(1):14-21, January 2014.

[90] Ammar Al-Chalabi and Orla Hardiman. The epidemiology of ALS: a conspiracy of genes, environment and time. Nature Reviews Neurology, 9(11):617-628, October 2013. 
[91] A Chio, A Calvo, C Moglia, L Mazzini, G Mora, and PARALS study group. Phenotypic heterogeneity of amyotrophic lateral sclerosis: a population based study. Journal of Neurology, Neurosurgery \& Psychiatry, 82(7):740-746, June 2011.

[92] Benjamin Rix Brooks, Robert G Miller, Michael Swash, and Theodore L Munsat. El Escorial revisited: Revised criteria for the diagnosis of amyotrophic lateral sclerosis. ALS and other motor neuron disorders, 1:293-299, March 2000.

[93] Mamede de Carvalho, Reinhard Dengler, Andrew Eisen, John D England, Ryuji Kaji, Jun Kimura, Kerry Mills, Hiroshi Mitsumoto, Hiroyuki Nodera, Jeremy Shefner, and Michael Swash. Electrodiagnostic criteria for diagnosis of ALS. Clinical Neurophysiology, 119(3):497-503, March 2008.

[94] Lokesh C Wijesekera and P Nigel Leigh. Amyotrophic lateral sclerosis. Orphanet Journal of Rare Diseases, 4(1):3, 2009 .

[95] Martin R Turner, Robert Bowser, Lucie Bruijn, Luc Dupuis, Albert Ludolph, Michael McGrath, Giovanni Manfredi, Nicholas Maragakis, Robert G Miller, Seth L Pullman, Seward B Rutkove, Pamela J Shaw, Jeremy Shefner, and Kenneth H Fischbeck. Mechanisms, models and biomarkers in amyotrophic lateral sclerosis. Amyotrophic Lateral Sclerosis and Frontotemporal Degeneration, 14(S1):19-32, May 2013.

[96] Stefan Lehnert, Julia Costa, Mamede de Carvalho, Janine Kirby, Magdalena Kuźma-Kozakiewicz, Claudia Morelli, Wim Robberecht, Pamela Shaw, Vincenzo Silani, Petra Steinacker, Hayrettin Tumani, Philip Van Damme, Albert Ludolph, and Markus Otto. Multicentre quality control evaluation of different biomarker candidates for amyotrophic lateral sclerosis. Amyotrophic Lateral Sclerosis and Frontotemporal Degeneration, 15(5-6):344-350, September 2014.

[97] Kevin Boylan, Cui Yang, Julia Crook, Karen Overstreet, Michael Heckman, Yong Wang, David Borchelt, and Gerry Shaw. Immunoreactivity of the phosphorylated axonal neurofilament $\mathrm{H}$ subunit (pNF-H) in blood of ALS model rodents and ALS patients: evaluation of blood pNF-H as a potential ALS biomarker. Journal of Neurochemistry, 111(5):1182-1191, December 2009.

[98] Takashi Kasai, Takahiko Tokuda, Noriko Ishigami, Hiroshi Sasayama, Penelope Foulds, Douglas J Mitchell, David M A Mann, David Allsop, and Masanori Nakagawa. Increased TDP-43 protein in cerebrospinal fluid of patients with amyotrophic lateral sclerosis. Acta Neuropathologica, 117(1):55-62, November 2008.

[99] Esther Verstraete, H Bea Kuiperij, Marka M van Blitterswijk, Jan H Veldink, H Jurgen Schelhaas, Leonard H van den Berg, and Marcel M Verbeek. TDP-43 plasma levels are higher in amyotrophic lateral sclerosis. Amyotrophic Lateral Sclerosis, 13(5):446-451, September 2012.

[100] Thomas Krüger, Janin Lautenschläger, Julian Grosskreutz, and Heidrun Rhode. Proteome analysis of body fluids for amyotrophic lateral sclerosis biomarker discovery. PROTEOMICS - Clinical Applications, 7(1-2):123-135, January 2013.

[101] Srikanth Ranganathan, Eric Williams, Philip Ganchev, Vanathi Gopalakrishnan, David Lacomis, Leo Urbinelli, Kristyn Newhall, Merit E Cudkowicz, Robert H Brown, Jr., and Robert Bowser. Proteomic profiling of cerebrospinal fluid identifies biomarkers for amyotrophic lateral sclerosis. Journal of Neurochemistry, 95(5):1461-1471, September 2005.

[102] G M Pasinetti, L H Ungar, D J Lange, S Yemul, H Deng, X Yuan, R H Brown, M E Cudkowicz, K Newhall, E Peskind, MD S Marcus, and L Ho. Identification of potential CSF biomarkers in ALS. Neurobiology of Aging, 66:1218-1222, March 2006.

[103] Johannes Brettschneider, Vera Lehmensiek, Helga Mogel, Martin Pfeifle, Johannes Dorst, Corinna Hendrich, Albert C Ludolph, and Hayrettin Tumani. Proteome analysis reveals candidate markers of disease progression in amyotrophic lateral sclerosis (ALS). Neuroscience Letters, 468(1):23-27, January 2010.

[104] R M Mitchell, BS W M Freeman, W T Randazzo, H E Stephens, J L Beard, Z Simmons, and J R Connor. A CSF biomarker panel for identification of patients with amyotrophic lateral sclerosis. pages 1-8, December 2008.

[105] Stanley H Appel, R Glenn Smith, Jozsef I Engelhardt, and Enrico Stefani. Evidence for autoimmunity in amyotrophic lateral sclerosis. Journal of the Neurological Sciences, 118:169-174, November 1993.

[106] L Fialová, J Švarcová, A Bartos, P Ridzoň, I Malbohan, O Keller, and R Rusina. Cerebrospinal fluid and serum antibodies against neurofilaments in patients with amyotrophic lateral sclerosis. European Journal of Neurology, 17(4):562-566, April 2010. 
[107] John S Tzartos, Paraskevi Zisimopoulou, Michael Rentzos, Nikos Karandreas, Vasiliki Zouvelou, Panagiota Evangelakou, Anastasios Tsonis, Thomas Thomaidis, Giuseppe Lauria, Francesca Andreetta, Renato Mantegazza, and Socrates J Tzartos. LRP4 antibodies in serum and CSF from amyotrophic lateral sclerosis patients. Annals of Clinical and Translational Neurology, 1(2):80-87, December 2013.

[108] Caroline May, Eckhard Nordhoff, Swaantje Casjens, Michael Turewicz, Martin Eisenacher, Ralf Gold, Thomas Brüning, Beate Pesch, Christian Stephan, Dirk Woitalla, Botond Penke, Tamás Janáky, Dezső Virók, László Siklós, Jozsef I Engelhardt, and Helmut E Meyer. Highly Immunoreactive IgG Antibodies Directed against a Set of Twenty Human Proteins in the Sera of Patients with Amyotrophic Lateral Sclerosis Identified by Protein Array. PLoS ONE, 9(2):e89596, February 2014.

[109] Birgitte Rahbek Kornum, Juliette Faraco, and Emmanuel Mignot. Narcolepsy with hypocretin/orexin deficiency, infections and autoimmunity of the brain. Current Opinion in Neurobiology, 21(6):897-903, December 2011.

[110] Swarup Kumar and HaritHa Sagili. Etiopathogenesis and Neurobiology of Narcolepsy: A Review. JOURNAL OF CLINICAL AND DIAGNOSTIC RESEARCH, 8(2):190-195, 2014.

[111] Läkemedelsverket. Occurrence of narcolepsy with cataplexy among children and adolescents in relation to the H1N1 pandemic and Pandemrix vaccinations. Results of a case inventory study by the MPA in Sweden during 2009-2010. pages 1-20, June 2011.

[112] Hanna Nohynek, Jukka Jokinen, Markku Partinen, Outi Vaarala, Turkka Kirjavainen, Jonas Sundman, Sari-Leena Himanen, Christer Hublin, Ilkka Julkunen, Päivi Olsén, Outi Saarenpää-Heikkilä, and Terhi Kilpi. AS03 Adjuvanted AH1N1 Vaccine Associated with an Abrupt Increase in the Incidence of Childhood Narcolepsy in Finland. PLoS ONE, 7(3):e33536, March 2012.

[113] D O Flanagan, A S Barret, M Foley, S Cotter, C Bonner, C Crowe, B Lynch, B Sweeney, H Johnson, B McCoy, and E Purcell. Investigation of an association between onset of narcolepsy and vaccination with pandemic influenza vaccine, Ireland April 2009-December 2010. Euro Surveillance, 19(17), May 2014.

[114] Fabio Pizza, Hanna Peltola, Tomi Sarkanen, Keivan K Moghadam, Giuseppe Plazzi, and Markku Partinen. Childhood narcolepsy with cataplexy: comparison between post-H1N1 vaccination and sporadic cases. Sleep Medicine, 15(2):262265, February 2014.

[115] Carlo Perricone, Serena Colafrancesco, Roei D Mazor, Alessandra Soriano, Nancy Agmon-Levin, and Yehuda Shoenfeld. Journal of Autoimmunity. Journal of Autoimmunity, 47(C):1-16, December 2013.

[116] Seung-Chul Hong, Ling Lin, Jong-Hyun Jeong, Yoon-Kyung Shin, Jin-Hee Han, Ji-Hyun Lee, Sung-Pil Lee, Jing Zhang, Mali Einen, and Emmanuel Mignot. A Study of the Diagnostic Utility of HLA Typing, CSF Hypocretin-1 Measurements,and MSLT Testing for the Diagnosis of Narcolepsy in 163 Korean Patients WithUnexplained Excessive Daytime Sleepiness. Sleep, 29(11):1429-1438, November 2006.

[117] MASAKI NAKAMURA, TAKASHI KANBAYASHI, TATSUKI SUGIURA, and Yuichi Inoue. Relationship between clinical characteristics of narcolepsy and CSF orexin-A levels. Journal of Sleep Research, 20(1pt1):45-49, February 2011.

[118] Yves Dauvilliers, Isabelle Jaussent, Michel Lecendreux, Sabine Scholz, Sophie Bayard, Jean Paul Cristol, Hubert Blain, and Anne-Marie Dupuy. Cerebrospinal fluid and serum cytokine profiles in narcolepsy with cataplexy: A case-control study. Brain Behavior and Immunity, 37(C):260-266, March 2014.

[119] P Bergman, C Adori, S Vas, Y Kai-Larsen, T Sarkanen, A Cederlund, B Agerberth, I Julkunen, B Horvath, D Kostyalik, L Kalmar, G Bagdy, A Huutoniemi, M Partinen, and T Hokfelt. Narcolepsy patients have antibodies that stain distinct cell populations in rat brain and influence sleep patterns. PNAS, 111(35):E3735-E3744, September 2014.

[120] Vesna Cvetkovic-Lopes, Laurence Bayer, Stéphane Dorsaz, Stéphanie Maret, Sylvain Pradervand, Yves Dauvilliers, Michel Lecendreux, Gert-Jan Lammers, Claire E H M Donjacour, Renaud A Du Pasquier, Corinne Pfister, Brice Petit, Hyun Hor, Michel Mühlethaler, and Mehdi Tafti. Elevated Tribbles homolog 2-specific antibody levels in narcolepsy patients. Journal of Clinical Investigation, 120(3):713-719, March 2010.

[121] Susumu Tanaka, Yutaka Honda, Yuichi Inoue, and Makoto Honda. Detection of Autoantibodies Against Hypocretin, hcrtr1, and hcrtr2 in Narcolepsy: Anti-Hcrt System Antibody in Narcolepsy. Sleep, 29(5):633-638, April 2006. 
[122] Aude Deloumeau, Sophie Bayard, Quentin Coquerel, Pierre Déchelotte, Christine Bole-Feysot, Bertrand Carlander, Valérie Cochen De Cock, Sergueï O Fetissov, and Yves Dauvilliers. Increased Immune Complexes of Hypocretin Autoantibodies in Narcolepsy. PLoS ONE, 5(10):e13320, October 2010.

[123] D Galimberti and E Scarpini, editors. Neurodegenerative diseases - Clinical Aspects, Molecular Genetics and Biomarkers. Springer.

[124] Xiaojie Zhang and Weihong Song. The role of APP and BACE1 trafficking in APP processing and amyloid- $\beta$ generation. Alzheimer's Research \& Therapy, 5(46):1-8, August 2013.

[125] Jin-Jing Pei, Magnus Sjögren, and Bengt Winblad. Neurofibrillary degeneration in AlzheimerE $\frac{1}{4} \mathrm{~s}$ disease: from molecular mechanisms to identification of drug targets. Current Opinion in Psychiatry, 21(6):555-561, November 2008.

[126] Orestes V Forlenza, Breno S Diniz, Antonio L Teixeira, Florindo Stella, and Wagner Gattaz. Mild cognitive impairment (part 2): biological markers fordiagnosis and prediction of dementia in Alzheimer'sdisease. Revista Brasileira de Psiquiatria, 35(3):284-294, 2013.

[127] Ronald C Petersen, O Roberts Rosebud, David S Knopman, Bradley F Boeve, Yonas E Geda, Robert J Ivnik, Glenn E Smith, and Clifford R Jack, Jr. Mild Cognitive Impairment. Arch Neurol., 66(12):1477-1455, November 2009.

[128] William I Rosenblum. Neurobiology of Aging. Neurobiology of Aging, 35(5):969-974, May 2014.

[129] Marilyn S Albert, Steven T DeKosky, Dennis Dickson, Bruno Dubois, Howard H Feldman, Nick C Fox, Anthony Gamst, David M Holtzman, William J Jagust, Ronald C Petersen, Peter J Snyder, Maria C Carrillo, Bill Thies, and Creighton H Phelps. The diagnosis of mild cognitive impairment due to Alzheimer's disease: Recommendations from the National Institute on Aging and Alzheimer's Association workgroup. Alzheimer's and Dementia, pages 1-10, April 2011.

[130] Guy M McKhann, David S Knopman, Howard Chertkow, Bradley T Hyman, Clifford R Jack, Jr, Claudia H Kawas, William E Klunk, Walter J Koroshetz, Jennifer J Manly, Richard Mayeux, Richard C Mohs, John C Morris, Martin N Rossor, Philip Scheltens, Maria C Carillo, Bill Thies, Sandra Weintraub, and Creighton H Phelps. The diagnosis of dementia due to Alzheimer's disease: Recommendations from the National Institute on Aging and the Alzheimer's Association workgroup. Alzheimer's and Dementia, pages 1-7, April 2011.

[131] Q Wang. Proteomic analysis of neurofibrillary tangles in Alzheimer disease identifies GAPDH as a detergent-insoluble paired helical filament tau binding protein. The FASEB Journal, February 2005.

[132] L Liao, D Cheng, J Wang, D M Duong, T G Losik, M Gearing, H D Rees, J J Lah, A I Levey, and J Peng. Proteomic Characterization of Postmortem Amyloid Plaques Isolated by Laser Capture Microdissection. Journal of Biological Chemistry, 279(35):37061-37068, August 2004.

[133] Petra Zürbig and Holger Jahn. Use of proteomic methods in the analysis of human body fluids in Alzheimer research. ELECTROPHORESIS, 33(24):3617-3630, December 2012.

[134] Simone Lista, Frank Faltraco, David Prvulovic, and Harald Hampel. Progress in Neurobiology. Progress in Neurobiology, 101-102:1-17, February 2013.

[135] Steven J Kiddle, Martina Sattlecker, Petroula Proitsi, Andrew Simmons, Eric Westman, Chantal Bazenet, Sally Nelson, Stephen Williams, Angela Hodges, Caroline Johnston, Hilkka Soininen, Iwona Kłoszewska, Patrizia Mecocci, Magda Tsolaki, Bruno Vellas, Stephen Newhouse, Simon Lovestone, and Richard J B Dobson. Candidate Blood Proteome Markers of Alzheimer's Disease Onset and Progression: A Systematic Review and Replication Study. Journal of Alzheimer's Disease, 38:515-531, November 2013.

[136] A H Simonsen, J McGuire, V N Podust, H Davies, L Minthon, I Skoog, N Andreasen, A Wallin, G Waldemar, and K Blennow. Identification of a novel panel of cerebrospinal fluid biomarkers for Alzheimer's disease. Neurobiology of Aging, 29(7):961-968, July 2008.

[137] Tania Colasanti, Cristiana Barbati, Giuseppe Rosano, Walter Malorni, and Elena Ortona. Autoimmunity Reviews. Autoimmunity Reviews, 9(12):807-811, October 2010.

[138] Eric Nagele, Min Han, Cassandra DeMarshall, Benjamin Belinka, and Robert Nagele. Diagnosis of Alzheimer's Disease Based on Disease-Specific Autoantibody Profiles in Human Sera. PLoS ONE, 6(8):e23112, August 2011.

[139] Andrew J Lees, John Hardy, and Tamas Revesz. Parkinson's disease. The Lancet, 373(9680):2055-2066, June 2009. 
[140] Chadwick W Christine and Michael J Aminoff. Clinical differentiation of parkinsonian syndromes: Prognostic and therapeutic relevance. The American Journal of Medicine, 117(6):412-419, September 2004.

[141] D J Gelb, E Oliver, and S Gilman. Diagnostic Criteria for Parkinson Disease. Arch Neurol., 56(1):33-39, November 1999.

[142] Brit Mollenhauer, Omar MA El-Agnaf, Katrin Marcus, Claudia Trenkwalder, and Michael G Schlossmacher. Quantification of $\alpha$-synuclein in cerebrospinal fluid as a biomarker candidate: review of the literature and considerations for future studies. Biomarkers in Medicine, 4(5):683-699, October 2010.

[143] James B Leverenz, Imran Umar, Qing Wang, Thomas J Montine, Pamela J McMillan, Debby W Tsuang, Jinghua Jin, Catherine Pan, Jenny Shin, David Zhu, and Jing Zhang. Proteomic Identification of Novel Proteins in Cortical Lewy Bodies. Brain Pathology, 17(2):139-145, April 2007.

[144] Lama M Chahine, Matthew B Stern, and Alice Chen-Plotkin. Parkinsonism and Related Disorders. Parkinsonism and realted Disorders, 20(S1):S99-S103, November 2013.

[145] Judy K Qiang, Yvette C Wong, Andrew Siderowf, Howard I Hurtig, Sharon X Xie, Virginia M Y Lee, John Q Trojanowski, Dora Yearout, James B Leverenz, Thomas J Montine, Matt Stern, Susan Mendick, Danna Jennings, Cyrus Zabetian, Ken Marek, and Alice S Chen-Plotkin. Plasma apolipoprotein A1 as a biomarker for Parkinson disease. Annals of Neurology, 74(1):119-127, August 2013.

[146] Alice S Chen-Plotkin, William T Hu, Andrew Siderowf, Daniel Weintraub, Rachel Goldmann Gross, Howard I Hurtig, Sharon X Xie, Steven E Arnold, Murray Grossman, Christopher M Clark, Leslie M Shaw, Leo McCluskey, Lauren Elman, Vivianna M Van Deerlin, Virginia M Y Lee, Holly Soares, and John Q Trojanowski. Plasma epidermal growth factor levels predict cognitive decline in Parkinson disease. Annals of Neurology, 69(4):655-663, November 2010.

[147] Fadi Abdia, Joseph F Quinnb, Joseph Jankovicc, Martin McIntoshd, James B Leverenze, Elaine Peskinde, Randy Nixonb, John Nuttb, Katherine Chungb, Cyrus Zabetiane, Ali Samiie, Melanie Lina, Stephen Hattana, Catherine Pane, Yan Wange, Jinghua Jine, David Zhue, G Jane Lie, Yan Liud, Dana Waichunasb, Thomas J Montinee, and Jing Zhang. Detection of biomarkers with a multiplex quantitative proteomic platform in cerebrospinal fluid of patients with neurodegenerative disorders. Journal of Alzheimer's Disease, 9:293-348, July 2006.

[148] Brit Mollenhauer and Claudia Trenkwalder. Neurochemical biomarkers in the differential diagnosis of movement disorders. Movement Disorders, 24(10):1411-1426, July 2009.

[149] Shengdi Chen, Weidong D Le, Wenjie J Xie, Maria E Alexianu, Joseph I Engelhardt, László Siklós, and Stanley H Appel. Experimental Destruction of Substantia Nigra Initiated by Parkinson Disease Immunoglobulins. Arch Neurol., 55:1075-1080, April 1998.

[150] Min Han, Eric Nagele, Cassandra DeMarshall, Nimish Acharya, and Robert Nagele. Diagnosis of Parkinson's Disease Based on Disease-Specific Autoantibody Profiles in Human Sera. PLoS ONE, 7(2):e32383, February 2012.

[151] Uwe-Karsten Hanisch and Helmut Kettenmann. Microglia: active sensor and versatile effector cells in the normal and pathologic brain. Nature Neuroscience, 10(11):1387-1394, November 2007.

[152] Divya Sagar, Catherine Foss, Rasha El Baz, Martin G Pomper, Zafar K Khan, and Pooja Jain. Mechanisms of Dendritic Cell Trafficking Across the Blood-brain Barrier. Journal of Neuroimmune Pharmacology, 7(1):74-94, August 2011.

[153] Minesh Kapadia and Boris Sakic. Progress in Neurobiology. Progress in Neurobiology, 95(3):301-333, November 2011.

[154] Charlotte E Teunissen, Christine Dijkstra, and Chris Polman. Biological markers in CSF and blood for axonal degeneration in multiple sclerosis. Lancet Neurology, 4:32-41, April 2005.

[155] C E Teunissen and M Khalil. Neurofilaments as biomarkers in multiple sclerosis. Multiple Sclerosis Journal, 18(5):552556, April 2012.

[156] A C Kroksveen, J A Opsahl, T T Aye, R J Ulvik, and F S Berven. Proteomics of human cerebrospinal fluid: Discovery and verification of biomarker candidates in neurodegenerative diseases using quantitative proteomics. Journal of Proteomics, 74(4):371-388, April 2011.

[157] Bruce D Trapp and Klaus-Armin Nave. Multiple Sclerosis: An Immune or Neurodegenerative Disorder? Annual Review of Neuroscience, 31(1):247-269, July 2008. 
[158] Sandra Amor, Laura A N Peferoen, Daphne Y S Vogel, Marjolein Breur, Paul van der Valk, David Baker, and Johannes M van Noort. Inflammation in neurodegenerative diseases - an update. Immunology, 142(2):151-166, April 2014.

[159] Suhayl Dhib-Jalbut, Douglas L Arnold, Don W Cleveland, Mark Fisher, Robert M Friedlander, M Maral Mouradian, Serge Przedborski, Bruce D Trapp, Tony Wyss-Coray, and V Wee Yong. Neurodegeneration and neuroprotection in multiple sclerosis and other neurodegenerative diseases. Journal of Neuroimmunology, 176(1-2):198-215, July 2006.

[160] J M Frischer, S Bramow, A Dal-Bianco, C F Lucchinetti, H Rauschka, M Schmidbauer, H Laursen, P S Sorensen, and $\mathrm{H}$ Lassmann. The relation between inflammation and neurodegeneration in multiple sclerosis brains. Brain, 132(5):1175-1189, May 2009.

[161] A A Tveita. The danger model in deciphering autoimmunity. Rheumatology, 49(4):632-639, March 2010.

[162] P Matzinger. The Danger Model: A Renewed Sense of Self. Science, 296(5566):301-305, April 2002.

[163] Klaartje Somers, Cindy Govarts, Piet Stinissen, and Veerle Somers. Multiplexing approaches for autoantibody profiling in multiple sclerosis. Autoimmunity Reviews, 8(7):573-579, June 2009.

[164] Mireia Sospedra and Roland Martin. IMMUNOLOGY OF MULTIPLE SCLEROSIS*. Annual Review of Immunology, 23(1):683-747, April 2005.

[165] C Teunissen, T Menge, A Altintas, J C Alvarez-Cermeno, A Bertolotto, F S Berven, L Brundin, M Comabella, M Degn, F Deisenhammer, F Fazekas, D Franciotta, J L Frederiksen, D Galimberti, S Gnanapavan, H Hegen, B Hemmer, R Hintzen, S Hughes, E Iacobaeus, A C Kroksveen, J Kuhle, J Richert, H Tumani, L M Villar, J Drulovic, I Dujmovic, M Khalil, and A Bartos. Consensus definitions and application guidelines for control groups in cerebrospinal fluid biomarker studies in multiple sclerosis. Multiple Sclerosis Journal, 19(13):1802-1809, November 2013.

[166] Andrew J Percy, Andrew G Chambers, Derek S Smith, and Christoph H Borchers. Standardized Protocols for Quality Control of MRM-based Plasma Proteomic Workflows. Journal of Proteome Research, 12(1):222-233, January 2013.

[167] Andrew J Percy, Carol E Parker, and Christoph H Borchers. Pre-analytical and analytical variability in absolute quantitative MRM-based plasma proteomic studies. Bioanalysis, 5(22):2837-2856, November 2013.

[168] Simone Lista, Frank Faltraco, and Harald Hampel. Progress in Neurobiology. Progress in Neurobiology, 101-102:18-34, January 2013.

[169] Sen-Yung Hsieh, Ren-Kung Chen, Yi-Hsin Pan, and Hai-Lun Lee. Systematical evaluation of the effects of sample collection procedures on low-molecular-weight serum/plasma proteome profiling. PROTEOMICS, 6(10):3189-3198, May 2006.

[170] Lisa J Zimmerman, Ming Li, Wendell G Yarbrough, Robbert J C Slebos, and Daniel C Liebler. Global Stability of Plasma Proteomes for Mass Spectrometry-Based Analyses*. Molecular \& Cellular Proteomics, 6(11):1-12, June 2012.

[171] Ulrika Qundos, Mun-Gwan Hong, Gunnel Tybring, Mark Divers, Jacob Odeberg, Mathias Uhlén, Peter Nilsson, and Jochen M Schwenk. Profiling post-centrifugation delay of serum and plasma with antibody bead arrays. Journal of Proteomics, pages 1-9, May 2013.

[172] B Ayoglu, A Chaouch, H Lochmuller, L Politano, E Bertini, P Spitali, M Hiller, E H Niks, F Gualandi, F Ponten, K Bushby, A Aartsma-Rus, E Schwartz, Y Le Priol, V Straub, M Uhlen, S Cirak, P A C 't Hoen, F Muntoni, A Ferlini, J M Schwenk, P Nilsson, and C Al-Khalili Szigyarto. Affinity proteomics within rare diseases: a BIO-NMD study for blood biomarkers of muscular dystrophies. EMBO Molecular Medicine, 6(7):918-936, July 2014.

[173] Genoveva C E Keustermans, Sanne B E Hoeks, Jenny M Meerding, Berent J Prakken, and Wilco de Jager. Cytokine assays: An assessment of the preparation and treatment of blood and tissue samples. Methods, 61(1):10-17, May 2013.

[174] Jochen M Schwenk, Ulrika Igel, Bernet S Kato, George Nicholson, Fredrik Karpe, Mathias Uhlén, and Peter Nilsson. Comparative protein profiling of serum and plasma using an antibody suspension bead array approach. PROTEOMICS, 10(3):532-540, February 2010.

[175] Frode S Berven, Ann C Kroksveen, Magnus Berle, Tarja Rajalahti, Kristian Flikka, Reidar Arneberg, Kjell-Morten Myhr, Christian Vedeler, Olav M Kvalheim, and Rune J Ulvik. Pre-analytical influence on the low molecular weight cerebrospinal fluid proteome. PROTEOMICS - Clinical Applications, 1(7):699-711, July 2007. 
[176] Anja H Simonsen, Justyna M C Bahl, Pia B Danborg, Veronica Lindstrom, Severin O Larsen, Anders Grubb, Niels H H Heegaard, and Gunhild Waldemar. Journal of Neuroscience Methods. Journal of Neuroscience Methods, 215(2):234240, May 2013.

[177] Viviana Greco, Damiana Pieragostino, Cristian Piras, Ruedi Aebersold, Jens Wiltfang, Carlo Caltagirone, Sergio Bernardini, and Andrea Urbani. Direct analytical sample quality assessment for biomarker investigation: Qualifying cerebrospinal fluid samples. PROTEOMICS, 14:1954-1962, September 2014.

[178] Johan Malm, Thomas E Fehniger, Pia Danmyr, Ákos Végvári, Charlotte Welinder, Henrik Lindberg, Roger Appelqvist, Karin Sjödin, Elisabet Wieslander, Thomas Laurell, Sophia Hober, Frode S Berven, David Fenyö, Xiangdong Wang, Per E Andrén, Goutham Edula, Elisabet Carlsohn, Manuel Fuentes, Carol L Nilsson, Magnus Dahlbäck, Melinda Rezeli, David Erlinge, and György Marko-Varga. ScienceDirect. Journal of Proteomics, 95(C):38-45, December 2013.

[179] Sabine Lehmann, Fiorella Guadagni, Helen Moore, Garry Ashton, Michael Barnes, Erica Benson, Judith Clements, Iren Koppandi, Domenico Coppola, Sara Yasemin Demiroglu, Yvonne DeSouza, Annemieke De Wilde, Jacko Duker, James Eliason, Barbara Glazer, Keith Harding, Jae Pil Jeon, Joseph Kessler, Theresa Kokkat, Umberto Nanni, Kathi Shea, Amy Skubitz, Stella Somiari, Gunnel Tybring, Elaine Gunter, and Fotini Betsou International Society for B. Standard Preanalytical Coding for Biospecimens: Review and Implementation of the Sample PREanalytical Code (SPREC). Biopreservation and Biobanking, 10(4):366-374, August 2012.

[180] Maria Pernemalm, Rolf Lewensohn, and Janne Lehtiö. Affinity prefractionation for MS-based plasma proteomics. PROTEOMICS, 9(6):1420-1427, March 2009.

[181] Elisa Bellei, Stefania Bergamini, Emanuela Monari, Luca Isaia Fantoni, Aurora Cuoghi, Tomris Ozben, and Aldo Tomasi. High-abundance proteins depletion for serum proteomic analysis: concomitant removal of non-targeted proteins. Amino Acids, 40(1):145-156, May 2010.

[182] Jill Granger, Javed Siddiqui, Shannon Copeland, and Daniel Remick. Albumin depletion of human plasma also removes low abundance proteins including the cytokines. PROTEOMICS, 5(18):4713-4718, December 2005.

[183] Mao Peng, Nadia Taouatas, Salvatore Cappadona, Bas van Breukelen, Shabaz Mohammed, Arjen Scholten, and Albert J R Heck. correspondence. Nature Methods, 9(6):524-525, June 2012.

[184] R G Biringer. Enhanced sequence coverage of proteins in human cerebrospinal fluid using multiple enzymatic digestion and linear ion trap LC-MS/MS. Briefings in Functional Genomics and Proteomics, 5(2):144-153, May 2006.

[185] Jochen M Schwenk, Ulrika Igel, Maja Neiman, Hanno Langen, Charlotte Becker, Anders Bjartell, Fredrik Ponten, Fredrik Wiklund, Henrik Gro nberg, Peter Nilsson, and Mathias Uhlen. Toward Next Generation Plasma Profiling via Heat-induced Epitope Retrieval and Array-based Assays. Molecular \& Cellular Proteomics, 11(9):1-11, October 2010.

[186] Maja Neiman, Claudia Fredolini, Henrik Johansson, Janne Lehtiö, Per-Åke Nygren, Mathias Uhlén, Peter Nilsson, and Jochen M Schwenk. Selectivity analysis of single binder assays used in plasma protein profiling. PROTEOMICS, 13(23-24):3406-3410, November 2013.

[187] Andrew J Percy, Andrew G Chambers, Juncong Yang, and Christoph H Borchers. Multiplexed MRM-based quantitation of candidate cancer biomarker proteins in undepleted and non-enriched human plasma. PROTEOMICS, 13(14):2202-2215, June 2013.

[188] Nils A Kulak, Garwin Pichler, Igor Paron, Nagarjuna Nagaraj, and Matthias Mann. Minimal, encapsulated proteomicsample processing applied to copy-number estimation in eukaryotic cells. Nature Methods, 11(3):319-324, February 2014.

[189] Hasmik Keshishian, Terri Addona, Michael Burgess, Eric Kuhn, and Steven A Carr. Quantitative, Multiplexed Assays for Low Abundance Proteins in Plasma by Targeted Mass Spectrometry and Stable Isotope Dilution. Molecular \& Cellular Proteomics, 6(12):1-31, December 2007.

[190] Tujin Shi, Xuefei Sun, Yuqian Gao, Thomas L Fillmore, Athena A Schepmoes, Rui Zhao, Jintang He, Ronald J Moore, Jacob Kagan, Karin D Rodland, Tao Liu, Alvin Y Liu, Richard D Smith, Keqi Tang, David G Camp, II, and Wei-Jun Qian. Targeted Quantification of Low $\mathrm{ng} / \mathrm{mL}$ Level Proteins in Human Serum without Immunoaffinity Depletion. Journal of Proteome Research, 12(7):3353-3361, July 2013. 
[191] Kristin R Wildsmith, Stephen P Schauer, Ashley M Smith, David Arnott, Yuda Zhu, Joshua Haznedar, Surinder Kaur, W Rodney Mathews, and Lee A Honigberg. Identification of longitudinally dynamic biomarkers in Alzheimer's disease cerebrospinalfluid by targeted proteomics. Molecular Neurodegeneration, 9(22):1-14, June 2014.

[192] Jeremy Jeudy, Arnaud Salvador, Romain Simon, Aurore Jaffuel, Catherine Fonbonne, Jean-François Léonard, JeanCharles Gautier, Olivier Pasquier, and Jerome Lemoine. Overcoming biofluid protein complexity during targeted mass spectrometry detection and quantification of protein biomarkers by MRM cubed (MRM3). Analytical and Bioanalytical Chemistry, 406(4):1193-1200, August 2013.

[193] Andrew J Percy, Juncong Yang, Andrew G Chambers, Romain Simon, Darryl B Hardie, and Christoph H Borchers. Multiplexed MRM with Internal Standards for Cerebrospinal Fluid Candidate Protein Biomarker Quantitation. Journal of Proteome Research, 13(8):3733-3747, August 2014.

[194] Ulf Landegren, Johan Vänelid, Maria Hammond, Rachel Yuan Nong, Di Wu, Erik Ullerås, and Masood KamaliMoghaddam. Opportunities for Sensitive Plasma Proteome Analysis. Analytical Chemistry, 84(4):1824-1830, February 2012.

[195] David M Rissin, David R Fournier, Tomasz Piech, Cheuk W Kan, Todd G Campbell, Linan Song, Lei Chang, Andrew J Rivnak, Purvish P Patel, Gail K Provuncher, Evan P Ferrell, Stuart C Howes, Brian A Pink, Kaitlin A Minnehan, David H Wilson, and David C Duffy. Simultaneous Detection of Single Molecules and Singulated Ensembles of Molecules Enables Immunoassays with Broad Dynamic Range. Analytical Chemistry, 83(6):2279-2285, March 2011.

[196] J Todd, B Freese, A Lu, D Held, J Morey, R Livingston, and P Goix. Ultrasensitive Flow-based Immunoassays Using Single-Molecule Counting. Clinical Chemistry, 53(11):1990-1995, September 2007.

[197] Z W Lai, A Petrera, and O Schilling. The emerging role of the peptidome in biomarker discovery and degradome profiling. Biological Chemistry, [Epub ahead of print]:1-17, September 2014.

[198] Mikko Hölttä, Henrik Zetterberg, Ekaterina Mirgorodskaya, Niklas Mattsson, Kaj Blennow, and Johan Gobom. Peptidome Analysis of Cerebrospinal Fluid by LC-MALDI MS. PLoS ONE, 7(8):e42555, August 2012.

[199] Maria Infantino, Mariangela Manfredi, Francesca Meacci, Piercarlo Sarzi-Puttini, Cristian Ricci, Fabiola Atzeni, and Maurizio Benucci. Clinica Chimica Acta. Clinica Chimica Acta, 436(C):237-242, September 2014.

[200] H Alexopoulos, E I Kampylafka, I Chatzi, M Travasarou, K E Karageorgiou, M C Dalakas, and A G Tzioufas. Journal of Neuroimmunology. Journal of Neuroimmunology, 260(1-2):117-120, July 2013.

[201] Permphan Dharmasaroja. Specificity of autoantibodies to epitopes of myelin proteins in multiple sclerosis. Journal of the Neurological Sciences, (206):7-16, January 2003.

[202] Barbara Hjelm, Björn Forsström, Ulrika Igel, Henrik Johannesson, Charlotte Stadler, Emma Lundberg, Fredrik Ponten, Anna Sjöberg, Johan Rockberg, Jochen M Schwenk, Peter Nilsson, Christine Johansson, and Mathias Uhlén. Generation of monospecific antibodies based on affinity capture of polyclonal antibodies. Protein Science, 20(11):1824-1835, October 2011.

[203] Björn Forsström, B Bislawska Axnäs, K P Stengele, J Bühler, T J Albert, T A Richmond, F J Hu, P Nilsson, E P Hudson, Johan Rockberg, and M Uhlen. Proteome-wide Epitope Mapping of Antibodies Using Ultra-dense Peptide Arrays*. Molecular 8$\}$ Cellular Proteomics, 13(6):1585-1597, May 2014.

[204] Stefan Enroth, Aring sa Johansson, Sofia Bosdotter Enroth, and Ulf Gyllensten. Strong effects of genetic and lifestyle factors on biomarker variation and use of personalized cutoffs. Nature Communications, 5:1-11, 1.

[205] David Melzer, John R B Perry, Dena Hernandez, Anna-Maria Corsi, Kara Stevens, Ian Rafferty, Fulvio Lauretani, Anna Murray, J Raphael Gibbs, Giuseppe Paolisso, Sajjad Rafiq, Javier Simon-Sanchez, Hana Lango, Sonja Scholz, Michael N Weedon, Sampath Arepalli, Neil Rice, Nicole Washecka, Alison Hurst, Angela Britton, William Henley, Joyce van de Leemput, Rongling Li, Anne B Newman, Greg Tranah, Tamara Harris, Vijay Panicker, Colin Dayan, Amanda Bennett, Mark I McCarthy, Aimo Ruokonen, Marjo-Riitta Jarvelin, Jack Guralnik, Stefania Bandinelli, Timothy M Frayling, Andrew Singleton, and Luigi Ferrucci. A Genome-Wide Association Study Identifies Protein Quantitative Trait Loci (pQTLs). PLoS Genetics, 4(5):e1000072, May 2008.

[206] A Lourdusamy, S Newhouse, K Lunnon, P Proitsi, J Powell, A Hodges, S K Nelson, A Stewart, S Williams, I Kloszewska, P Mecocci, H Soininen, M Tsolaki, B Vellas, S Lovestone, on behalf of the AddNeuroMed Consortium, R Dobson, 
and for the Alzheimer's Disease Neuroimaging Initiative. Identification of cis-regulatory variation influencing protein abundance levels in human plasma. Human Molecular Genetics, 21(16):3719-3726, July 2012.

[207] R A Kay. TCR GENE POLYMORPHISMS AND AUTOIMMUNE DISEASE. European Journal ofImmunogenerics, 23:159-177, September 2006.

[208] Jose Vina, Juan Gambini, Raul Lopez-Grueso, Khira M Abdelaziz, Mariona Jove, and Consuelo Borras. Females Live Longer than Males: Role of Oxidative Stress. Current Pharmaceutical Design,, 17:3959-3965, November 2011.

[209] Roksana Khalid. Immunology Letters. Immunology Letters, 162(1):223-232, November 2014.

[210] S T Ngo, F J Steyn, and P A McCombe. Frontiers in Neuroendocrinology. Frontiers in Neuroendocrinology, 35(3):347369, August 2014.

[211] Jeffrey J Stewart. The female X-inactivation mosaic insystemic lupus erythematosus. Immunology Today, 19(8):352357, July 1998.

[212] Ivy N Miller and Alice Cronin-Golomb. Gender differences in Parkinson's disease: Clinical characteristics and cognition. Movement Disorders, 25(16):2695-2703, October 2010.

[213] Anders M Fjell and Kristine B Walhovd. Structural Brain Changes in Aging: Courses, Causes and CognitiveConsequences. Reviews in the Neurosciences, 21:187-221, March 2010.

[214] SUZANNE KUNICKI, JOHN RICHARDSON, PANKAJ D MEHTA, KWANG S KIM, and EDITH ZORYCHTA. The Effects of Age, Apolipoprotein E Phenotype and Gender on the Concentration of Amyloid-beta (Abeta) 40, Abeta42, Apolipoprotein E and Transthyretin in Human Cerebrospinal Fluid. Clinical Biochemistry, 31(5):409-415, July 1998.

[215] G S Baird, S K Nelson, T R Keeney, A Stewart, S Williams, S Kraemer, E R Peskind, and T J Montine. Age-Dependent Changes in the Cerebrospinal Fluid Proteome by Slow Off-Rate Modified Aptamer Array. AJPA, 180(2):446-456, February 2012.

[216] Clifford R Jack, David S Knopman, William J Jagust, Leslie M Shaw, Paul S Aisen, Michael W Weiner, Ronald C Petersen, and John Q Trojanowski. Hypothetical model of dynamic biomarkers of the Alzheimer's pathological cascade. The Lancet Neurology, 9(1):119-128, January 2010.

[217] Mathias Uhlén, Per Oksvold, Linn Fagerberg, Emma Lundberg, Kalle Jonasson, Mattias Forsberg, Martin Zwahlen, Caroline Kampf, Kenneth Wester, Sophia Hober, Henrik Wernerus, Lisa Björling, and Fredrik Ponten. Towards a knowledge-based Human Protein Atlas. Nature Publishing Group, 28(12):1248-1250, December 2010. 